ISSN : 1693.1041

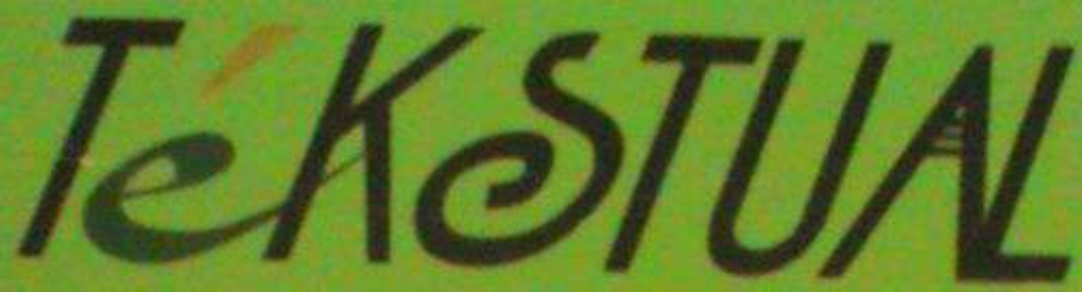

Finat Plmiah Enambutanan

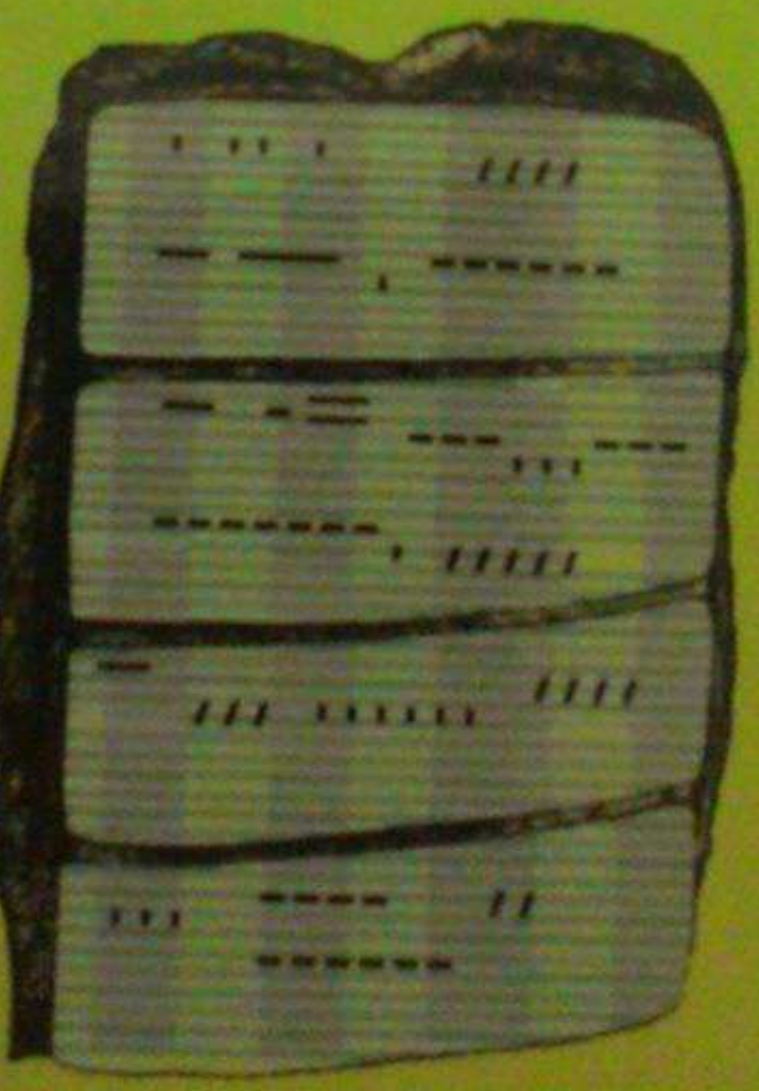




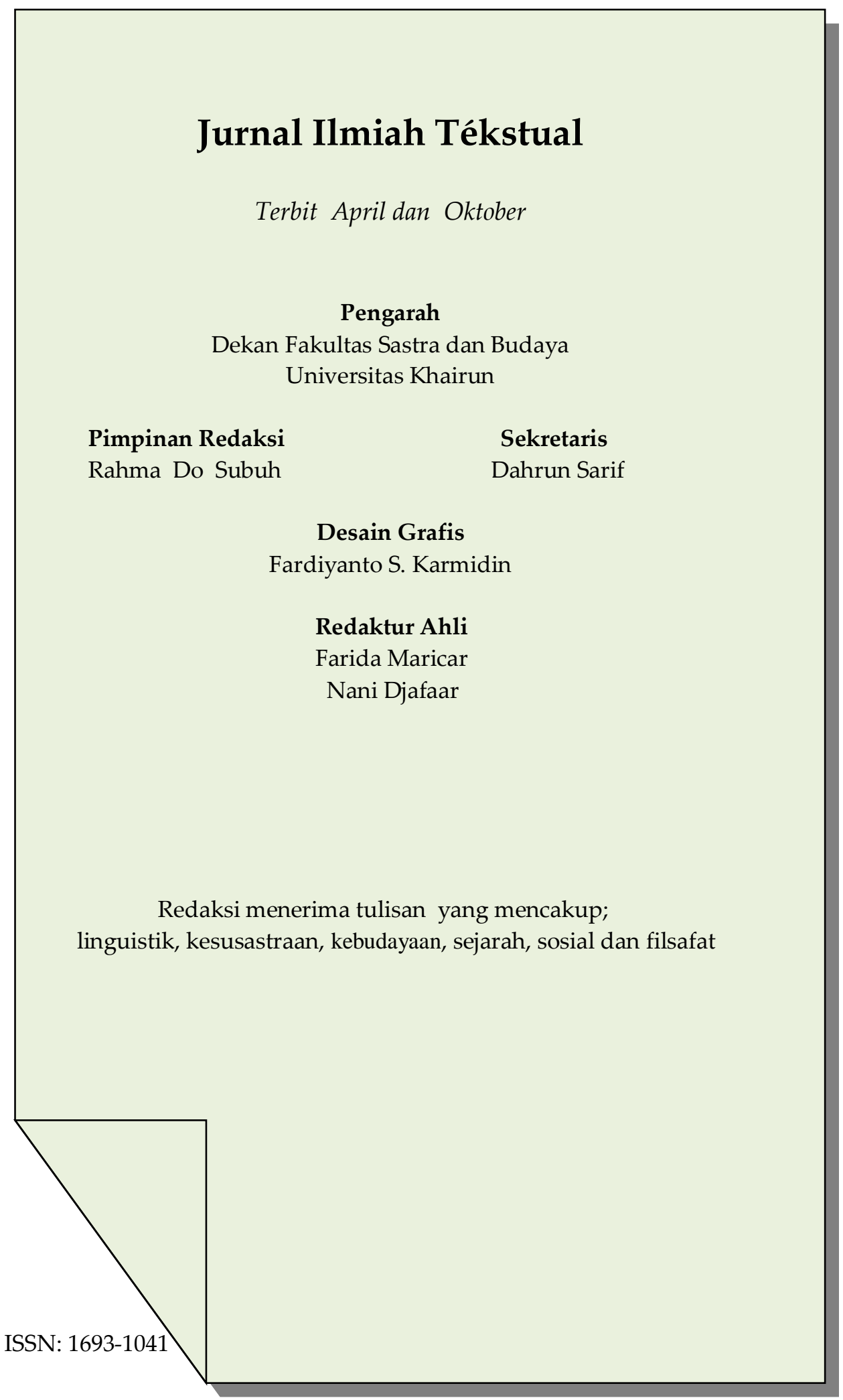




\section{PENGANTAR REDAKSI}

Salam Pembaca,

Mengawali tahun 2017 ini, jurnal tekstual menghadirkan enam tulisan dari para pengajar baik dalam lingkup fakultas sastra dan budaya sendiri, juga pengajar dari universitas lainnya. Adapun keenam tulisan yang terdapat dalam edisi April ini antara lain dari Akhirudin, seorang pengajar dari STIKIP Mega Recky Makassar, yang membahas tentang belajar kelompok dalam pelajaran sosiologi sebagai satu strategi agar siswa dapat berinteraksi dalam kelas. Tulisan kedua dari Asep Saiful Bahri tentang hubungan identitas sosial dengan kompetensi professional pada guru-guru IPS di Rawalumbu Kecamatan Bekasi. Betly Taghulihi, pengajar pada fakultas sastra dan budaya menulis tentang strategi pengembangan wisata bahari di pulau Morotai. Tulisan selanjutnya dari Nirwana yang membahas tentang analisis bahasa pada berbagai iklan yang ditayangkan pada media elektronik. Tulisan kelima dari Rahma Do Subuh, yang menulis tentang kebudayaan bangsa Cina yang pernah mendiami pulau Ternate. Ada beberapa atraksi/ritual budaya yang berpotensi untuk menarik wisatawan jika dimunculkan kembali. Rahma Djumati, membahas tentang keberadaan naskah-naskah kuno yang masih tersimpan di kesultanan Ternate dan Tidore melalui tinjauan filologi. Tulisan terakhir dari Sunaidin Ode Mulae yang menulis tentang sikap pejabat senior universitas Khairun dan universitas Muhammadiyah terhadap bahasa Inggris, dalam upaya mendorong kampus yang bertaraf internasional. 


\section{Petunjuk Singkat}

Tékstual adalah jurnal yang berorientasi pada ilmu-ilmu humaniora yang mencakup linguistik kesusastraan, sejarah, antropologi, filsafat, agama, dan seni. Ada tiga jenis artikel yang dimuat dalam jurnal ini: (1) artikel hasil penelitian, (2) artikel reproduksi teori (artikel konseptual), dan (3) timbangan buku.

Artikel hasil penelitian memuat unsur-unsur:

1. Judul

2. Nama Penulis

3. Abstrak (dan kata kunci)

4. Pendahuluan

5. Metode

6. Pembahasan

7. Simpulan

8. Daftar Pustaka

Artikel reproduksi teori memuat unsur-unsur:
1. Judul
2. Nama Penulis
3. Abstrak (dan kata kunci)
4. Pendahuluan
5. Pembahasan
6. Rangkuman/Penutup
7. Daftar Pustaka

Timbangan buku memuat unsur-unsur:

1. Judul buku (tahun penerbitan, nama penerbit, jumlah halaman).

2. Isi (1) posisi buku: baru, pengulangan, pengembangan, dan (2) penilaian: kelebihan dan kekurangan buku yang ditimbang, misalnya isi, gaya bahasa, dan cara penyajian.

3. Simpulan.

Redaksi Tékstual menerima artikel hasil penelitian, reproduksi teori, dan timbangan buku dengan syarat-syarat sebagai berikut:

1. Artikel harus asli dan belum pernah dimuat di media cetak.

2. Artikel ditulis dengan bahasa Indonesia dengan abstrak bahasa Inggris/bahasa asing lainnya atau dengan bahasa Inggris dengan abstrak bahasa Indonesia.

3. Nama penulis dan alamat atau lembaga tempat bekerja ditulis di bawah judul.

4. Keterangan singkat tentang penulis atau artikelnya ditulis sebagai catatan pada halaman terakhir.

5. Tabel dan gambar diberikan keterangan yang jelas.

6. Semua rujukan (kutipan) harus ada dalam daftar pustaka.

7. Artikel diketik dengan komputer, memakai program Micosoft Word atau sejenisnya dengan huruf standar Times New roman 12 atau Arial 12 dengan jarak baris satu setengah spasi.

8. Panjang artikel maksimal 15 halaman,uk.A4 termasuk daftar pustaka dan lampirannya.

9. Artikel dikirim ke Redaksi Tékstual paling lambat satu bulan sebelum penerbitan, yaitu April dan Oktober.

10. Artikel yang dimuat akan mendapatkan imbalan berupa bukti penerbitan 1(satu) eksemplar .

11. Kepastian pemuatan atau penolakan artikel akan disampaikan secara tertulis.

Alamat Redaksi: Kampus II Gambesi Universitas Khairun

Jln. Pertamina, Ternate Selatan

e-mail: jurnalsastra63@gmail.com

ISSN: 1693-1041 


\section{DAFTAR ISI}

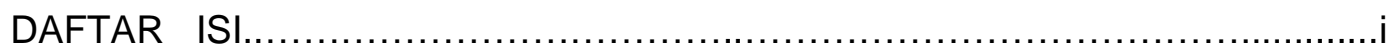

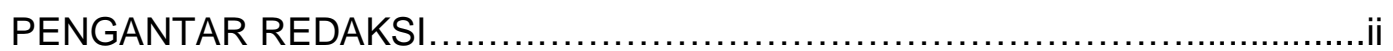

PENGARUH KEMAMPUAN BERINTERAKSI SISWA DALAM BELAJAR KELOMPOK TERHADAP PRESTASI BELAJAR SOSIOLOGI SISWA KELAS XI SMA TUNAS BANGSA MAKASSAR

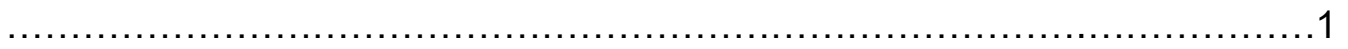

Akhiruddin

STRATEGI PENGEMBANGAN WISATA BAHARI KABUPATEN MOROTAI PROVINSI MALUKU

UTARA. .26

Betly Taghulihi

ANALISIS PENGGUNAAN BAHASA INDONESIA RAGAM IKLAN PADA MEDIA DAN ELEKTRONIK..........................................46 Nirwana

IDENTIFIKASI BUDAYA CINA POTENSI WISATA BUDAYA PENUNJANG PARIWISATA TERNATE. .59

\section{Rahma Do Subuh}

PENELUSURAN NASKAH KUNO di KESULTANAN TERNATE DAN TIDORE (TINJAUAN FILOLOGI). .82

\section{Rahma Djumati}

Sikap Pejabat Senior Universitas Khairun Dan Universitas Muhammadiyah Maluku Utara Terhadap Bahasa Inggris, Upaya Mendorong Kampus Bertaraf International Di Timur Indonesia Sunaidin Ode Mulae 102 


\title{
THE INFLUENCE OF STUDENTS' INTERACTION ABILITY IN \\ TEAM WORK TOWARDS STUDENTS' ACHIEVEMENT ABOUT \\ SOCIOLOGY SUBJECT AT THE XI GRADE STUDENTS OF SMA TUNAS \\ BANGSA MAKASSAR.
}

\author{
AKHIRUDDIN \\ ROSNATANG \\ Pengajar pada STKIP Mega Rezky
}

\begin{abstract}
The purpose of research was to know The Influence of students' interaction ability in Team Work towards students' achievement about sociology subject at the XI grade students of SMA Tunas Bangsa Makassar

This research applied kind of ex post facto research with quantitative approach. Data were analyzed by using technique of descriptive data, requirement test technique and linear regression hypothesis test technique. The research was conducted at the XI grade students of SMA Tunas Bangsa Makassar consisting of 30 students as sample in this research. The result of data about students' interaction ability in team work was obtained by giving questionnaire and result of data about students' achievement was obtained by giving evaluation test or formative test.

The result of research was obtained by the average of students' interaction ability 69.10 as a high category and the average of evaluation result or formative test was 7.45 as a high category.
\end{abstract}

\section{Keywords: Ability, Students' Interaction, Team Work}

\section{PENDAHULUAN}

Kualitas pendidikan suatu bangsa dapat dilihat dari sejauh mana output (kelulusan) dari pendidikan itu mampu memecahkan masalah yang dihadapinya dalam kehidupan masyarakat, berbangsa dan bernegara. Usaha menciptakan kualitas output pendidikan, tidak terlepas dari bagaimana proses pelaksanaan pendidikan itu dilaksanakannya. Proses belajar mengajar sebagai wujud pelaksanaan pendidikan dikatakan berhasil apabila guru sebagai salah satu sumber pengetahuan mampu memberikan atau menerapkan ilmunya dengan metode yang sesuai, sehingga dapat diterima dengan baik oleh siswa sebagai subyek didik.

Siswa sebagai subyek didik merupakan pusat perhatian dalam menilai keberhasilan proses belajar mengajar. Untuk itulah sebagai upaya dilaksanakan 
guru untuk membangkitkan motivasi dan minat siswa. Siswa harus dibekali kemampuan, pengetahuan dan keterampilan sedemikian rupa, sehingga mampu mampu menghadapi tantangan dan hambatan yang dihadapinya.

Siswa Sekolah Menengah Atas (SMA) pada umumnya sudah memasuki masa remaja. Masa ini disebut pula sebagai masa pubertas atau masa pencarian dan penjajakan identitas diri yang harus dilewati seorang anak dengan berbagai kesulitan dan hambatan dengan adanya ciri-ciri dorongan ingin keluar dan memasuki kelompok sebayanya. Keadaan seperti ini sangat rentang sekali bagi siswa, karena pada masa remaja seorang anak masih mencari jati diri dan masih ingin di perhatikan.

Menurut Hamalik (2003 : 40), bahwa adanya kondisi-kondisi yang mempermudah siswa belajar di antaranya adalah belajar akan lebih efektif, bila siswa tahu bahwa dirinya dikenal, diakui keberadaannya, diterima oleh kelompok dan kehadirannya cukup mempunyai arti bagi lingkungannya. Belajar akan memperoleh hasil maksimal bila setiap guru memahami keadaan siswa dengan berbagai kelebihan dan kekurangan yang dimilikinya sehingga siswa merasa aman dalam proses pembelajaran di kelas.

Secara umum kehidupan sosial sangat berarti pada kehidupan kelompok siswa, hal ini tidak berarti bahwa lingkungan sosial yang lain dapat diabaikan begitu saja, karena kelompok siswa juga selalu berada dalam konteks masyarakat yang luas dan kompleks, oleh karena itu dalam penelitian ini difokuskan pada pengaruh kemampuan berinteraksi siswa dalam belajar kelompok.

Guru bertindak sebagai fasilitator pembimbing dan pengendali ketertiban kerja dengan mempelajari sendiri, mendiskusikan, menemukan, menghayati sendiri konsep-konsep yang terkandung dalam materi yang dibahas, maka diharapkan dapat meningkatkan pemahaman dan menumbuhkan rasa percaya diri sendiri bagi siswa (Djamarah 2005 : 46).

Seorang anak yang memiliki kemantapan pribadi dan jiwa sosial yang matang akan mampu membuat atau menciptakan suatu suasana yang selalu untuk terus berprestasi. Dengan demikian akan tercipta suatu kualitas belajar yang memuaskan.. Terkait dengan mata pelajaran sosiologi, maka penulis 
mengidentifikasikan bahasan ini dengan interaksi siswa dalam belajar kelompok. Adapun gambaran umum interaksi siswa Kelas XI SMA Tunas Bangsa Makassar yakni guru bidang studi sosiologi membagi para siswa menjadi beberapa kelompok belajar yang kemudian kelompok belajar tersebut nantinya akan aktif dan seoptimal mungkin menjalin interaksi yang harmonis dengan sesama anggota, namun akan menciptakan manajemen konflik juga terhadap kelompok belajar lainnya manakala melangsungkan kegiatan diskusi atau debat kelompok. Intensitas keaktifan dan interaksi para siswa pun akan meningkat manakala guru bidang studi sosiologi memberikan sejenis tugas kelompok kepada masing-masing kelompok belajar. Hal ini terlihat jelas manakala kegiatan diskusi kelompok berlangsung, entah itu di kelas ataupun di luar kelas.

Kurangnya interaksi siswa pada saat peroses belajar mengajar baik dengan guru maupun dengan teman kelasnya maka akan mempengaruhi keefektifan dalam peroses belajar mengajar karenanya perlu sekali siswa diarahkan, agar siswa lebih terbiasa berinteraksi baik dengan guru maupun dengan temannya sehingga akan tercipta suasana belajar baik dan menyenangkan pada saat peroses belajar mengajar berlangsung.

Sesuai dengan gambaran yang telah penulis sebutkan di atas, maka ingin penulis ketahui lebih jauh lagi mengenai hal di atas dengan lebih tertuju pada konteks "Pengaruh Kemampuan Berinteraksi Siswa dalam Belajar Kelompok terhadap Prestasi Belajar Sosiologi Siswa Kelas XI SMA Tunas Bangsa Makassar".

\section{Landasan Teori}

\section{Kemampuan Berinteraksi Dalam Belajar Kelompok}

Menurut Djamarah (2005: 11), interaksi yang berlangsung di sekitar kehidupan manusia dapat diubah menjadi" intraksi edukatif "yakni interaksi yang dengan sadar melatakkan tujuan untuk mengubah tingkah laku dan perbuatan seseorang" kemampuan berinteraksi yang dimaksud dalam hal ini adalah kemampuan siswa untuk melakukan kegiatan -kegiatan antar siswa dengan siswa, 
siswa dengan guru dan siswa dengan media. Dalam belajar kelompok siswa menyelesaikan tugas sosiologi yang diberikan oleh guru sosiologi intraksi difokuskan dalam hal, memberikan bantuan (dengan penjelasan atau tanpa penjelasan), meminta bantuan, bernegosiasi atau berdiskusi dan intraksi diluar tugas. Untuk mendalami intraksi tersebut, juga akan diperhatikan aktifitas siswa didalam kelompok selain berinteraksi.

Menurut Dimyati dan Mujiono (2009 : 165) bahwa dalam pembelajaran kelompok komperatif kelas disusun berdasarkan atas kelompok-kelompok kecil atau besar. Setiap kelompok terdiri dari dua atau tiga orang siswa dengan kemampuan berbeda. Siswa belajar kelompok secara kelompok koperatif atau bersama-sama untuk menguasai materi yang disampaikan oleh guru di kelas. Siswa satu dengan siswa lainnya bekerja sama untuk menyalesaikan tugas kelompok, mendorong kelompoknya untuk berpartisipasi, berdiskusi, dan saling menerima dan saling memberi. Siswa perlu diberi peluang untuk belajar bekerjasama dengan orang lain, toleran, empati dan simpati melalui pembelajaran komperatif atau belajar kelompok siswa.

Menurut Lie (1999:28) falsafah yang mendasari model belajar kelompok dalam pendidikan adalah falsafah "homohomini socio". Falsafah ini menekankan manusia sebagai makhluk sosial. Belajar kelompok yang dimaksud dalam penelitian ini adalah belajar yang dilakukan dalam kelompok yang anggotaanggotanya heterogen, ada yang pintar,sedang dan rendah, laki-laki dan perempuan atau latar etnis yang berbeda. Dari kelompok inilah siswa belajar menguasai materi pelajaran melalui kerjasama antar kelompok. Satu aspek penting pembelajaran komperatif ialah pembelajaran yang membantu mengembangkan tingkah laku kelompok komperatif dan hubungan yang lebih baik diantara siswa.

\section{Interaksi Siswa Dalam Belajar Kelompok Sosiologi}

Interaksi siswa dalam belajar kelompok sosiologi sangat dibutuhkan untuk mengembangkan kreatifitas siswa dan motivasi dalam KBM. Metode belajar kelompok, maka akan merangsang siswa untuk mau berfikir dan mengeluarkan 
ide-ide mereka, sehingga memberikan kesempatan bagi siswa untuk mau menyampaikan ide atau pendapat kepada siswa yang lainnya tentang konsep yang ada dalam materi pelajaran sosiologi. Melalui belajar kelompok ini siswa diharapkan terbiasa berkomunikasi tentang hasil pemikiran atau pendapat dan pemahaman tentang materi pelajaran dengan melibatkan secara langsung dalam mencari dan memecahkan sebuah masalah melalui mekanisme kerja kelompok. Metode ini bertujuan memberikan keleluasaan bagi siswa dalam mendalami sebuah materi yang diberikan oleh guru. Selain itu juga metode ini bertujuan untuk memberikan kebebasan berpendapat bagi para siswa dengan temantemannya dalam memecahkan sebuah masalah, karena siswa cenderung lebih leluasa berbicara dengan teman dibandingkan dengan gurunya dan berguna untuk mengubah kondisi belajar yang awalnya monoton menjadi variatif karena menerapkan metode belajar kelompok.

Dalam menerapkan metode ini, maka guru membagi siswa menjadi beberapa kelompok dimana masing-masing kelompok mempunyai anggota sebayak 5 orang. Setelah membagi kelompok maka guru memberikan masalah yang harus diselesaikan. Kemudian setelah itu masing-masing kelompok disuruh maju ke depan untuk mempresentasikan masalah yang sudah diberikan secara bergantian dan bagi kelompok yang belum maju untuk memberikan pertanyaan dan tanggapan kepada kelompok yang sedang presentasi di depan. Adapun aktivitas siswa yang diamati dalam penelitian ini meliputi: (1) Menyelesaikan masalah secara kelompok, (2) Membuat catatan tertulis, (3) Berpikir menyelesaikan masalah, (4) Mengajukan pertanyaan, (5) Mendengarkan penjelasan, (6) Membaca dan memahami materi, (7) Memperhatikan apa yang dikerjakan teman. Berdasarkan aktivitas siswa dapat dikategorikan menjadi tiga kategori yaitu Tinggi, Sedang, dan Rendah.

\section{Prestasi Belajar Sosiologi}

Prestasi belajar adalah sebuah kalimat yang terdiri dari dua kata, yakni prestasi dan belajar. Antara kata prestasi dan belajar mempunyai arti yang 
berbeda. Prestasi adalah basil dari pada suatu kegiatan yang telah dikerjakan, baik secara individual maupun secara kelompok.

Menurut Poerwadarminta dalam Djamarah (1994: 20), "Prestasi adalah hasil yang telah dicapai (dilakukan, dikerjakan dan sebagainya)". Sedangkan menurut Abdul Qohar dalam Djamarah (1994: 20)," Prestasi adalah apa yang telah dapat diciptakan, hasil pekerjaan, hasil yang menyenangkan hati yang diperoleh dengan jalan keuletan kerja".

Sementara, Nasrun Harahap dkk dalam Djamarah (1994: 21), memberikan batasan, bahwa prestasi adalah penilaian pendidikan tentang perkembangan dan kemajuan murid yang berkenaan dengan penguasaan bahan pelajaran yang disajikan kepada mereka serta nilai-nilai yang terdapat dalam kurikulum.

Menurut Mujiono dan Dimiati (2009 : 2), pengertian belajar adalah suatu yang ditandai dengan adanya perubahan pada diri seseorang. Dari pengertian belajar tersebut makna dan tujuan belajar yaitu suatu proses usaha atau interaksi yang dilakukan individu untuk memperoleh sesuatu yang baru dan perubahan keseluruhan tingkah laku sebagai hasil dari pengalaman-pengalaman interaksi.

Menurut Slameto (2003:2), belajar memberikan batasan bahwa belajar merupakan proses usaha yang dilakukan oleh individu untuk memperoleh suatu perubahan tingkah laku yang baru secara keseluruhan sebagai hasil pengalamannya sendiri dalam berinteraksi dengan lingkungannya. Pengertian di atas, memberikan gambaran bahwa belajar harus ditandai dengan adanya usaha dari individu yang belajar dalam suatu lingkungan belajar sehingga membawa perubahan tingkah laku yang berarti bagi individu yang belajar, yang semula tidak tahu menjadi tahu, baik dalam aspek kognitif, apektif maupun psikomotorik.

Dari pengertian di atas dapat disimpulkan bahwa, belajar pada hakikatnya merupakan suatu proses yang ditandai dengan perubahan tingkat kemampuan pada diru individu yang belajar. Perubahan-perubahan tingkah laku sebagai hasil belajar, berlangsung relatif lama dan mempunyai tujuan yang terarah atau teratur berlangsung terus-menerus dan senantiasa bertambah serta tertuju untuk memperoleh sesuatu yang lebih baik dari sebelumnya. Sehingga makin banyak 
usaha belajar yang dilakukan maka makin banyak dan makin baik perubahan yang diperolehnya.

\section{Pengaruh Konseptual Kemampuan Berinteraksi Siswa Dalam Belajar}

\section{Kelompok Terhadap Prestasi Belajar Sosiologi}

Dari kalimat di atas, yaitu antara kemampuan berinteraksi dalam belajar kelompok dengan prestasi belajar sosiologi, kalau dilihat secara harfiah memang sangat berbeda, tapi kalau dihubungkan secara konseptual memang sangat berkaitan erat, karena antara keduanya saling mempengaruhi antara satu dengan yang lainnya.

Untuk lebih jelasnya, karena antara kedua variabel di atas yakni antara kemampuan berinteraksi dalam belajar kelompok dengan prestasi belajar Sosiologi itu adalah dua masalah yang berbeda, namun saling mempengaruhi antara keduanya. Di bawah ini ada beberapa penjelasan yang ditemukan oleh para ahli.

Lie (1993: 3), mengatakan bahwa, paradigma yang lama adalah guru memberikan pengetahuan kepada siswa yang pasif. Banyak guru dan dosen menganggap paradigma lama sebagai satu-satunya alternatif. Mereka mengajar dengan metode ceramah dan mengharapkan siswa duduk, diam, dengan catat dan hafal (3DCH) serta mengadu siswa satu dengan yang lain. Setelah disadari bahwa paradigma belajar di atas kurang baik dan kurang tepat untuk diterapkan pada dunia pendidikan yang semakin maju seperti saat sekarang ini karena tuntutan dalam dunia pendidikan sudah banyak berubah.

\section{Metodologi}

\section{a. Metode}

Dalam penelitian ini yang digunakan adalah ex post facto atau sering disebut dengan ater fact. Artinya, penelitian yang dilakukan setelah suatu kejadian itu terjadi. Disebut juga sebagai restropectivestudy karena penelitian ini merupakan penelitian penelusuran kembali terhadap sesuatu peristiwa atau kejadian dan kemudian menurun kebelakang untuk mengetahuai faktor- yang dapat menimbulkan kejadian tersebut 


\section{Teknik Pengumpulan Data}

Teknik Angket; Arikunto (1998: 140), mengemukakan bahwa "Angket adalah sejumlah pertanyaan tertulis yang digunakan untuk memperoleh informasi dari responden dalam arti laporan tentang pribadinya, atau hal-hal yang ia ketahui". Berdasarkan teori diatas, angket juga disebarkan atau diberikan kepada responden berupa daftar pertanyaan dan pernyataan dalam bentuk pilihan ganda yang sebelumnya telah disediakan jawaban, sehingga responden akan langsung memilih, memberikan tanda rumput $(\sqrt{ })$ atau memberikan tanda silang $(X)$ pada kolom yang telah disediakan dalam lembaran angket tersebut.

Sebelum responden mengisi angket, peneliti mengumpulkannnya dalam ruangan agar lebih fokus dan teliti dalam

\begin{tabular}{|c|l|c|c|}
\hline No & Skor Angket & $\begin{array}{c}\text { Interval } \\
\text { Skor }\end{array}$ & Kategori \\
\hline 1 & $\begin{array}{l}\mathrm{Mi}+\text { Sdi Sampai } \\
\mathrm{Mi}+3 \mathrm{Sdi}\end{array}$ & $40-60$ & Tinggi \\
\hline 2 & $\begin{array}{l}\mathrm{Mi}+\text { Sdi Sampai } \\
\mathrm{Mi}+<\mathrm{Mi}+\mathrm{Sdi}\end{array}$ & $20-<40$ & Sedang \\
\hline 3 & $\begin{array}{l}\mathrm{Mi}+\text { Sdi Sampai } \\
\mathrm{Mi}-\mathrm{Sdi}\end{array}$ & $0-<20$ & Rendah \\
\hline
\end{tabular}
pengisian angket tersebut. Sedangkan durasi yang diberikan adalah 60 menit. Penggunaan metode angket dalam penelitian im adalah bertujuan untuk mengetahui bagaimana kemampuan berinteraksi siswa dalam belajar kelompok terhadap prestasi belajar sosiologi. Adapun pedoman penskoran angket di bawah ini.

\section{Pedoman Penskoran Angket}

Teknik Tes; Menurut Arikunto(1998: 139), “ Post Test adalah sederetan pertanyaan atau latihan dan alat lain yang digunakan untuk mengukur keterampilan pengetahuan, intelegensi, kemampuan atau bakat yang dimiliki oleh individu atau kelompok". Jadi, Tes dilakukan pada akhir pembahasan yaitu; pokok bahasan sosiologi sebagai ilmu yang mengkaji hubungan masyarakat dan lingkungan yang menggunakan metode belajar kelompok, guna melakukan tes akhir adalah untuk mengetahui seberapa besar peningkatan prestasi belajar siswa setelah melakukan belajar kelompok dan tes diberikan dalam bentuk soal esay. Hasil tes ini digunakan untuk memperoleh data mengenai prestasi belajar 
sosiologi siswa kelas XI SMA Tunas Bangsa Makassar setelah menggunakan metode belajar kelompok. Adapun pedoman penskoran prestasi belajar.

\begin{tabular}{|c|c|l|}
\hline No & Nilai & Kategori \\
\hline 1 & $0-59$ & Rendah \\
2 & $60-79$ & Sedang \\
3 & $80-100$ & Tinggi \\
\hline
\end{tabular}

Teknik Dokumentasi; Menurut Rianto(1997:103), "Dokumentasi adalah segala keterangan yang berupa data-data laporan tertulis dari suatu peristiwa itu yang ditujukan untuk menyimpan keterangan tentang peristiwa itu. Metode ini digunakan untuk memperoleh data mengenai prestasi belajar sosiologi siswa kelas XI SMA Tunas Bangsa Makassar sebelum menggunakan metode belajar kelompok dengan melihat nilai tes sebelumnya. Hasil tes sebelumnya digunakan untuk membagi kelompok belajar yang heterogen.

\section{Teknik Analisa Data}

Menurut Surya Brata (1983), "Analisa data ada dua jenis yaitu analisa statistik dan analisa non statistik. Analisa statistik adalah analisa data sesuai dengan data yang berbentuk bilangan sedangkan analisa data non statistik sesuai dengan data yang berbentuk non bilangan". Berdasarkan pendapat di atas dan masalah yang diteliti, yaitu mencari pengaruh kemampuan berinteraksi siswa dalam belajar kelompok terhadap prestasi belajar sosiologi siswa kelas XI SMA Tunas Bangsa Makassar

\section{HASIL PENELITIAN}

Berdasarkan pokok permasalahan, maka data-data yang disajikan yaitu : data nilai aspek kemampuan berinteraksi siswa dalam belajar kelompok dan data nilai aspek prestasi belajar sosiologi kelas XI SMA Tunas Bangsa Makassar

\section{a. Kemampuan Beriteraksi Siswa Dalam Belajar kelompok}


Kemampuan berinteraksi yaitu suatu hubungan sosial yang dinamis antara dua atau lebih individu, dimana hubungan tersebut saling mempengaruhi, mengubah atau memperbaiki kelakuan individu yang lain atau sebaliknya.

Interaksi yang dimaksud dalam hal ini, memberi bantuan dengan penjelasan atau tanpa penjelasan, meminta bantuan, bernegosiasi atau diskusi dan interasi di luar tugas. Untuk mendalami interaksi siswa tersebut, juga akan diperhatikan aktivitas siswa didalam kelompok. Dalam pembelajaran kelompok kooparatif kelas disusun berdasarkan atas kelompok kelompok kecil setiap kelompok terdiri dari lima orang siswa dengan kemampuan berbeda. Siswa belajar kelompok, kelompok kooparatif atau bersama-sama untuk menguasai materi yang disampaikan oleh guru dikelas.

Adapun nilai kemampuan berinteraksi siswa dalam belajar kelompok ini didapatkan dari hasil angket yang telah disebarkan pada siswa yang menjadi sampel penelitian. Berdasarkan data yang telah dikumpulkan, maka skor tertinggi 98 dan skor terendah 55 untuk kelas XI yang menjadi sampel dalam penelitian ini . Setelah dilakukan perhitungan diperoleh nilai rata-rata (mean) untuk kelas XI adalah 69,10

Selanjutnya berdasarkan data hasil tes tersebut dicari pula mean ideal (Mi) dan standar deviasi ideal (SDi) seperti yang telah dikemukakan pada bab III. Karena sekor maksimal ideal $(\mathrm{SMi})=60$ dan skor minimal $=0$ maka diperoleh mean ideal $(\mathrm{Mi})=30$ dan standar deviasi ideal $(\mathrm{SDi})=10$

Jadi berdasarkan nilai rata-rata (mean) yang di peroleh dari hasil penyebaran angket kelas XI yang menjadi sampel dalam penelitian ini maka diperoleh nilai rata-rata (mean) yaitu 69,10 maka secara umum kemampuan berinteraksi siswa dalam belajar kelompok digolongkan kedalam kategori tinggi. Untuk lebih jelasnya sekor angket kemampuan berinteraksi siswa dalam belajar kelompok.

\section{b. Prestasi Belajar Sosiologi}

Berdasarkan aspek hasil belajar siswa kelas XI SMA Tunas Bangsa Makassar yang diperoleh dari hasil tes ulangan harian setelah melakukan penelitian dengan menggunakan metode belajar kelompok pada pokok bahasan 
sosiologi sebagai ilmu mengkaji hubungan masyarakat dan lingkungan, maka diperoleh skor tertinggi 9,8 dan skor terendah 4,5 untuk sampel penelitian setelah dilakukan perhitungan diperoleh nilai rata-rata (mean) untuk kelas XI yang menjadi sampel penelitian adalah 7,45

Jadi berdasarkan nilai rata-rata (mean) yang di peroleh dari kelas XI yang menjadi sampel dalam penelitian ini maka diperoleh nilai rata-rata (mean) yaitu 7,45 maka secara umum prestasi belajar sosiologi digolongkan kedalam kategori tinggi.

\section{Uji Persayaratan Analisis Prestasi Belajar}

Sebagaimana diungkapkan pada bab III terdahulu bahwa uji persyaratan analisis dilakukan untuk membuktikan normalitas dan Linieritas data pengaruh kemampuan berinteraksi siswa dalam belajar kelompok terhadap prestasi belajar sosiologi siswa kelas XI SMA Tunas Bangsa Makassar.

\section{Uji normalitas Data}

Berdasarkan hasil pengujian normalitas terakhir dengan menggunakan rumus Chi - Kuadrat $\left(x^{2}\right)$ terhadap masing-masing data di peroleh hasil pengujian sebagai berikut.

Ringkasan uji normalitas

\begin{tabular}{|l|l|l|l|}
\hline No & Kelas & $\begin{array}{c}\text { Harga } \\
\times 2 \text { hitung }\end{array}$ & $\begin{array}{c}\text { Harga } \times^{2} \\
\text { tabel }\end{array}$ \\
\hline 1 & Kelas XI & 10,2 & 12,592 \\
\hline
\end{tabular}

Dari tabel diatas dapat disimpulkan bahwa tes kemampuan akhir tersebar normal karena semua harga $x^{2}$ hitung $<x^{2}$ tabel pada d.b $=(\mathrm{k}-3)$ dengan taraf singnifikasi $5 \%$.

\section{Uji Linieritas}

Uji linieritas yang digunakan adalah uji F. hasil F hitung yang diperoleh untuk keperluan ini dikonsultasikan pada tabel $\mathrm{F}$ pada taraf singnifikasi 5\% dengan derajat kebebasan regresi adalah ( k-2) ( $\mathrm{n}-\mathrm{k}$ ) dimana $\mathrm{N}$ adalah ukuran sampel dan $\mathrm{K}$ adalah banyak kelompok.

Setelah diadakan perhitungan dengan uji linieritas (lihat lampiran 15), berikut ini disajikan ringkasan hasil analisia data pada tabel berikut. 
Ringkasan Uji Linieritas

\begin{tabular}{|l|c|c|l|}
\hline Nama sekolah & \multicolumn{2}{|c|}{ F linieritas } & Ket. \\
\hline $\begin{array}{l}\text { SMA Tunas } \\
\text { Bangsa } \\
\text { Makassar }\end{array}$ & Hitung & Tabel & \\
\cline { 2 - 3 } & 0,644 & 2,13 & Linier \\
\hline
\end{tabular}

Dari tabel diatas dapat disimpulkan bahwa bentuk regresi linier diterima karena $\mathrm{F}$ hitung < dari $\mathrm{F}$ tabel dengan $\mathrm{dk}=(\mathrm{k}-2):(\mathrm{n}-\mathrm{k})$ dengan taraf signifikan $5 \%$.

\section{Uji Hipotesis Regresi Linier}

Untuk melakukan uji hipotesis data yang telah dikumpulkan dianalisis dengan menggunakan teknik uji F. hifotesis yang diajukan pada bab III yaitu hipotesis alternatif (Ha) harus menjadi hipotesis nihil (Ho).

Adapun hipotesis yang sudah diajukan pada bab II ada pengaruh antara kemampuan berinteraksi siswa dalam belajar kelompok terhadap prestasi belajar sosiologi siswa kelas XI SMA Tunas Bangsa Makassar.

Dari hasil perhitungan (lihat lampira 15-16) diperoleh F hitung 0,644 dan F tabel 2,13 Pada taraf singnifikasi 5\% karena $\mathrm{F}$ hitung < F tabel, ini berarti Ho ditolak dan Ha diterima, sehingga hipotesis yang diajukan pada bab II dapat dipertahankan. Dengan demikian ada pengaruh kemampuan berinteraksi siswa dalam belajar kelompok terhadap perestasi belajar sosiologi siswa kelas XI SMA Tunas Bangsa Makassar.

\section{PEMBAHASAN}

Dari hasil penelitian dan hasil perhitungan yang telah dilakukan diatas, menyatakan bahwa : Ada pengaruh kemampuan berinteraksi siswa dalam belajar kelompok terhadap prestasi belajar sosiologi siswa kelas XI SMA Tunas Bangsa Makassar.

Dikatakan memiliki pengaruh karena adanya pengaruh yang positif terhadap prestasi belajar siswa, dengan adanya kemampuan berinteraksi siswa dalam belajar kelompok, yang melibatkan secara langsung siswa untuk berinteraksi, baik dalam kelompok maupun diluar kelompoknya. Disamping prestasi belajar siswa meningkat, siswa juga biasa dengan mandiri menyelesaikan masalah dan mengkomunikasikan apa yang menjadi kesulitanya 
Karena dalam pembelajaran ini siswa diberikan kebebasan untuk mendiskusikan materi sosiologi antara kelompoknya dan dapat mengkomunikasikannya. Siswa terlihat semangat dalam belajar sendiri lebihlebih dalam belajar kelompok. Kemudian guru memberikan bimbingan kepada setiap kelompok untuk dapat mengkomunikasikannya atau tukar pendapat antar kelompok yang satu dengan kelompok yang lainnya.

Interaksi yang dimaksud dalam hal, memberi bantuan (dengan memberi penjelasan atau tampa penjelasan), meminta bantuan , bernegosiasi (diskusi) dan interaksi diluar tugas, untuk mendalami interaksi siswa tersebut, juga akan diperhatikan aktivitas siswa didalam belajar kelompok selain berinteraksi dalam pembelajaran kelompok koopratif kelas disusun berdasarkan atas kelompokkelompok kecil dan setiap kelompok terdiri dari beberapa orang siswa dengan kemampuan berbeda. Siswa belajar kelompok secara koopratif atau bersama-sama untuk menguasai materi yang disampaikan oleh guru di kelas.

Dengan demikian siswa seharusnya tidak hanya mampu untuk meyelesaikan masalah dan alasan secara sosiologis, tetapi juga menjadi percaya diri dan menghargai sosiologi, mengkomunikasikannya secara efektif dan menciptakan hubungan antara sosiologi dengan aspek lain dalam kehidupannya lebih-lebih sosiologi adalah ilmu yang membicarakan tentang kemasyarakatan sehingga cocok apabila diterapkan dalam kehidupan sehari-hari.

Untuk mencapai tujuan ini diperlukan suatu strategi pembelajaran yang dapat bmengkomunikasikan interaksi siswa dengan lingkungan belajar. Seperti menggunakan belajar kelompok yang memberikan kesempatan siswa untuk berinteraksi dengan teman sebaya yang bermanfaat untuk meningkatkan prestasi belajarnya, sehingga dapat memiliki kemampuan untuk menyelesaikan masalah yang dihadapi dengan baik dan diharapkan dapat membantu teman-teman dalam kelompoknya yang kurang mampu. Membantu dalam hal ini bukan berarti memberikan penyelesaian, tetapi memberikan petujuk terhadap penyelesaian masalah yang di selesaikan

Menegaskan bahwa kehidupan siswa dalam kelompok merupakan hal yang sangat penting dalam keseluruhan kehidupan dalam siswa, sehingga rasa 
diterima dan dihargai oleh teman kelompok serta status dan kedudukan diantara teman sebaya sangat penting.

Mendifinisikan interaksi sosial adalah suatu hubungan antara dua individu atau lebih, dimana kelakuan individu yang satu mempengaruhi, mengubah, atau memperbaiki kelakuan individu yang lain atau sebaliknya.

Kemampuan berinteraksi adalah kemampuan untuk mengelola hubungan antara dua individu atau lebih dimana perilaku individu yang satu mempengaruhi, mengubah atau memperbaiki perilaku individu yang lain atau sebaliknya.

Sampai sejauh ini peneliti menggunakan istilah "belajar", namun peneliti belum dapat memberikan batasan-batasan belajar. Memang sebenarnya peneliti sangat sulit memberikan arti "belajar", karena "belajar" menyangkut ilmu jiwa kognitif yang dalam dan luas.

Belajar merupakan kegiatan bagi setiap orang, pengetahuan, keterampilan, kebiasan, kegemaran dan sikap seseorang terbentuk, dimodifikasi dan berkembang disebabkan oleh belajar. Karena itu seseorang dikatakan belajar bila dapat diasumsikan dalam diri orang tersebut terjadi proses kegiatan yang mengakibatkan suatu perubahan pada tingkah laku. Misalnya setelah belajar sosiologi siswa mampu memperaktikakan atau mengamalkan dalam kehidupan sehari-hari. Sehingga apa yang didapatkan dalam belajar dapat bermamfaat bagi dirinya dan bagi masyarakat yang luas.

Dengan demikian, maka segala kegiatan yang sedang maupun yang akan dilaksanakan hendaknya didasarkan pada teori yang ada, walaupun teori itu tidak mutlak kebenarannya, karena yang dianggap benar sekarang belum tentu benar untuk masa yang akan datang. Namun demikian, teori yang ada, yang kuno atau yang sudah usang, masih mempunyai arti sebagai awal dari fase-fase penemuan sekarang dan yang akan datang.

Jadi selama manusia ingin mencapai sukses dan selama ia masih bertanggung jawab terhadap hasil usahanya misalnya seorang pendidik yang ingin berhasil dalam mengajar maka ia harus memerlukan pandangan-pandangan teoriteori. Dengan demikian teori sangat diperlukan sebagai landasan dalam peraktek, demikian juga dalam penelitian ini. 
Dari beberapa definisi diatas dapat diambil kesimpulan bahwa kemampauan berinteraksi yaitu suatu pengaruh sosial yang dinamis antara dua atau lebih individu, dimana paengaruh tersebut saling mempengaruhi, mengubah atau memperbaiki kelakuan individu yang lain atau sebaliknya. Memberikan gambaran bahwa belajar harus ditandai dengan adanaya usaha dari individu yang belajar dalam suatu lingkungan belajar sehingga membawa perubahan tingkah laku yang berarti bagi individu yang belajar, yang semula tidak tahu menjadi tahu, baik dalam aspek kognitif, apektif maupun psikomotorik.

Dari pengertian diatas dapat disimpulkan bahwa belajar pada hakikatnya merupakan suatu proses yang ditandai dengan perubahan tingkat kemampuan pada diri individu yang belajar. Perubahan- perubahan tingkah laku sebagai hasil baelajar, berlangsung relatif lama dan mempunyai tujuan yang terarah atau teratur berlangsung terus-menerus dan senantiasa bertambah serta tertuju untuk memproleh sesuatu yang lebih baik dari sebelumnya. Sehingga makin banyak usaha belajar yang dilakukan maka makin banyak dan makin baik perubahan yang diperolehnya.

Berdasarkan paparan di atas, dapat dikemukakan bahwa prestasi belajar adalah kemampuan atau hasil usaha yang dilakukan siswa dalam memperoleh suatu perubahan tingkah laku secara keseluruhan yang menghasilkan perubahan dalam pengetahuan dan pemahaman dalammenguasai materi pelajaran. Setelah melakukan kegiatan belajar diwujudkan dalam nilai yang tertuang dalam raport siswa.

Dalam penelitian ini prestasi belajar diperoleh melalui tes yang dilakukan oleh pengajar bidang setudi sosiologi, setelah materi dan konsep diberikan kepada siswa. Untuk mengetahui prestasi belajar yang diperoleh siswa pada mata pelajaran sosiologi pokok bahasan sosiologi sebagai ilmu yang mengkaji hubungan masyarakat dan lingkungan denagan mengunakan suatu tes harian.

Darii hasil penelitian dan perhitungan yang dilakukan menunjukkan ada pengaruh kemampuan berinteraksi siswa dalam belajar kelompok terhadap prestasi belajar soaiologi siswa kelas XI SMA Tunas Bangsa Makassar, dan ini 
menunjukkan peningkatan prestasi siswa yang cukup baik dan sesuai dengan hipotesis yang direncanakan.

\section{PENUTUP}

\section{Kesimpulan}

Berdasakan hasil penelitian yang telah diperoleh peneliti dari kelas XI yang menjadi sampel dalam penelitian ini dan yang telah dianalisis maka dapat disimpulkan ada pengaruh kemampuan berinteraksi siswa dalam belajar kelompok terhadap prestasi belajar sosiologi siswa kelas XI SMA Tunas Bangsa Makassar, terbukti dari hasil uji linieritas diproleh $\mathrm{F}$ hitung $<\mathrm{F}$ tabel yaitu $=0,644<2,13$ maka dapat disimpulkan ini garis regresi linier Ho ditolak dan Ha diterima.

\section{Saran}

Sehubungan dengan hasil penelitian ini, maka beberapa saran untuk dimengerti sebagai berikut :

Guru diharapkan mampu memberikan bimbingan, mengarahkan dan menerangkan sterategi pembelajaran dengan menggunakan metode belajar kelompok kepada anak didiknya dengan cara memberi tugas kelompok berdiskusi dan berkomunikasi yang akan membantu siswa dalam belajar berinteraksi untuk meningkatkan prestasi belajar sosiologi.

Siswa, untuk mencapai prestasi yang baik, tidak hanya tergantung pada tingkat intelektual saja, melainkan juga dipengaruhi oleh kemampuan berinteraksi . karena itu, sangat penting bagi siswa belajar kelompok dalam meningkatkan prestasi belajar sosiologi.

Sangat diharapkan penelitian selanjutnya, peneliti agar dapat memberikan instrumen yang telah lengkap dan menggunakan populasi yang lebih luas dengan mempertimbangkan variabel-variabel dan memperhatikan faktor- faktor lain yang mempengaruhi kemampuan berinteraksi siswa dalam belajar kelompok dengan prestasi belajar sosiologi.

\section{Daftar pustaka}


Ahmadi, Abu., 1991 “Sosiologi Pendidikan”, Jakarta : Rineka Cipta

Arikunto, Suharsimi, Suharjo dan Supardi, 2006, "Penelitian Tindakan Kelas",Jakartam : Bumi Aksara

Abdulsyani. 2007. Sosiologi Skematika, Teori dan Terapan. PT Bumi Aksara: Jakarta

Alwi. 1997. Kamus Besar Berbahasa Indonesia Edisi III. Balai Pustaka: Jakarta

Bagong, Suyanto, J. Dwi Narwoko. 2007. Sosiologi Teks Pengantar dan Terapan. Prenada Media Group: Jakarta

Budiati. 2009. Sosiologi Kontestual untuk SMA \& MA. CV Mediatama: Jakarta

Bahar, Wilis, Ratna. 1981. Teori-Teori Belajar. Erlangga: Jakarta

Dimyati dan Mudjiono, 2009, “Belajar dan Pembelajaran”, Jakarta : PT. Rineka Cipta

Djamarah, 2005, “Guru dan Anak Didik dalam Interaksi Edukatif”, Jakarta : PT. Rineka Cipta

Furchan, 2002, “Metodelogi PenelitianPendidikan”, Bandung Alfabeta

Jalaluddin Rakhmat, 1999, Psikologi Komunikasi. Bandung : PT. Rosdakarya

Gulo. 2002. Strategi Belajar Mengajar. PT Gramedia Widiasarana Indonesia: Jakarta

Hamalik, oemar. 2001. Proses Belajar Mengajar. PT Rineka Cipta: Jakarta

Mulyasa E, 2007. Menjadi Guru Frofesional. Bnadung : PT Remaja Rosda Karya

Nurkancana Wayan, Sumartana, PPN, 1986. Evaluasi Hasil Belajar. Surabaya : Usaha Nasional.

Roestiyah. 2001. Strategi Belajar Mengajar. PT Rineka Cipta: Jakarta

Hamalik, Oemar, 2003, "Pendidikan Guru Berdasarkan PendekatanKompetensi”, Jakarta Bumi Aksara

Lie, Anita., 1990, “Metode Pembelajaran Gotong Royong”Surabaya: CV.Citra Media 
Sardiman. 2001. Interaksi dan Motivasi Belajar Mengajar. PT Rineka Cipta: Jakarta

Sardiman A.M. 1990, Interaksi dan Motivasi Belajar Mengajar Pedoman Bagi Guru dan Calon Guru.Jakarta : PT Gramadia

Soekanto, Soekanto., 1990, “Sosiologi Suatu Pengantar”, Jakarta : Raja Grafindo Persada

Sudjana. 1989. Dasar-Dasar Proses Belajar Mengajar. Sinar Bandung: Bandung

Slameto. 2003. Belajar dan Faktor-Faktor yang Mempengaruhi. PT Rineka Cipta: Jakarta

Sugiyono, 2008, "MetodePenelitian Kuantitatif Kualitatif dan $R d D$ ”, Bandung Alfabeta

Sugiyono, 2007, “Statistika Untuk Penelitian” Bandung Alfabeta

Sunarto dan Hartono A., 1990, “Perkembangan Peserta Didik” ,Jakarta: Rineka Cipta

Suryobroto. B. 2009. Proses Belajar Mengajar di Sekolah; Edisi revisi. Jakarta: PT Rineka Cipta.

Usman H. dan Akbar, 2003, "Metodologi Penelitian Sosial”, Jakarta: Bumi Aksara 


\title{
STRATEGI PENGEMBANGAN WISATA BAHARI KABUPATEN MOROTAI PROVINSI MALUKU UTARA
}

\author{
Betly Taghulihi, \\ Halida Nuria
}

Pengajar pada Fakultas Sastra dan Budaya Universitas Khairun Ternate

Tourism as a service industry, plays a very important role in the national economy either as one source of foreign exchange, job creation, opening a business opportunity, even able to provide a very large multiplier effect for the national economy. there are 10 (ten) priority tourism destinations established by the government one of which is Morotai Island.

Morotai Island is one of the districts located in North Maluku Province and is one of the largest islands in Malut which has abundant natural resources potential in agriculture, forestry, fishery and marine, mining and historical tourism potential especially places of historical relics of the second world war. This potential can be used as a mainstay sector that has good economic value in an effort to improve the welfare of Malut in general and morotai island community in particular. From the geographical aspect of Morotai island has a strategic position because it is on the lips of Asia Pacific trade route with administrative boundary as the north border of pacific ocean, west bordering with sulawesi sea, east bordering sea of halmahera, and south bordering strait morotai.

Based on the above, it is necessary that the policies - policies that must be taken by the government and relevant stakeholders to determine internal and external factors in it so that it can formulate tourism development programs in Morotai Island, especially marine tourism.

It is expected that the potential of marine tourism in the island of Morotai destinations developed in a long-term in order to become the economic support community of Morotai and for the advancement of tourism North Maluku Province.

Keyword : Development strategy,Marine Tourism, Morotai

\section{Pendahuluan}

Pariwisata sebagai industri jasa, memegang peranan yang sangat penting dalam perekonomian nasional baik sebagai salah satu sumber penghasil devisa, pencipta lapangan kerja, pembuka kesempatan berusaha, bahkan mampu memberikan multiplier effect yang sangat luas bagi perekonomian nasional. 
Kunjungan wisatawan mancanegara yang meningkat menjadi 10,4 juta orang dari target 2015 sebesar 10 juta orang memberikan kontribusi terhadap penerimaan devisa sebesar 114 triliun. Jumlah wisatawan nusantara pun telah mencapai 255 juta perjalanan dengan total pengeluaran sebesar 224,68 triliun, jumlah penyerapan tenaga kerja diperkirakan mencapai 11,3 juta orang (Marjuka,2016).

Pulau Morotai adalah salah satu kabupaten yang terletak di Provinsi Maluku Utara (Malut) dan merupakan salah satu pulau terbesar di Malut yang memiliki potensi sumber daya alam yang cukup melimpah, baik di sektor pertanian, kehutanan, perikanan dan kelautan, pertambangan maupun potensi pariwisata sejarah terutama tempat - tempat sejarah peninggalan perang dunia kedua. Potensi ini dapat dijadikan sektor andalan yang memiliki nilai ekonomis baik dalam upaya meningkatkan kesejahteraan Malut pada umumnya maupun masyarakat pulau morotai pada khususnya. Dari aspek geografis pulau Morotai memiliki posisi strategis karena berada di bibir jalur perdagangan Asia Pasifik dengan batas administrasi sebagai berikut sebelah utara berbatasan dengan samudera pasifik, sebelah barat berbatasan dengan laut sulawesi, sebelah timur berbatasan dengan laut halmahera, dan sebelah selatan berbatasan dengan selat morotai. Berbagai persiapan telah dilakukan oleh Pihak Pemerintah maupun stakeholder terkait untuk pembangunan pariwisata menyangkut penyediaan atraksi, amenitas dan aksesibilitas bagi wisatawan di Pulau Morotai (Anonim, 2016).

Melalui pariwisata, pemerintah berharap menggerakan kegiatan ekonomi, memperbesar penerimaan pajak bagi daerah, membuka lapangan kerja bagi masyarakat sekitar kawasan destinasi tentunya dengan tetap melestarikan lingkungan dan budaya masyarakat. Suatu destinasi wisata menjadi menarik antara lain dengan keunikan, kekhasan dan keanehan aktifitas di dalamnya, artinya sulit atau langka didapatkan persamaannya atau belum ada di dalam kawasan atau masyarakat lain. Aspek keunikan ini seringkali terkait dengan faktor sejarah daya tarik itu sendiri, baik dalam arti yang sebenarnya maupun mitologis. Oleh karena itu dalam mengidentifikasi daya tarik wisata , aspek - aspek tersebut perlu diperhatikan karena dapat menjadi daya tarik yang kuat bagi wisatawan. 
Kualitas destinasi atau daya tarik wisata merupakan salah satu unsur penentu dalam menarik wisatawan untuk datang ke suatu lokasi. Pada umumnya, kualitas tersebut terdiri dari unsur - unsur yang saling tergantung, yaitu atraksi, fasilitas, infrastruktur, transportasi dan pelayanan (hospitality), secara khusus adalah kualitas daya tarik wisata itu sendiri, apakah layak kunjung atau tidak. Fakta memperlihatkan bahwa banyak daerah tujuan wisata di dalam negeri, termasuk Provinsi Malut yang belum sepenuhnya mengantisipasi perkembangan tersebut, baik melalui penyiapan pengembangan atraksi yang menarik maupun sarana prasarana pariwisata yang beragam. Di satu sisi keinginan daerah termasuk pemerintah kabupaten menjadikan pariwisata sebagai sektor andalan pembangunan kelihatan sangat besar namun disisi lain upaya - upaya konkrit dan terukur yang dilakukan untuk mencapai tujuan itu relatif masih sangat terbatas. Pengelolaan dan manajemen destinasi wisata belum dilakukan secara optimal, kurangnya atraksi wisata, aksesibilitas, amenitas, masih terbatasnya pengembangan sarana dan prasarana wisata, minimnya transportasi untuk mencapai ke lokasi wisata, keterbatasan profesionalisme sumber daya manusia (pemerintah, Swasta dan Komunitas) di bidang pariwisata, dan juga belum didukung dengan asosiasi industri yang menghimpun pelaku wisata serta koordinasi antar lembaga pariwisata belum berjalan optimal.

Berdasarkan hal tersebut diatas maka perlu adanya kebijakan - kebijakan yang harus diambil oleh pemerintah maupun stakeholder terkait untuk mengetahui faktor internal dan eksternal didalamnya sehingga dapat merumuskan program program pengembangan pariwisata di Pulau Morotai khususnya wisata bahari.

Diharapkan potensi wisata bahari di destinasi Pulau Morotai dikembangkan secara terencana dalam jangka waktu yang panjang agar menjadi penopang perekonomian masyarakat Morotai dan demi kemajuan pariwisata Provinsi Maluku Utara.

Berdasarkan latar belakang masalah diatas maka yang menjadi tujuan penelitian ini antara lain :

1. Mengetahui kekuatan - kekuatan (Strenghs) apa saja dari objek dan daya tarik wisata bahari yang dimiliki oleh kabupaten Morotai 
sehingga potensi tersebut dapat direncanakan dan dikembangkan secara optimal, terarah dan terpadu.

2. Mengetahui kelemahan - kelemahan (weaknesses) yang dimiliki oleh pemerintah daerah kabupaten morotai terkait dengan optimalisasi pengembangan wisata bahari yang ada saat ini?

3. Mengetahui peluang - peluang (Opportunities) apa yang dapat dilakukan oleh pemerintah daerah, masyarakat dan swasta dalam mengoptimalkan pariwisata bahari kabupaten Morotai.

4. Mengetahui apa saja ancaman - ancaman (threats) apa yang ada saat ini dan yang akan dihadapi oleh pemerintah daerah dan masyarakat yang terkait dengan optimalisasi pengembangan wisata bahari.

\section{Metodologi}

Rancangan penelitian ini dibuat berdasarkan permasalahan penelitian dengan cara survey dilapangan sebagai lokasi dilaksanakan penelitin meliputi identifikasi potensi daya tarik wisata (mendata kondisi, permasalahan dan potensi). Metode yang digunakan dalam rancangan penelitian ini adalah observasi menilai potensi dan layak dikembangkan menjadi wisata bahari, wawancara dengan pihak - pihak terkait yang berhubungan dengan pengembangan pariwisata Morotai antara lain pemerintah daerah (Dinas Pariwisata, Bapedda, Dinas Perhubungan, Dinas PU, Dinas/Badan Lingkungan Hidup, Dinas kehutanan), masyarakat setempat serta pihak - pihak lain yang diidentifikasikan kemudian.

\section{a. Lokasi Penelitian}

Penelitian dilakukan di Morotai secara umum dengan mengunjungi beberapa objek wisata bahari, Dinas pariwisata dan Bapedda Kabupaten Pulau Morotai.

\section{b. Sumber Data}

Data yang digunakan dalam penyusunan penelitian Strategi Pengembangan Pariwisata di Destinasi Pulau Morotai Provinsi Malut adalah data sekunder dan data primer. Berikut gambaran kebutuhan data primer dan data 
sekunder. Data primer adalah data yang diperoleh daii hasil wawancara dan pengamatan oleh peneliti.. Pengumpulan data primer dilakukan dengan menggunakan alat bantu pengumpul data seperti instrument dengan teknik wawancara.. Data primer yang dikumpulkan adalah yang berhubungan dengan potensi, kondisi dan permasalahan pariwisata Morotai. Adapun data Sekunder adalah data yang merupakan hasil pengumpulan tulisan dari berbagai referensi lain dalam bentuk publikasi. Data sekunder diperoleh dari studi literatur, searching internet serta dari instansi dan dinas terkait. Dalam pekerjaan ini data sekunder yang akan dikumpulkan berupa:

1. Profil Kabupaten yang didapat dari institusi pemerintah, penelitian terdahulu.

2. Peta - peta

3. Dokumen hasil - hasil penelitian yang relevan

4. Leaflet, brosur dan booklet pariwisata, dll

\section{c. Instrument Penelitian}

Instrument yang dipergunakan dalam pengumpulan data adalah berupa wawancara, alat perekam gambar dan suara serta alat tulis lainnya sedangkan check list digunakan untuk mengidentifikasikan potensi bahari kabupaten Morotai yang dapat dikembangkan sebagai objek wisata.

\section{d. Metode dan Teknik Pengumpulan Data}

Pengumpulan data dalam penelitian ini menggunakan beberapa teknik yaitu : 1). Observasi, merupakan cara pengumpulan data yang utama dalam pelaksanaan pekerjaan ini. Observasi dalam pelaksanaan pekerjaan ini adalah melakukan kunjungan ke wilayah Kabupaten Morotai. Observasi menilai potensi dan layak untuk dikembangkan menjadi destinasi wisata. Untuk mendapatkan data potensi pariwisata yang memadai, peneliti menggunakan ceklist penilaian daya wisata yang berisi informasi umum, daya tarik wisata (alam, budaya,buatan, sejarah), aksesibilitas, kondisi sarana dan prasarana, kondisi/jumlah wisatawan (pasar), investasi, kelembagaan dan SDM. 2). Wawancara, Merupakan proses interaksi dan komunikasi antara pengumpul data dengan responden/masyarakat, sehingga wawancara dapat diartikan sebagai cara mengumpulkan data dengan 
bertanya langsung kepada responden (wisatawan) dan jawaban - jawaban dicatat atau direkam dengan alat perekam. Wawancara merupakan teknik mengumpulkan data dengan mengajukan pertanyaan secara langsung oleh pewawancara. Dalam penyusunan dokumen ini, wawancara dilakukan dengan pihak - pihak terkait yang sehubungan dengan pengembangan pariwisata Morotai, antara lain dari : Pemerintah daerah (Dinas Pendidikan Provinsi dan Kabupaten, Bappeda, Dinas Perhubungan, Dinas PU, Dinas/Badan Lingkungan Hidup, Dinas Kehutanan) masyarakat setempat serta pihak - pihak lain yang diidentifikasikan kemudian. Materi pertanyaan dalam wawancara yang diberikan kepada responden (masyarakat) secara garis besar meliputi tanggapan terhadap pengembangan pariwisata dan keinginan/saran serta harapan pengembangan pariwisata kedepan khususnya dalam mendukung program pemerintah daerah mewujudkan Morotai sebagai destinasi wisata yang sejahtera dan bermartabat. 3). Dokumentasi, adalah pengumpulan data sekunder melalui dokumen - dokumen yang dimiliki sumber data sekunder. Data diperoleh dari berbagai dokumen resmi pemerintah : Dinas Pariwisata Kabupaten Morotai, Bappeda Kabupaten Morotai dan referensi lainnya yang menunjang data primer.

\section{e. Teknik Analisa Data}

Analisis data merupakan suatu cara berpikir yang merujuk pada pengujian sistematis terhadap sesuatu untuk menentukan bagian - bagiannya, hubungan diantara bagian - bagian serta hubungan bagian - bagian itu dengan keseluruhannya (Spradley 1997:117) Miles dan Huberman (1992:15-20) menyatakan bahwa kegiatan analisis terdiri dari beberapa alur kegiatan yaitu komparasi data (membandingkan data yang satu dengan data yang lain), verifikasi, penyajian data dan argumentasi dan interprestasi. Jalin menjalin dalam bentuk yang sejajar membentuk wawasan umum yang disebut dengan analisis.

Teknik analisis dalam penelitian ini adalah analisis deskriptif kualitatif. Deskritif adalah mentrasformasi data mentah ke dalam bentuk data yang mudah dimengerti dan ditafsirkan, termasuk menyusun, memanipulasi dan menyajikan supaya menjadi suatu informasi. Selanjutnya data akan dianalisis secara kualitatif dengan berpedoman pada teori serta konsep yang terkait dengan mengunakan 
analisis SWOT untuk pemecahan masalah strategi pengembangan pariwisata di Kabupaten Morotai.

\section{f. Teknik Penyajian hasil}

Hasil analisis data disajikan secara verbal dengan teknik deskritif interpretative artinya hasil analisis dipaparkan sebagaimana adanya dan pada bagian tertentu diinterprestasikan sesuai dengan teori dan kerangka pikiran yang berlaku umum. Hasil penelitian atau analisis disajikan dalam bentuk laporan ilmiah.

\section{Hasil dan Pembahasan}

\section{A. Analisis Faktor Internal}

Faktor dominan yang berperan dalam pembangunan kepariwisataan Indonesia menurut Muljadi (2010) antara lain sumber daya alam, penduduk dan geografi. Masing - masing dari faktor tersebut diatas terdiri dari beberapa indikator yang akkan dianalisa untuk mengetahui kekuatan dan kelemahan lingkungan internal.

Untuk mengetahui kekuatan dan kelemahan KPM sebagai destinasi wisata bahari maka dilakukan pembobotan dan penilaian terhadap masing - masing indikator. Langkah selanjutnya adalah mengalikan bobot dengan rating sehingga memperoleh nilai total. Nilai total menunjukkan bagaimana KPM bereaksi terhadap faktor - faktor strategis internalnya.

Lingkungan internal terdiri dari faktor - faktor kekuatan (strengths) dan kelemahan - kelemahan (Weaknesess). Adapun faktor - faktor kekuatan KPM adalah sebagai berikut :

a. Potensi daya tarik wisata yang beranekaragam

b. Potensi bahari dengan pemandangan bawah laut yang menarik dan hamparan terumbu karang yang indah

c. Daerah tujuan wisata yang tersebar di setiap wilayah dengan atraksi yang beraneka ragam.

d. Kondisi lingkungan morfologi yang terdiri dari pegunungan dan sebagian besar maritim. 
Faktor - faktor kelemahan (weaknesess) dari KPM adalah sebagai berikut :

a. Kondisi lingkungan yang rawan badai dan gelombang

b. Wilayah daratan dan beberapa kecamatan yang dipisahkan oleh laut

c. Kualitas sumber daya manusia yang belum memahami tentang kepariwisataan baik dari segi kuantitas maupun kualitas.

d. Kurangnya pemahaman masyarakat tentang pentingnya pengembangan pariwisata di destinasi

e. Kurang optimalnya pemanfaatan beragam potensi pariwisata

f. Kurangnya perhatian pemda terhadap insfrastruktur, jalan raya, listrik dan air bersih.

\section{Pembobotan dan Analisis}

Analisis lingkungan internal dimulai dengan melakukan pembobotan dan penilaian terhadap faktor - faktor kekuatan dan kelemahan yang terdapat pada daya tarik wisata di KPM. Pembobotan dan penilaian diisi oleh responden yang berjumlah 12 orang. Jawaban yang diberikan oleh responden berbeda - beda sehingga perlu membuat rata - rata dari keseluruhan jawaban yang diberikan. Pembobotan dan penilaian terhadap faktor - faktor internal tersebut dapat dilihat pada tabel 4.1

Tabel 4.1 Analisis Terhadap Faktor - Faktor Internal dengan Menggunakan Matriks IFAS (Internal Factors Analysis Summary)

\begin{tabular}{|c|l|c|c|c|}
\hline \multirow{2}{*}{ No } & \multicolumn{1}{|c|}{ Faktor - faktor Internal } & Bobot & Rating & Skor \\
\cline { 2 - 5 } & \multicolumn{1}{|c|}{$\mathbf{2}$} & $\mathbf{3}$ & $\mathbf{4}$ \\
\hline 1 & $\begin{array}{l}\text { Potensi bahari dengan pemandangan } \\
\text { bawah laut yang menarik dan } \\
\text { hamparan terumbu karang yang indah }\end{array}$ & 0.183 & 3,833 & 0,701 \\
\hline 2 & $\begin{array}{l}\text { Potensi daya tarik wisata yang } \\
\text { beranekaragam }\end{array}$ & 0,133 & 3.583 & 0,476 \\
\hline 3 & Daerah tujuan wisata yang tersebar di & 0,120 & 3,583 & 0,429 \\
\hline
\end{tabular}




\begin{tabular}{|c|c|c|c|c|}
\hline & $\begin{array}{l}\text { setiap wilayah dengan atraksi yang } \\
\text { beraneka ragam }\end{array}$ & & & \\
\hline 4 & $\begin{array}{l}\text { Kondisi lingkungan morfologi yang } \\
\text { terdiri dari pegunungan dan sebagian } \\
\text { besar maritim }\end{array}$ & 0,112 & 3,333 & 0,373 \\
\hline \multicolumn{5}{|c|}{ KELEMAHAN } \\
\hline 1 & $\begin{array}{l}\text { Kondisi lingkungan yang rawan } \\
\text { badai dan gelombang }\end{array}$ & 0,150 & 3,250 & 0,487 \\
\hline 2 & $\begin{array}{l}\text { Kualitas sumber daya manusia yang } \\
\text { belum memahami tentang } \\
\text { kepariwisataan baik dari segi } \\
\text { kuantitas maupun kualitas }\end{array}$ & 0,108 & 2,250 & 0,243 \\
\hline 3 & $\begin{array}{l}\text { Kurangnya perhatian pemda terhadap } \\
\text { insfrastruktur, jalan raya, listrik dan } \\
\text { air bersih }\end{array}$ & 0,108 & 2,583 & 0,278 \\
\hline 4 & $\begin{array}{l}\text { Wilayah daratan dan beberapa } \\
\text { kecamatan yang dipisahkan oleh laut }\end{array}$ & 0,104 & 2,333 & 0,242 \\
\hline 5 & $\begin{array}{l}\text { Kurang optimalnya pemanfaatan } \\
\text { beragam potensi pariwisata }\end{array}$ & 0,091 & 2,500 & 0,227 \\
\hline 6 & $\begin{array}{l}\text { Kurangnya pemahaman masyarakat } \\
\text { tentang pentingnya pengembangan } \\
\text { pariwisata di destinasi }\end{array}$ & 0,079 & 1,916 & 0,151 \\
\hline \multicolumn{4}{|c|}{ TOTAL } & 3.607 \\
\hline
\end{tabular}

Sumber : Peneliti, 2016

\section{Pembobotan dan Penilaian Faktor Internal Kekuatan (Strenghts).}

Berdasarkan hasil pada tabel 4.1 diperoleh bahwa faktor kekuatan terpenting pertama adalah potensi bahari dengan pemandangan bawah laut yang menarik dan hamparan terumbu karang yang indah dengan bobot 0,183 dimana terdapat 28 titik point penyelaman yang akan di kembangkan untuk menjadi destinasi terbaik di KPM dan menjadi ikon utama dari KPM. Potensi bahari juga didukung oleh potensi daya tarik wisata yang beranekaragam dengan bobot 0,133 . 
Potensi daya tarik yang dimiliki oleh KPM bukan hanya bahari juga di dukung oleh potensi wisata lainnya seperti wisata budaya dan sejarah. Karena potensi bahari cukup tinggi di KPM maka hampir tersebar di setiap wilayah dengan bobot 0,120 dan mempunyai atraksi yang beranekaragam serta kondisi morfologi yang mendukung dengan bobot 0,112 .

Penilaian faktor - faktor internal yang terdiri dari faktor - faktor kekuatan dan kelemahan menghasilkan peringkat (rating) yang berbeda beda. Faktor kekuatan yang memperoleh tingkat pengaruh pertama dengan nilai 3,833 adalah Potensi bahari dengan pemandangan bawah laut yang menarik dan hamparan terumbu karang yang indah. Potensi daya tarik yang beranekaragam menjadi peringkat kedua dengan nilai 3,583. Daerah tujuan wisata yang tersebar di setiap wilayah dengan atraksi yang beraneka ragam dengan nilai 3,583 dan Kondisi lingkungan morfologi yang terdiri dari pegunungan dan sebagian besar maritim memperoleh nilai 3,333.

\section{Pembobotan dan Penilaian Faktor Internal Kelemahan (Weaknesess)}

Pembobotan faktor internal berupa kelemahan memperoleh bobot yang berbeda - beda. Faktor kelemahan terpenting pertama dengan bobot 0,150 dan rating 3,250 adalah Kondisi lingkungan yang rawan badai dan gelombang, Kualitas sumber daya manusia yang belum memahami tentang kepariwisataan baik dari segi kuantitas maupun kualitas mendapat bobot 0,108 dan rating 2,250. Faktor kelemahan ketiga yaitu Kurangnya perhatian pemda terhadap insfrastruktur , jalan raya, listrik dan air bersih dengan bobot 0,108 dan rating 2,583. Wilayah daratan dan beberapa kecamatan yang dipisahkan oleh laut mendapat bobot 0,104 dan rating 2,333, Kurang optimalnya pemanfaatan beragam potensi pariwisata mendapat bobot 0,091 dan rating 2,500 sedangkan Kurangnya pemahaman masyarakat tentang pentingnya pengembangan pariwisata di destinasi mendapat bobot 0,079 dan rating 1,916.

\section{B. Analisis Faktor Eksternal}

Faktor - faktor peluang (opportunities) dari KPM adalah sebagai berikut :

a. Menjadi salah satu destinasi prioritas

b. Peluang pengembangan wisata bahari 
c. Otonomi daerah menjadi peluang stakeholder pariwisata ikut berperan lebih besar lagi dalam pengembangan wisata bahari

d. Adanya akses ke kawasan wisata

e. Adanya investor untuk berinvestasi di KPM

Faktor - faktor ancaman (threats) di KPM untuk mengembangkan wisata bahari adalah sebagai berikut :

a. Pengaruh budaya luar terhadap keaslian budaya masyarakat di KPM

b. Ketersediaan SDM dibidang pariwisata masih terbatas

c. Keamanan dan kebersihan pantai

d. Kondisi politik global dan nasional

e. kecenderungan masyarakat akan menjual lahan kepada investor

Strategi dan Program Pengembangan Wisata Bahari Kabupaten Pulau Morotai

Berdasarkan faktor - faktor internal yang dianalisis dengan matriks IFAS dan faktor - faktor eksternal yang dianalisis dengan matriks EFAS maka total skor yang diperoleh dari hasil analisis lingkungan internal dan lingkungan eksternal KPM akan dimasukan kedalam matriks Internal Eksternal (IE) berupa tabel seperti yang tercantum pada tabel 4.3. dari penggabungan hasil kedua matriks (IFAS dan EFAS) diperoleh strategi yang bersifat umum, kemudian dilanjutkan dengan menggunakan matriks SWOT untuk merumuskan strategi alternatifnya.

Matriks SWOT menghasilkan empat sel kemungkinan strategi khusus pengembangan yang sesuai dengan potensi serta kondisi internal dan eksternal yang dimiliki oleh KPM dan dari strategi yang dihasilkan dapat dijabarkan berbagai macam program pengembangan wisata bahari KPM.

Analisis lingkungan eksternal dimulai dengan melakukan pembobotan dan pemeringkatan terhadap faktor - faktor peluang dan ancaman yang terdapat pada destinasi wisata bahari KPM. Pembobotan dan pemeringkatan diisi oleh reponden, diperoleh jawaban yang berbeda - beda sehingga perlu untuk membuat rata - rata dari keseluruhan jawaban yang diberikan. Pembobotan dan pemeringkatan terhadap faktor - faktor eksternal tersebut dapat dilihat pada tabel 4.2. 
Tabel 4.2 Analisis Terhadap Faktor - Faktor Eksternal dengan Menggunakan Matriks EFAS (External Factors Analysis Summary)

\begin{tabular}{|c|c|c|c|c|}
\hline & Faktor - Faktor Eksternal & Bobot & Rating & Skor \\
\hline No & $\mathbf{1}$ & 2 & 3 & 4 \\
\hline \multicolumn{5}{|c|}{ PELUANG } \\
\hline 1 & Menjadi salah satu destinasi prioritas & 0,191 & 3,833 & 0,732 \\
\hline 2 & Peluang pengembangan wisata bahari & 0,150 & 3,666 & 0,549 \\
\hline 3 & $\begin{array}{l}\text { Otonomi daerah menjadi peluang } \\
\text { stakeholder pariwisata ikut berperan } \\
\text { lebih besar lagi dalam pengembangan } \\
\text { wisata bahari }\end{array}$ & 0,112 & 3,333 & 0,373 \\
\hline 4 & Adanya akses ke kawasan wisata & 0,091 & 3,250 & 0,295 \\
\hline 5 & $\begin{array}{l}\text { Adanya investor untuk berinvestasi di } \\
\text { KPM }\end{array}$ & 0,087 & 2,750 & 0,239 \\
\hline \multicolumn{5}{|c|}{ ANCAMAN } \\
\hline 1 & $\begin{array}{l}\text { Pengaruh budaya luar terhadap keaslian } \\
\text { budaya masyarakat di KPM }\end{array}$ & 0,092 & 3,386 & 0,035 \\
\hline 2 & $\begin{array}{l}\text { Ketersediaan SDM dibidang pariwisata } \\
\text { masih terbatas }\end{array}$ & 0,079 & 2,263 & 0,178 \\
\hline 3 & Keamanan dan kebersihan pantai & 0,079 & 2,212 & 0,174 \\
\hline 4 & Kondisi politik global dan nasional & 0,067 & 2,137 & 0,134 \\
\hline 5 & $\begin{array}{l}\text { Kecenderungan masyarakat akan } \\
\text { menjual lahan kepada investor }\end{array}$ & 0,067 & 2,083 & 0,139 \\
\hline \multicolumn{4}{|c|}{ TOTAL } & 2,848 \\
\hline
\end{tabular}

Sumber : Data diolah Peneliti, 2016

\section{Penilaian Bobot dan Rating Faktor Eksternal (Peluang)}

Dari tabel 4.2 diperoleh bahwa faktor - faktor peluang dan faktor - faktor tantangan memperoleh bobot yang berbeda - beda. Faktor peluang terpenting dengan bobot dan rating tertinggi adalah 0,732 yaitu menjadi salah satu destinasi prioritas. Seperti kita ketahui bersama bahwa Presiden Jokowi telah menetapkan 
10 Bali Baru sebagai destinasi prioritas dan Morotai termasuk salah satu destinasi prioritas tersebut, tentunya peluang pengembangan Wisata bahari dan pariwisata lainnya akan lebih ditingkatkan oleh pemerintah pusat sebagai bentuk dukungan kepada KPM dengan bobot dan rating 0,549.

Dengan adanya Undang - Undang Nomor 32 Tahun 2004 Tentang Pemerintahan Daerah diharapkan akan memberikan dampak positif bagi pengembangan pariwisata secara khusus wisata bahari. Disadari bahwa setiap potensi kepariwisataan berada di daerah, potensi kepariwisataan ini menjadi daya tarik wisata andalan yang mampu berkembang dan bertahan terus, terpelihara dengan baik tentu sangat ditentukan oleh berbagai kebijakan yang diambil oleh pemerintah terutama pemerintah daerah dan ini menjadi faktor peluang ketiga dengan bobot dan rating 0,373 .

Faktor peluang keempat dengan bobot dan rating 0,295 sama pentingnya dengan faktor peluang ketiga yaitu adanya akses ke kawasan wisata. Dan faktor peluang terakhir adalah adanya investor berivestasi di KPM dengan bobot dan rating 0,239. Dengan adanya program Bali baru di KPM maka tidak menutup kemungkinan investor akan berani berinvestasi di KPM sehingga dapat membuka lapangan kerja untuk masyarakat di KPM.

\section{Penilaian Bobot dan Rating Faktor Eksternal (Ancaman)}

Pemeringkatan terhadap faktor - faktor ancaman menunjukkan peringkat yang berbeda - beda. Faktor - faktor ancaman yang punya pengaruh paling kuat adalah pengaruh budaya luar terhadap keaslian budaya masyarakat di KPM dengan bobot 0,092. Faktor ancaman kedua yaitu ketersediaan SDM dibidang pariwisata masih terbatas dengan bobot 0,079 . Bobot 0,079 adalah keamanan dan kebersihan pantai. Ketika pariwisata berkembangan maka tingkat keamanan akan menjadi sangat ketat dan sangat perlu karena bisa terjadi kriminalitas yang tinggi entah dari wisatawan atau dari masyarakat itu sendiri, sampah pun akan meningkat jika tidak dikoordinasikan dari awal.

Kondisi politik global dan nasional menjadi faktor ancaman keempat dengan bobot 0,067 dan faktor ancaman kelima dengan bobot 0,067 yaitu 
kecenderungan masyarakat menjual lahan kepada investor sehingga membuat masyarakat akan menjadi tamu di tempat sendiri.

\section{Strategi Khusus Pengembangan Pariwisata Kabupaten Pulau Morotai}

Berdasarkan kekuatan dan kelemahan pariwisata KPM maka analisis SWOT akan ditemukan beberapa strategi pengembangan sebagai berikut :

\section{Strategi SO (Strenght Oppurtunity)}

Strategi yang menggunakan seluruh kekuatan KPM untuk memanfaatkan peluang . starategi yang dihasilkan adalah strategi perencanaan produk wisata yang mendukung kebijakan agresif. Program - program yang dihasilkan antara lain :

a. Mengembangkan struktur tata ruang sebagai acuan dalam pengembangan potensi sumber daya laut untuk wisata bahari

b. Menyusun regulasi sebagai basis pengelolaan DTW sekaligus sebagai pembagian fungsi dan peran yang jelas antar stakeholder.

c. Menciptakan Image/Citra pariwisata bahari

d. Meningkatkan aksesibilitas ke Morotai dengan penambahan frekuensi penerbangan ke Oti.

\section{Strategi ST (Strenghts Threat)}

Strategi yang menggunakan kekuatan untuk mengatasi ancaman yang dihadapi. Strategi yang dikembangkan adalah strategi perencanaan pariwisata berkelanjutan dengan program sebagai berikut :

a. Menciptakan produk wisata yang ramah lingkungan

b. Peningkatan kualitas dan profesionalisme masyarakat KPM dalam bidang pariwisata melalui pendidikan formal dan informal.

c. Memperkenalkan kepada masyarakat luas baik wisman maupun wisnu berbagai potensi yang layak dikunjungi.

\section{Strategi WO (Weaknesess Opportunity)}

Strategi yang memanfaatkan peluang dengan meminimalkan kelemahan. Strategi yang dipakai adalah strategi pemasaran dan promosi dengan program program sebagai berikut : 
a. Menginventarisasi dan membuat database sebaran daerah tujuan wisata secara lengkap sebagai informasi awal dalam pengembangan potensi dan promosi pariwisata.

b. Membuat dan mengembangkan pusat informasi wisata di lokasi strategis

c. Menciptakan strategi promosi pariwisata yang terpadu serta perluasan jaringan promosi baik di tingkat mancanegara, nasional maupun regional.

d. Pengembangan infrastruktur dan ekosistem pariwisata.

e. Pemberdayaan Masyarakat.

\section{Strategi WT (Weaknesess Threat)}

Strategi ini adalah strategi yang meminimalkan kelemahan dan menghindari ancaman. Strategi yang dihasilkan adalah sebagai berikut :

a. Meningkatkan peran masyarakat dalam pengelolaan dan pengembangan kepariwisataan khususnya pengelolaan daerah tujuan wisata bahari yang membutuhkan investasi besar dan berdampak langsung kepada masyarakat.

b. Kampanye mengungah kesadaran masyarakat dan wisatawan tentang pentingnya menjaga kelestarian lingkungan.

c. Mendorong pemguatan struktur industri pariwisata, peningkatan daya saing produk pariwisata, penguatan kemitraan pariwisata, penciptaan kredibilitas bisnis dan pengembangan tanggung jawab terhadap lingkungan.

d. membangkitkan partisipasi masyarakat dalam perencanaan, pelaksanaan dan pengawasan kegiatan kepariwisataan melalui penyuluhan, pembinaan dan monitoring.

\section{Simpulan}

Berdasarkan uraian pada bab - bab sebelumnya, dapat disimpulkan bahwa :

1. Hasil analisis matriks IFAS menunjukkan bahwa faktor internal wisata bahari KPM berada pada posisi kuta dengan total skor 3,607 sedangkan 
hasil analisis matriks EFAS menunjukkan bahwa faktor eksternal wisata bahari berada pada posisi sedang dengan total skor 2,848 .

2. Strategi pengembangan KPM dari analisis internal dan eksternal adalah tumbuh dan bina melalui konsentrasi integreasi vertikal yaitu mengintegrasikan aktivitas hulu dan aktivitas hilir. Aktivitas hulu terkait dengan segala sesuatu yang diperlukan untuk memudahkan wisatawan dalam mengunjungi KPM sedangkan aktivitas hilir adalah segala sesuatu yang diperlukan untuk memasarkan produk wisata bahari KPM. Strategi yang dapat diterapkan pada sel I yaitu strategi pengembangan produk wisata. Beberapa alternatif pengembangan yang disusun yaitu strategi perencanaan pariwisata, strategi perencanaan pemasaran/promosi, strategi perencanaan pariwisata berkelanjutan dan strategi pengembangan kelembagaan dan SDM bidang pariwisa

\section{KePustakaan}

Ardika, I gede.2000. Beberapa pokok pikiran tentang pengembangan wisata bahari di Bali, Naskah lengkap seminar nasional. Denpasar. Universitas udayana.

Budiastawa, putu. 2009. Wisata eko spiritual sebagai alternative pengembangan bukit bangle di kabupaten bangli (tesis). Denpasar; universitas udayana.

Utler, R.W.1980. The Concept of Tourism Area Cycle of Evolution: Implications for the Management of Resources. The Canadian Geographer. Vol 24:512 .

Badudu \& Sultan Moh.Zain. 1994. Kamus Umum Bahasa Indonesia. Jakarta: Sinar Pustaka Harapan.

Cooper, c. 1995. Tourism principle and practice. Edinburghh gate harlow Essex CM20 2JE. England. Addison Wesley longman limited..

David, Fred R. 2005. Management : Concepts and Cases. Penterjemah ; Sulistio dan Mahardika.Prentice hall: New Jersey.

Fandeli, chafid. 2002. Perencanaan kepariwisataan alam. Fakultas kehutanan universitas gajah mada, Bulaksumur, Yogyakarta. 
Gunn, Clare A.1998. Tourism Planning, Second Edition, New York: Tailor and Francis.

Kementerian Budpar, 2004. Rancangan Pedoman Pengembangan Pariwisata di Pulau - Pulau Kecil

Kartimin, I Wayan.2011. Strategi Pengembangan Pantai Brawa Sebagai Daya Tarik Wisata Berbasis kerakyatan di Kabupaten Badung. (Tesis). Denpasar:Universitas Udayana.

Miles, mattew B dan Huberman, A. Mitchell. 1992. Analisis Data Kualitatif. Diterjemahkan oleh Tjetjep Jakarta ;Universitas Indonesia

Nirwandar, Sapta, 2003. Pembangunan Sektor Pariwisata di Era Otonomi Daerah (Makalah).

Paturusi, syamsul alam. 2008. Perencanaan kawasan pariwisata. Denpasar : udayana university press.

Poerwadarminta, 2002. Kamus Umum Dalam Bahasa Indonesia. Jakarta : B.Pustaka.

Rangkuti, F.2005. Analisis SWOT tehknik membedah kasus bisnis. Jakarta:Gramedia Pustaka Utama.

Rencana Induk Pengembangan Pariwisata Daerah Morotai, 2014

Wahab Salah, 1996. Manajemen Kepariwisataan.PT. Pradnya Paramita, Bandung.

Yoety, Oka A. 2005. Perencanaan Strategis Pemasaran Daerah Tujuan Pariwisata. Jakarta: PT Pradnya Paramitha.

Yuwana Marjuka, 2016. Stakeholder Meeting DMO Morotai April 2016 di Hotel Batik Ternate.

Website : $\quad$ www.budpar.go.id

$$
\begin{aligned}
& \text { www.pulaumoritaikab.go.id } \\
& \text { www.kemenpar.go.id } \\
& \text { www.kompas.com }
\end{aligned}
$$




\title{
ANALISIS PENGGUNAAN BAHASA INDONESIA RAGAM IKLAN \\ PADA MEDIA ELEKTRONIK
}

\author{
Nirwana \\ Dosen Sastra Indonesia Fakultas Sastra dan Budaya \\ Email : nirwanaunhair@yahoo.co.id
}

\begin{abstract}
The using analysis kinds advertisement in printing and electronic media towards Indonesia language. This studi aims to describe in using kinds advertisements in printing and electronic media towards Indonesia language viewed from side ethic advertisement in printing and electronic media. On generally, an advertisement live on TV or newspaper have same vision and mission namely to give information towards publics also expected to help the publics for doing likes the massage meaning that sundered by an advertisement star.
\end{abstract}

Keyword: advertisement,mission, electronic media

\section{PENDAHULUAN}

Hubungan antar manusia dalam kehidupan sehari-hari baik dalam suasana resmi maupun suasana tidak resmi selalu terkait oleh suatu sarana yang menentukan dapat tidaknya hubungan tersebut berlangsung secara wajar. Sarana yang digunakan tersebut adalah bahasa, dengan bahasa seseorang dapat menentukan pikiran, perasaan, dan kemauannya terhadap orang lain bahkan dalam Abidin (1960:60) menyatakan bahwa perihal bahasa seseorang memperhatikan gambaran tingkat ahklak dan budi pekertinya itulah sebabnya bahasa Indonesia sebagai bahasa nasional yang resmi digunakan oleh Bangsa Indonesia selakuk mengalami perkembangan seiring dengan pengembangan tingkat pemikiran manusia yang menggunakan bahasa tersebut.

Dalam dunia komunikasi bahasa dan jurnalistik memiliki hubungan yang erat dan saling mengisi antar satu dengan yang lainnya tanpa bahasa tujuan komunikasi tidak akan tercapai sebaliknya peranan media dalam hal ini surat 
kabar dan televisi perkembangan dan penyebarluasan bahasa tidak akan berjalan baik.

Peran media cetak maupun elektronik dalam keikutsertaannnya dalam pembinaaan bahasa dapat bersifat positif namun dapt pula bersifat negatif apabila bahasa digunkanan oleh kalangan jurnalis merupakan bahasa yang baik dan terpelihara tentunya pengaruhnya terhadap masyarakat pembacanyan akan baik pula sebaliknya jika bahasa yang digunakan tidak terpelihara baik struktur maupun kosakatanya tentunya pengaruhnya terhadap masyarakat pembacanya akan kurang baik pula.

Seiring dengan Era reformasi dan globalisasi saat ini perkembangan bahasa semakin terasa bahasa bukan hanya berfungsi sebagai identitas suatu bangsa tetapi sebagai alat komunikasi luas melainkan sudah menjadi sarana., untuk meluangkan ide-ide yang sangat erat kaitanya dengan kehidupan manusia. Penuangan ide tersebut akan lebih komunikatif jika jurnalis mengetahui secara pasti pasar pembacanya. Laras bahasa yangn digunakan seorang jurnalis dibidang olaraga tentu berbeda dengan yang membidangi masalah seni dan budaya, hal ini menunjukkan betapa pentingnya penguasaan bahasa dan gaya bahasa dalam tulisan.

Gaya bahasa setiap orang tidak sama karena sifat dan karakter individu yang berbeda-beda.Setiap orang dalam posisinya sebagai individu akan tampil sesuai ciri khasnya dalam mengamati dunianya. Melalui karyanya penulis dikatakan berhasil merefleksikan pengetahuannya dalam bentuk tertulis sehingga menimbulkan keraguan dan penalaran yang mendalam bagi pembacanya. Penulis berupaya menjalin komunikasi yang komunikatif dengan pembacanya melalui permainan gaya kepenulisan salah satu contoh bentuk pemanfaatan gaya bahasa yang unik adalah pada ragam iklan. Pada dasarnya periklanan adalah bentuk komunikasi yang efektif dan efesien. Wujud bahasa yang digunakan dalam penyampaian iklan dibagi atas dua ketegori yaitu: (1) ada iklan yang disampaikan secara lisan seperti melalui radio, dan media elektronik lainnya, (2) ada dalam bentuk tulisan seperti melalui surat kabar, majalah, dan papan reklame. Bahkan saat tidak hanya memperkenalkan atau memasarkan siuatu produk tetapi juga 
memperkenalkan dan memasyarakatkan suatu gagasan. Iklan seperti ini disebut dengan iklan layanan masyarakat seperti iklan pendidikan.

Secara umum iklan berusaha untuk memberikan informasi pada masyarakat pembaca atau masyarakat mengenai suatu hal, keadaan atau barang. Bahasa iklan adalah salah satu laras bahasa yang digunakan dalam periklanan seperti yang terdapat pada surat kabar, majalah, brosur, papan reklame, televisi, radio dan sebagainya. Semua jenis iklan itu bertujuan agar masyarakat pembaca tertarik pada isi pembetitahuan tersebut.

Agar tawaran dapat menarik perhatian pembaca, maka pengungkapan pesan dalam iklan dibuat sedemikian rupa sehingga pembaca tertark untuk membeli barang dan jasa gagasan yang ditawarkan. Lubis (1993:108) mengemukakakan syarat yang harus dipenuhi sebuah iklan adalah : (1) mencolok, (2) menarik hati dan (3) jujur.

Bagaimana peranan bahasa supaya iklan dapat menarik sekaligus bersifat jujur? Menarik dapat disebabkan oleh warna. Bahasa yang menarik untuk disimak, iklan yang pendek dengan penggunaan diksi yang tepat selalu menarik dan memikat. 


\section{Landasan Teori}

\section{Konsep Framing}

Pada dasarnya analisis framing merupakan versi terbaru dari pendekatan analisis wacana khususnya untuk menganalisis teks media. Gagasan mengenai framing pertama kali dilontarkan oleh Beterson pada tahun 1995 (Sudiboyo, 1999:23) i keping-kepingan perilaku

Mulanya frame dimaknai sebagai struktur konseptual atau perangkat kepercayaan yang mengorganisir pandangan politik, kebijakan, dan wacana serta menyediakan kategori-kategori standar untuk mengapresiasikan realitas. Konsep ini kemudian dikembangkan oleh Goffman (1974) menyatakan bahwa yang mengandaikan frame sebagai kepingan-kepingan prilaku. Yang membimbing individu dalam membaca realitas.

Menurut Goffman (Siahan et al, 2001:76-77) secara sosiologis konsep frame analisis memelihara kelangsungan kebiasaan kita mengklasifikasi, mengorganisasi dan menginterprensi secara aktif pengalaman-pengalaman hidup kita untuk dapat memahaminya.

Dilihat dari skemata interprensi itu disebut framingyang memungkinkan individu dapat melokalisasi, merasakan, mengidentifikasi dan memberi label terhadap peristiwa-peristiwa serta informasi, dengan konsep yang sama Gitlin (1980) mendefenisikan frame sebagi seleksi penegasan dan eksklusi yang ketat.

Proses fremi menjadikan media massa sebagai arena dimana informasi tentang masalah tertentu diperebutkan dalam suatu perang simbolik antara berbagai yang sama-sama menginginkan pandangannya didukung pembaca.

\section{Teknik Framing}

Abrar (2000:73) menyebutkan pada umumnya terdapat emapt teknik Mem-Framing berita yang dipakai wartawan, yaitu : (1) ketidaksesuaian sikap dan perilaku, (2) empati membentuk pribadi khayal, (3) daya tarik yang melahirkan ketidakberdayaan, (4) asosiasi menggabungkan kondisi, kebijakan, dan objek yang sedang aktual dengan fokus cerita. 
Jika seorang wartawan ingin mem-framing berita tentang kekerasan terhadap perempuan dengan empati pada korban, tidak berarti ia mesti melupakan kaidah jurnalistik yang paling elementer, seperti nilai berita, layak berita, dan bias berita. Artinya, mereka harus tetap mematuhi dan menjunjung tinggi semua kaidah itu secara saksama. Setelah tahapan itu dilalui, barulah ia melakukan framing terhadap berita.

Sekurang-kurangnya, ada tiga bagian berita yang menjadi objek framning seorang wartawan, yakni: judul berita, fokus berita, dan penutup berita (Abrar, 2007:73) .

- Judul berita di Framming dengan menggunakan teknik empati, yaitu menciptakan" pribadi khayal: dalam diri khayal, sementara khalayak diangkan menempatkan diri mereka seperti korban kekerasan atau keluarga dari korban kekerasan, sehingga mereka bisa merasakan kepedihan yang luar biasa.

- Fokus berita di framing dengan menggunakan teknik asosiasi, yaitu menggabungkan kebijakan aktual denagn fokus berita, Kebijakan dimaksud adalah penghormatan terhadap perempuan.

- Penutup berita di -framing dengan menggunakan teknik packing, yaitu menjadikan khalayak tidak berdaya menolak ajakan yang dikandung berita. Apapun inti ajakan. Khayalak menerima sepenuhnya. Sebab mereka tidak berdaya sama sekali untuk membantah kebenaran yang direkonstruksi berita.

Analisis framing bisa dilakukan dengan bermacam-macam fokus dan tujuan. Tentu saja karena hal ini berkaitan dengan berbagai defenisi dan ruabng lingkup framing sendiri yang cukup komples. Gamson, seperti disinggung, memilah pendekatan framing menjadi dua,yaitu pendekatan kultural dan pendekatan individu satu gagasan perpektif interprestasi interpretatif package. Saat mengkonstruksikan dan memberikan makna suatu isu.

Core framing (gagasan sentral) pada dasarnya berisi elemen-elemen inti untuk memberikan pengertian yang relevan terhadap peristiwa dan 
mengarahkan makna isu yang dibangun condesing Symbol(simbol yang dimanfaatkan)

Condesing symbol adalah hasil pencermatan terhadap interaksi perangkat simbol (framing devices dan reasoning devices) sebagai dasar digunakan perseptif. Symbol dalam wacana terlihat transparan bila dalam dirinya menyusup perangkat bermakna yang mampu berperan sebagai panduan menggantikan sesuatu yang lain. Bagi masyarakat Amerika Serikat (AS), misalnya, mengedarai sebuah Cadillac merupakan pernyataan umum bahwa sang pengemudi telah sukse, atau ia berpikir dirinya telah sukse atau setidak-tidaknya ia ingin agar orang lain beranggapan ia telah sukse. Maka, jadilah merk mobil menjadi simbol status sosial. Dalam tipe merk terkandung nilai-nilai tertentu. Sebuah penelitian menunjukkan, merscedes benz terkait dengan respek pribadi; social dan kenyamanan hidup. Volvo sesuai dengan keamanan keluarga, kenyamanan hidup dengan respek pribadi; sedangkan BMW identik denagn respek; pribadi, kesengan hidup, dan keindahan. (Susanto, 2001:14)

\section{PEMBAHASAAN}

\section{Bahasa Indonesia Ragam Jurnalistik}

Dalam penggunaan bahasa Indonesia dikenal berbagai ragam bahasa dan salah satunya bahasa itu adalah ragam bahasa jurnalistik. Istilaj jurnalistik itu sendiri menurut Memanda (1981:32) mengemukakan semacam kepaduan mengarang yang pokoknya untuk memberikan kabar kepada masyarakat denagn secepatnya agar tersiar seluas-luasnya. Terkait dengan itu Hall (dalam Asnah 1963:32) mengemukakkan bahwa ada dua bentuk jurnalistik yaitu jurnalistik cetak dan jurnalistik saran.

Patmono (1993:56) mengemukakan bahwa yang dimaksud dengan bahasa jurnalistik adalah bahasa komunikasi massa yang dipergunakan dalam majalah, surat kabar, televisi dan radio. Bahasa jurnalistik tidak berbeda dengan bahasa tulis pada umumnya, kecuali beberapa kekhususan yang 
dimilikinya. Di sisi lain, menyimpang, struktur bahasa jurnalistik tidak berbeda dengan tulisan yang baku serta tidak boleh menyimpang dari kaidah bahasa Indonesia yang baik dan benar.

Bagi para jurnalis, bahasa merupakan alat untuk mengungkapkan pikiran, gagasan, dan perasaan. Karena itu, para jurnalis dituntut harus mampu menggunakan nbahasa Indonesia yang baik dan benar, agar informasi yang akan disampaikan menjadi jelas dan dapat dipahami oleh pembaca berbeda-beda itu, maka bahasa Indonesia ragam jurnalis harus memperhatikan ciri bahasa jurnalis, tetapi tidak melupakan penggunaaan bahasa Indonesia yang sesuai dengan kaidah tata bahasa termasuk di dalamnya adalah penggunaan bahasa periklanan.

\section{Gambaran Umum Periklanan}

Periklanan melayani banyak tujuan dan banyak pula pemakaiannya dan mulai dari perorangan yang memasang iklan seperti di media cetak, hingga keperusaaan besar yang memanfaatkan jaringan televisi untuk memperdagangkan merk-mer (dalam Muliadi, 2001:10) mengemukakan bahwa iklan adalah pesan-pesan jualan yang paling persuasif diarahkan kepada calon pembeli atas pruduk barang atau jasa tertentu dengan biaya yang semurah-murahnya.

Berdasarkan pengertian di atas dapat ditegaskan bahwa bahasa yang digunakan dalam dunia periklanan adalah bahasa yang hemat, singkat, dan padat. Persyaratan itu dimaksudkan agar bahasa yang digunakan tidak terlalu berbelit-belit sehingga maksud yang hendak disampaikan dapat diterima oleh pembaca atau pendengar iklan tersebut. Akan tetapi harus disadari pula bahwa adanya persyaratan tertentu seperti singkat dan padat, makaa tidaklah berarti bahwa semua iklan harus wujudnya pendek, sebab ada juga iklan yang menggunakan bahasa yang agak panjang.

\section{a. Jenis-jenis iklan}

Secara garis besar iklan dapat dikelompokkan kedalam tujuh kategori adalah:

1. Iklan konsumen 
Pada dasarnya ada dua macam barang yang umum yang dibeli oleh masyarakat yakni barang konsumen dan barang konsumen dan barang tahan lama keseluruhan macam barang tersebut diiklankan melalui media massa (koran dan televisi) sesuai denagn lapisan masyarakat tertentu yang hendak dibidiknya

2. Iklan Antarbisnis

Pada dasarnya iklan ini berguna untuk mempromosikan barang-barang dan jasa nonkonsumen artinya adalah baik pemasangan maupun sesuai iklan semuannya berasal dari suatu perusahaan

3. Iklan Perdagangan

Iklan ini secara khusus ditujukan kepada kalangan distributor, pedangan yang besar, ageng dan pedangang- pedangan dengan barang-barang yang diiklankan adalah barang-barang yang akan dijual kembali.

\section{Iklan Eceran}

Keunikan iklan eceran karena karakteristiknya berbeda diantara iklan perdagangan dan iklan konsumen yang paling mencolok adalah iklan yang dipromosikan oleh toko serba ada atau pasar swalayang berukuran besar.

\section{Iklan Keunagan}

Secara umum iklan ini meliputi iklan-iklan untuk perbankan, asuransi, jasa tabungan dan investasi.

6. Iklan Lowongan Kerja

Secara garis besar iklan ini terdiri atas dua jenis, yakni yang isi oleh para pencari kerja dan iklan yang berasal dari lembaga perusahaan yang diberi wewenang untuk mencari calon pencari kerja.

7. Iklan gagasan

Iklan jenis ini digolongkan baru, misalnya layangan sosial masyarakat, iklan layangan pemilu dan iklan partai politik. Berdasarkan defenisi di atas dapat dikemukakan bahwa iklan adalah suatu promosi bagi 
perorangan, pengusaha, organisasiatau pun lembaga pemerintahan untuk menyampaikan pesan-pesan yang bersifat menghimbau, memperkenalkan dan sekaligus menguntugkan aspek bisnisnya.

8. Iklan Penulis Naskah Iklan

Kesuksesan sebuah iklan sangat tergantung pada kemahiran penulis iklan dalam menyusun pesan-pesan penjualan melalui bahasa sebagai sarana medianya. Penulis iklan tentu saja harus bekerja sama dengan juru gambar dan ahli jenis huruf guna menghasilkan interprestasi iklan yang artistik. Jelasnya, dengan sebuah iklan yang dirancang oleh anggota tim reatif harus memberikan dukungan yang efektif terhadap penampilan kata-kata ilustrasi dan perilaku jenis huruf. Di samping itu, anggota tim kreatif tersebut tertulis dahulu menyelidiki calon konsumen. Hal ini, dimaksudkan agar dapat diketahui minimal hal-hal berikut: (1) siapa calon pembaca dan pendengar dan pemirsa, (2) apa yang diinginkan dari konsumen sebagai pembaca atau pendengar dan pemirsa, (3) apa pengaruh dan keterangan yang diberikan.

Adapun karakteristik dasar penulisan iklan meliputi : (1) iklan ditulis harus bersifat menjual, meskipun iklan tersebut hanya mengingatkan saja, (2) rahasia keberhasilan iklan adalah pengulangan.Apakah pengulangan tersebut dengan memanfaatkan iklan secara terus menerus ataupun bentuk pengulangan dalam tulisan itu sendiri, (3) pasan iklan harus memanfaatkan secara mekanisme kata-kata, kalimat yang pendek, serta paragraf yang tidak terlalu panjang sehingga memudahkan pembaca untuk memahami maksud iklan tersebut dengan cepat.

Nugroho, (dalam Republik 1999) Menyatakan sebuah iklan bermutu setidaknya mengandung tiga hal : pertama, mampu mengembangkan dan memperluas pasar dan produk yang diklankan. Kedua, mengandung semangat profesionalisme yang tercermin pada keterampilan mengemas iklan. Ketiga, adanya nilai edukasi dalam keterampilan dalam memuat iklan tersebut. 


\section{Kode Etik Periklanan}

a. Asas-asas Umum

- Iklan harus jujur, bertanggungjawab, dan tidak bertentangan dengan hukum yang berlaku.

- Iklan tidak boleh menyinggung perasaan dan merendahkan martabat agama, adat, budaya, suku dan golongan.

- Iklan harus dijiwai oleh asa persaingan sehat

b. Penerapan Umum

- Iklan harus jujur, bertanggungjawab, dan tidak bertentangan dengan hukum yang berlaku.

a. Jujur

Iklan tidak boleh menyesatkan, antar lain dengan memberikan keterangan yang tidak benar, mengetahui dan memberikan janji yang berlebihan.

b. Bertanggungjawab

Iklan tidak boleh menyalahgunakan kepercayaan dan merugikan masyrakat.

c. Tidak bertentangan dengan Hukum

Iklan harus mematuhi Undang-undang dan peraturan pemerintah tyang berlaku.

d. Isi Iklan

Pernyataan dan janji mengenai produk dapat bertanggungjawabkan kebenarannya.

e. Kesaksian dan Konsumen

Harus dilengkapi dengan pernyataan tertulis berdasarkan pengalaman yang sebenarnya. Nama dan alamat pemberi kesaksian harus dinyataka dengan jelas dan benar.

f. Pencantuman Harga 
Jika harga suatu produk dicantumkan dalam iklan dalam iklan, maka harga tersebut harus jelas sehingga konsumen mengetahui barang yang akan diperoleh dengan harga tersebut.

\section{g. Perbandingan Harga}

Jika dilakukan suatu perbandingan dengan harga atas satu produk dengan produk lainya, maka dasar perdandingan tersebut harus sama dan jelas.

h. Pemakaian kata"Cuma-Cuma" atau sejenisnya

Kata "Cuma-Cuma" atau sejenisnya tidak boleh dicantumkan dalam iklan, jika ternyata harus membayar. Apabila biaya pengirim akan dibebankan kepada konsumen, maka harus dicantumkan dengan jelas.

Bahasa adalah alat komunikasi yang sangat vital bagi kehidupan manusia melalui bahasa, sehingga dapat mengungkapkan pikiran ide, dan gagasan terhadap orang lain sehingga dapat terjalin komunikasi yang komunikatif.

Iklan sebagai media penyebarluasaan informasi menggunakan bahasa sebagai sarananya baik secara lisan maupun tertulis. Dalam menuliskan sebuah iklan, penulis iklan tersebut mempertimbangkan beberapa cerita diantaranya: bahasanya harus padat, menarik, komunikatif dan tidak merendahkan produk lainnya. Ide atau gagasan yang hendak disampaikan dikemas dengan rapi dan menarik agar pembaca iklan tersebut dapat tergugah untuk membeli produk yang ditawarkan itu. Untuk itulah maka penulis iklan seharusnya tetap diikuti ketentuan yang berlaku. Dalam hal ini kode seharusnya tetap diikuti ketentuan yang berlaku. Dalam hal ini kode etik periklanan.

\section{SIMPULAN}

Pada dasarnya iklan yang dimuat dimedia cetak dengan iklan yang ditanyankan di televisi memiliki kesamaan dalam beberapa hal kesamaan yang 
paling mendasar adalah misi sebuah iklan yang menginginkan agar pembaca atau pemirsa termotifasi untuk melakukan suatu hal atau membeli sebuah produk seperti yang dilakukan oleh pelibat atau bahasa iklan.

Bahasa iklan yang baik yang bersifat menolong maupun dialog dapat diinterpretasikan berdasarkan tempat pemuatan atau penanyangan, dinterpretasikan berdasarkan waktu pemuatan atau penangan dengan interpretasi tersebut dapat dipertegas bahwa banyak iklan yang memiliki makna secara implisit.

\section{DAFTAR PUSTAKA}

Abidin, Zaenal. 1996. Refleksi Sikap Bahasa. Bandung: Angkasa

Aditama. 1998. Pembinaaan Bahasa Indonesia Melalui Media Massa. Jakarta :

Depdikbud

Alwi, Hasan. 1998. Tata Bahasa Baku Bahasa Indonesia. Jakarta: Depdikbud Anwar, Rosihan. 1984. Bahasa Jurnalistik dan Komposisi. Jakarta: Pradanya

Paramita

Assegraf, Jafar. 1982. Jurnalistik Masa Kini. Jakarta: Galia Indonesia

Badudu, J.S.1984. Cakrawala Bahasa Indonesia. Bandung: CV. Pustaka Prima

Hadi, Parni. 1998.Peranan Pers dalam Permasyarakatan Hasil Hasnah. 1996.

Proposisi Bahasa Indonesia Ragam Jurnalistik. Jakarta : Pradanya

ParamithaPembakuan Bhasa

Keraf, Goris. 1991. Diksi dab Gaya Bahasa. Jakarta: Gramedia

Kridaklaksana, Harimurti. 1997. Kamus Linguistik. Jakarta: Gramedia

Lubis, Muhtar. 1993. Gaya dalam Menulis. Jakarta: Yayasan Obor Indonesia

Mulyadi. 2001. “Analisis Penggunaan Bahasa Indonesia Ragam Iklan”. Tesis.

Universitas Hasanuddin

Poerwadarminta. 1984. Kamus Bhasa Indonesia. Jakarta : Depdikbud

Rahim, Rahman dkk. 1998. Penggunaaan Bahasa Indonesia Ragam Jurnalistik ; Makalah Unhas Makassar

Sudaryanto. 1988. Metode dan Teknik Analisis Wacana. Jakarta: Nusa Indah. 


\title{
Identifikasi potensi budaya Cina \\ Penunjang PariwisataTernate
}

\author{
Rahma Do Subuh, SS,M.Hum \\ Pengajar pada Fakultas Sastra dan Budaya
}

\begin{abstract}
The Chinese exixtence recorded in history since $18^{\text {th }}$ century in Ternate Island, tthis is seen from some artefacs, these is also a kind culture where often heared through parent story. There is interest every rituals who doing till to get positive responds from some people elements. Finally, this culture came back live again for know about the relation with Chinese, cause this can be icon tourism destination in north Moluccas, especially Ternate town.
\end{abstract}

Key words : culture, Chinese, tourism,

\section{PENDAHUL}

Kawasan Maluku utara yang terkenal dengan rempah-rempahnya telah menarik minat dari bangsa lain sejak abad ke -13 . Tercatat dalam sejarah beberapa bangsa di dunia yang berlomba-lomba menduduki daerah ini dengan tujuan menguasai hasil alam yang tidak lain berupa rempah-rempah. tidak terkecuali bangsa Cina yang juga tidak mau ketinggalan. Karenanya pada antara abad 17 dan 18 etnis Cina diperkirakan telah berada di Maluku utara khususnya Ternate. Ini terlihat dari beberapa arsitektur peninggalan yang diperkirakan ada pada abad ke -18 di-Ternate. Selain itu pada abad itu juga telah ada pemukiman etnis Cina yang dikenal dengan nama kampung Cina. Dalam sejarah, disebutkan bahwa bangsa Cina sangat menginginkan tanaman cengkeh, karena konon pada saat itu setiap orang yang ingin bertemu dengan kaisar diharuskan mengunyah cengkeh.

Abad ke-18 di Ternate telah telah dibentuknya pemukiman/kampung Cina dengan jumlah penduduk sebanyak 500 orang dan memiliki dua orang pemimpin kehormatan, seorang "kapten" dan seorang "letnan" pemukiman ini tidak berbeda dengan pemukiman lain di ibu kota tersebut, rumah-rumah di kampung Cina 
seluruhnya dibuat dari batu dengan atap genting, dibangun rapi, bersih serta memiliki sebuah "Kuil Cina" dan rumah panti asuhan

Di antara etnis Cina yang berada di Ternate, terdapat beberapa yang memilih menganut agama Islam yang memang pada saat itu sangat mendominasi wilayah Maluku utara terutama di Pulau Ternate dan Tidore. Bisa jadi dikarenakan adanya hubungan perkawinan dengan orang Ternate. Karenanya hingga saat ini terdapat marga seperti Lim Seng, Qui Liem dan Bo Peng sebagai warga keturunan yang menganut agama Islam. Menyusul kemudian marga seperti Chan dan Chun.

Ritual ke-agama-an (Imlek) telah dilakukan di Ternate pada kisaran abad ke-18. Sumber menunjukkan menyangkut dengan keberadaan orang Cina di Ternate ketika perkampungan mereka telah dibentuk, guna administrasi Kesultanan dan sensus yang dilakukan oleh Kolonial-Belanda demi kepentingan Ekonomi-Politik di Krasidenan Ternate. Sebagian besar penduduk warga di kampung Cina adalah keturunan Cina, namun tidak ada wanita asli Cina di sini. Masyarakatnya menggunakan bahasa Melayu lokal sebagai bahasa ibu. Beberapa bahkan bisa bercakap-cakap dengan bahasa Ternate dan Belanda dengan sangat baik, dan senang bergaul dengan orang pribumi dan Eropa, keakraban mereka dengan kebiasaan (adat) Cina dapat terlihat jelas selama upacara ke-agama-an, perkawinan dan pemakaman. Mereka memegang fungsi resmi dengan mengenakan pakaian yang benar dan rapi, (de Clercq, 1890).

Selain ritual ke-agama-an yang dibuat, kadang dilaksanakan (Festa) pesta perkawinan dan menyambut tahun baru dengan "hela kereta" yang terkenal. Selama pesta berlangsung, dimana kereta kuda kecil yang mengangkut anak-anak, didekorasi (mencerminkan kekayaan orang tua mereka), ditarik mengelilingi kampung tersebut oleh budak dalam sebuah arak-arakan dengan obor, lentera dan musik. Arak-arakan ini biasanya berlangsung selama tiga malam berturut-turut. Setiap orang berpakaian pesta (meriah) dan rumah dihiasi dengan indah. Pada malam keempat ada arak-arakan melewati pemukiman orang Eropa dan pribumi 
(Wallace, 1870), dengan memakai atribut yang dominasi warna merah yang sesuai dengan kegemaran atau tradisi orang Cina.

Perjalanan bangsa Cina ke Maluku dan Maluku utara, ditandai dengan dibangunnya tempat peribadatan yang di sebut klenteng. Disebutkan dalam sejarah, bahwa beberapa abad yang lalu, ada sebuah kapal dagang tiongkok berlayar dengan membawa muatan sebuah papan yang di sebut sen mun yang (dewi penguasa laut). Papan ini di percaya sebagai simbol tempat beribadah bagi bangsa Tingkok. Di tengah perjalanan kapal dihantam badai, para saudagar Tiongkok memohon kepada sang pencipta untuk diselamatkan agar dapat menurunkan papan tersebut dan membangun tempat ibadah.

Akhirnya kapal tersebut terdampar di Tidore. Namun saat itu, tidak ada masyarakat Tionghoa di Tidore sehingga papan tersebut di pindahkan ke Ternate dan didirikanlah tempat ibadah klenteng tian hou king di Ternate. Kini klenteng tersebut masih terpelihara dengan baik serta berdiri kokoh di tengah pusat kota Ternate.

Melihat sejarah dan budaya Cina yang berjalan seiring dengan perkembangan kota Ternate sendiri, maka dalam penelitian ini, diarahkan pada bagaimana pengaruh dan mengidentifikasi berbagai potensi, sejarah,tempat, budaya Cina yang dapat diangkat sebagai potensi wisata daerah minimal dapat menarik wisatawan dari asia dan asia tenggara.

Tujuan Penelitian sebagaimana yang termuat dalam rumusan penelitian adalah, memaparkan kembali pengaruh budaya Cina dalam kehidupan masyarakat Ternate dan mengidentifikasi potensi-potensi yang dapat dikategorikan sebagai potensi wisata seperti wisata budaya dan religi.

\section{TINJAUAN PUSTAKA}

Dalam dokumen sejarah disebutkan bahwa Maluku sudah tercatat dalam tambo dinasti Tang di negeri China (618-906) yang menyebut tentang 'Miliku', yaitu suatu daerah yang dipakai sebagai patokan penentuan arah ke kerajaan Holing (Kalingga) yang ada di sebelah Barat. W.P. Groenveldt memperkirakan 
'Mi-li-ku' ini sebagai Maluku. artinya sekurang-kurangnya Maluku sudah dikenal di negeri China pada abad ke-7.

Seorang sejarawan J.C. Van Leur, menyebutkan bahwa, Sejak abad pertama Masehi, Indonesia sudah turut mengambil bagian dalam perdagangan Asia Purba dengan jalan niaga yang melalui Asia Tenggara dari China di Timur ke Laut Tengah di bagian barat. Pada waktu itu Indonesia terkenal sebagai pengekspor rempah-rempah, bahan obat-obatan, kayu berharga, hasil-hasil hutan, binatang dan burung yang indah. Cengkih adalah satu-satunya tanaman yang hanya terdapat di Maluku waktu itu. Pedagang-pedagang dan pelaut-pelaut China mengetahui Maluku sebagai penghasil cengkeh, akan tetapi mereka merahasiakan jalan pelayarannya."

Dokumen China yang menceritakan panjang lebar mengenai keberadaan Maluku adalah Annaal China dari dinasti Ming (1368-1643), menyebut Maluku berada di laut Tenggara. Sebelum itu, dan sampai dengan 1421, peta navigasi China mengenai keberadaan pulau rempah-rempah disimpan sebagai dokumen rahasia, dan yang dipublikasi adalah peta yang sudah diubah sistem navigasinya. Dalam Annaal China disebutkan bahwa di kawasan asia terdapat suatu pulau yakni

Maluku yang memiliki 'gunung dupa' (incense mountain), dan jika telah 'turun hujan', maka dupa itu berjatuhan menutupi tanah sehingga penduduk tidak mampu menghimpunnya karena banyaknya. Tempat menyimpannya banyak dan kemudian dibawa ke perahu-perahu pedagang untuk dijual.”

Pada tahun 1421, Kaisar Zhu Di, Putra Langit, merupakan tokoh kunci dalam seluruh perkembangan sistem navigasi dan ekspansi armada laut China. Ia kemudian memerintahkan Dinasti Song dan Yuan (bangsa Mongol) untuk membangun perdagangan luar negeri, sehingga kemudian Zhu Di mengontrol perdagangan rempah-rempah dari Arab yang dulu pernah didominasinya. Ia mulai mendorong 250 buah 'kapal harta' besar bertiang sembilan, 3.500 lain, terdiri dari 1.350 kapal patroli dan kapal perang dalam jumlah yang sama, 400 kapal perang besar, 400 kapal barang untuk mengangkut padi, air dan kuda bagi armada lautnya. Tujuan dari ekspansi armada lautnya ialah menciptakan kembali jalur 
perdagangan melintasi Asia Tengah yang pernah dimiliki China di zaman keemasan Dinasti Tang selama lima abad sebelumnya.

Dalam dua dekade, ekspansi armada laut China itu telah berhasil merekrut berbagai potensi kekayaan alam. Bahkan runtuhnya kekaisaran Romawi telah mengakibatkan kemunduran ekonomi dan pertanian di Eropa. Sedangkan China terus berkembang, termasuk dalam bidang pengobatan. Di sini sebenarnya mulai muncul minat Eropa (Spanyol dan Portugis) untuk mengumpulkan bahan pangan, emas, dan rempah-rempah - yang sudah terlebih dahulu diperkenalkan china kepada mereka. pada saat itulah, animo untuk mencari daerah rempah-rempah mulai mempengaruhi orang-orang Eropa.

\section{Proses Perjalanan Masuknya Cina Ke Maluku Utara}

Konflik horizontal yang pernah melanda Ternate pada tahun 1999, membuat banyak warga keturunan Cina yang mengungsi keluar Ternate. Tempat ibadah atau klenteng ditinggalkan orang - orang cina sehingga tempat peribadaan mereka di jadikan tempat tinggal oleh pengungsi padahal di dalam klenteng tersebut terdapat prasasti-prasasti atau peninggalan cina yang di buat dari kayu pada masa itu, tetapi pengungsi pengungsi tersebut tidak tau bahwa itu sangatlah berharga dan bisa menghasilkan nilai jual yang sangat besar/ mahal, malah mereka memanfaatkan dengan menjadikannya kayu bakar. Sehingga pada saat ini prasasti -prasasti cina sudah tidak lagi di temukan terkecuali sebuah kubur yang saat ini berada di bawah kaki kubur pahlawan.

\section{Proses Perdagangan Cina Di Maluku Utara}

Proses dagang China dengan orang-orang Maluku terjadi melalui serangkaian aktifitas negosiasi yang sederhana. Dalam salah satu dokumen dari Ma Huan, seperti dikutip Menzies, diceritakan bagaimana barang-barang dari armada laut dijual dan bentuk kontrak dagang yang digunakan: ...ketika harga telah disepakati, mereka pun mencatat perjanjian itu. Sang ketua dan Chei-Ti bersama dengan tuannya Kasim semuanya bergabung bersama, lalu si 
tengkulak mengatakan: 'Pada bulan dan hari tertentu, kita semua telah bergandengan tangan dan menyepakati perjanjian ini dengan jabat tangan. Meski harga mahal ataupun murah, kita tidak akan pernah membatalkan atau mengubahnya. Tindakan 'jabat tangan' itu dilihat sebagai semacam 'bukti kontrak' atau 'kwitansi' untuk praktek jual-beli. Seperti lazimnya, orang-orang China akan mengambil rempah-rempah berupa cengkeh dari masyarakat Maluku, kemudian mereka meninggalkan berbagai porselin dan barang-barang China lainnya termasuk sutera. Braudel, seperti juga dikutip Menzies, menulis: Bangsa China mengelilingi seluruh negeri. Dengan timbangan (dacing) di tangan, mereka membeli semua rempah yang mereka jumpai. Setelah menimbang sedikit sehingga mereka dapat menentukan kira-kira jumlahnya, mereka menawarkan pembayaran dalam uang gepokan, banyaknya tergantung pada kebutuhan si penjual akan uang. Dengan cara ini mereka dapat menimbun sedemikian banyak sesuai dengan kapasitas kapal-kapal yang datang dari China, dan menjualnya senilai lima puluh ribu caixas (mata uang Portugis), padahal mereka membelinya tidak lebih dari dua belas ribu. Ternyata dengan cara seperti itu, China turut mendominasi perdagangan pada level praksis di masyarakat. Mereka mengontrol penentuan dan tingkat harga, dan karenanya turut mengontrol jumlah distribusi dan pasokan rempah-rempah yang diperdagangkan.

Des Alwi menyebut bahwa hasil penelitian Universitas Brown, Amerika Serikat dengan Yayasan Warisan dan Budaya Banda Naira dan Universitas Pattimura pada 1996-1998, menyebut bahwa "kira-kira 900 sampai 1.000 tahun yang lalu kapal-kapal China sudah berdagang di Banda karena ditemukan pecahan piring-piring zaman Dinasti Ming dan juga pecahan kendi-kendi, tempayan dari tanah liat yang dibuat oleh orang Banda pada zaman Pra Islam abad ke-9. Bendera yang dipakai Kampung Adat Namaswar adalah Naga China, katanya dirampas dari perang di laut dengan bajak laut China. Tetapi sebenarnya bendera naga itu diserahkan oleh pedagang China kepada rakyat Banda. Begitupun kora-kora Ratu dan Namaswar memakai ukiran-ukiran naga".

Dari Pulau Rempah-rempah inilah baru Zhou Man pulang ke China dengan memuat ribuan ton rempah-rempah yang bahkan tersimpan sebagai 
cadangan rempah-rempah dalam gudang, yang kemudian dijual dengan harga 10 kali lebih tinggi dari harga ketika dibeli di pulau rempah-rempah. Sebab itu keberadaan orang-orang China di Maluku sudah ada sebelum masuknya bangsa Eropa. Memang kita masih perlu mencari bukti mengenai apakah dalam perjalanan kembali Ma Huan dan episode setelah itu, sebelum Magellan menemukan jalur rempah-rempah dari peta Rotz, apakah sebagian anggota armada laut China menetap di Maluku atau baru datang setelah Magellan menemukan jalur ini. Sebab beberapa data juga menyebut bahwa pedagang China kemudian membeli tanah dari penguasa-penguasa setempat untuk melakukan berbagai usaha mereka di bidang ekonomi; terutama ketika ditemukan pula adanya produk lain yang laku di pasar eropa seperti teripang, sirip ikan, mutiara, merica, dan lain sebagainya. Kontak orang-orang Buton, Jawa, dan China dengan orang-orang Maluku sudah terjadi sebelum periode perdagangan Eropa. Mereka semua melakukan tindak perdagangan lokal dengan pusat rempah-rempah. Karena itu tidak heran jika cengkeh masuk ke Eropa juga melalui pedagang Arab yang membawanya dari jalur Samudera Pasai. Sebab saat itu Malaka juga menjadi bandar dagang yang penting. Kontak China dengan pedagang-pedagang Arab dan India juga terjadi di bandar Malaka. (Chauvel)

Sisi lain dari data itu ialah komunitas suku-suku tadi di Pulau Saparua juga cukup signifikan. Orang Buton di Saparua pada tahun itu sudah mencapai 1.015 orang, suku Jawa 273 orang, dan China 359 orang. Hal ini perlu diteliti lebih lanjut, sebab terbentuknya komunitas Buton, Jawa, dan China di kawasan ini berdampak pada berbagai aspek dalam kehidupan perekonomian. Orang Buton lebih condong pada usaha perkebunan, sebagai petani penggarap. Dahulu mereka biasa meminta sebidang tanah dari penduduk setempat untuk 'biking kabong'. Mereka bahkan tinggal di 'rumah-rumah kabong' yang sederhana, tetapi yang lambat laun turut mengubah formasi permukiman sosial di tia-tiap negeri. Mulai terbentuk kampung Buton di berbagai tempat, seiring dengan pertambahan penduduk yang adalah anggota keluarga 'orang pertama'. Populasinya berkembang cepat karena perkawinan yang tinggi termasuk 'kawin muda'. 
Sementara orang-orang Jawa dan suku lainnya memiliki sifat bermukim yang tidak sama dengan orang Buton, karena itu hampir tidak ditemui bekas permukiman orang Jawa . Sifat itu pun sama dengan orang China. Namun karena modal yang besar, orang China mengontrol sistem perdagangan lokal dan antarpulau di dalam kawasan-kawasan yang kecil seperti Lease. Sebab itu di hampir setiap negeri, bahkan yang sulit dijangkau oleh transportasi laut sekalipun, sudah dijumpai adanya 'Toko Cina' yang mengontrol perdagangan berbagai hasil alam, hasil kebun, hasil laut, dan juga penjualan barang kelontongan seperti pakaian, nampan, piring, gelas, cangkir,dan lain sebagainya. Secara sosiologis kemudian muncul sebutan seperti Cina Saparua, Cina Dobo, China Banda,China Manado dan lain sebagainya.

\section{Hubungan Etnik Cina dengan Kesultanan Ternate}

Telah disebutkan sebelumnya bahwa hubungan dagang antara bangsa Cina dan Ternate, maka sebelum tahun 1859 sultan Ternate memberi penghargaan kepada mereka bersamaan dengan bangsa Arab dengan memberi kedudukan dalam struktur pemerintahan kesultanan dengan gelar kapita Cina dan Kapita Arab. Dijelaskan bahwa dari ke-41 (atau 43) jumlah Soa yang ada dalam struktur masyarakat tradisional Ternate yang mana klan Melayu seperti Jawa, misalnya, mereka mendapat kedudukan yang boleh dikatakan setara dengan klan lainnya yang asli Ternate.

\section{METODOLOGI PENELITIAN}

Penelitian ini tergolong penelitian deskriptif kualitatif, yakni menggambarkan objek penelitian sebagaimana apa adanya, kemudian menganalisis atau menginterpretasikan berdasarkan apa-apa yang menjadi tujuan dari objek tersebut.

Penentuan Informan 
Dalam metode kualitatif ini, peneliti menentukan dan memilih informan sesuai dengan tujuan penelitian (purposive) yakni informan yang mengetahui dan memahami hal-hal yang berkaitan dengan masalah penelitian. Informan yang dipilih yaitu orang yang mengetahui hal-hal yang akan diteliti dan dari mereka akan diperoleh data yang berhubungan dengan penelitian. Berdasarkan informasi yang diperoleh, peneliti dapat menentukan informan secara purposive, baik informan kunci maupun informan biasa.

Untuk memulai pemilihan informan, peneliti akan secara cermat memilih informan atas pertimbangan-pertimbangan tertentu berdasarkan tujuan penelitian. Menurut Sudikan (2001: 91), penentuan informan kunci didasarkan pada beberapa pertimbangan di antaranya: (1) orang yang bersangkutan memiliki pengalaman pribadi sesuai dengan permasalahan yang diteliti; (2) orang yang bersangkutan bersifat netral, tidak mempunyai kepentingan pribadi; (3) orang yang bersangkutan tokoh masyarakat; dan (4) orang yang bersangkutan memiliki pengetahuan yang luas mengenai permasalahan yang diteliti.

Perbedaaan antara informan kunci dan informan biasa adalah jika informan kunci merupakan orang yang dapat memberi informasi secara detail dan komprehensif serta mempunyai pengetahuan dan pemahaman yang luas tentang masalah yang diteliti, sedangkan informan biasa adalah orang yang dapat memberi informasi secara mendalam mengenai permasalahan yang diteliti namun terbatas pada hal-hal tertentu.

\section{Instrumen Penelitian}

Peneliti merupakan instrumen utama dalam penelitian. Penelitian ini dilakukan dengan wawancara mendalam dan pengamatan langsung di lapangan dengan menggunakan instrumen penelitian, yaitu interview guide (pedoman wawancara) yang disusun secara sistematik untuk lebih memfokuskan pada wawancara yang mendalam. Wawancara ditunjang dengan alat perekam, handycam, dan alat tulis untuk pencatatan hal-hal yang penting. 
Teknik Pengumpulan Data

Teknik pengumpulan data merupakan langkah yang paling strategis dalam penelitian, terkait dengan apa yang harus diperbuat dan bagaimana berbuat dalam rangka mencapai tujuan penelitian. Sehubungan dengan itu, maka teknik yang digunakan dalam mengumpulkan data terdiri atas: 1) observasi, 2) wawancara mendalam, dan 3) studi dokumen.

\section{Observasi}

Menurut Bungin (2008: 115), observasi merupakan kegiatan pengumpulan data yang digunakan untuk menghimpun data penelitian melalui pengamatan dan pengindraan. Kegiatan observasi meliputi pencatatan secara sistematik kejadiankejadian, perilaku, dan obyek-obyek yang diperlukan dalam mendukung penelitian. Peneliti mengumpulkan data atau informasi sebanyak mungkin sehingga peneliti dapat lebih memahami konteks data yang berhubungan dengan penelitian secara holistik atau menyeluruh.

Observasi dilakukan peneliti pada tempat-tempat yang representatif dan dianggap mempunyai nilai historis, nilai budaya dan nilai religi khususnya dari etnik Cina. Teknik pengumpulan data, menurut Bungin, bertumpu pada rumusan masalah dan tujuan penelitian, yang berkaitan dengan kegiatan sosial, kegiatan keagamaan, dan kegiatan sehari-hari masyarakat yang menjadi satuan kajian dalam penelitian.

\section{Wawancara mendalam}

Wawancara mendalam dan terbuka dilakukan pada informan terpilih untuk memperoleh data primer yang diambil di lapangan. Teknik ini bertujuan untuk mengumpulkan data dan informasi lainnya yang berkaitan dengan permasalahan penelitian. Menurut Bogdan dan Taylor (Endraswara, 2003: 214), melalui wawancara mendalam peneliti akan membentuk dua macam pertanyaan, yaitu pertanyaan substantif dan pertanyaan teoretik. Pertanyaan substantif menyangkut 
persoalan yang terkait dengan aktivitas kultural dan pertanyaan teoretik menyangkut fungsi dan makna.

Studi dokumen

Selain observasi dan wawancara, peneliti juga melakukan studi dokumen. Studi dokumen merupakan salah satu teknik pengumpulan data yang berfungsi menunjang pelaksanaan penelitian.

Peneliti mencari berbagai data terutama buku-buku yang cakupan bahasannya menyangkut sejarah dan budaya luar terutama dari Cina, dokumendokumen dan naskah-naskah yang relevan dan berkaitan erat dengan permasalahan yang diteliti. Kebutuhan tambahan sebagai sumber data sekunder sangat penting selain data yang diperoleh dari informan.

Teknik Analisis Data

Analisis data dalam penelitian kualitatif dilakukan terus menerus sepanjang proses penelitian berlangsung, yang dilakukan secara deskriptif-kualitatif dan interpretatif. Analisis data dilakukan mulai dari perumusan masalah, pengumpulan data dan pasca pengumpulan data. Dengan adanya perumusan masalah maka peneliti telah melakukan analisis terhadap permasalahan tersebut dalam berbagai perspektif teori dan metode yang digunakan.

Berdasarkan hal tersebut maka peneliti melakukan proses pengumpulan dan analisis data sepanjang rangkaian kegiatan penelitian dan dituangkan dalam penulisan hasil penelitian. Jadi, analisis data dalam penelitian ini adalah melakukan penyederhanaan data yang terkumpul, yang selanjutnya diolah, ditafsirkan, dan melakukan verifikasi terhadap data yang telah terkumpul tersebut, kemudian disajikan secara sistematik dalam bentuk laporan utuh. 


\section{PEMBAHASAN}

Keberadaan orang Cina di Ternate, bisa dipastikan lebih awal dari orang Jawa, Bugis, Gujarat dan Arab. Bahkan bisa dikatakan bahwa berita tentang keberadaan rempah-rempah di Ternate dari orang-orang sebagaimana disebutkan, berasal dari orang Cina (Djafar, 2005: 107)

Dalam Hikayat Dinasti Tang (618-906), disebutkan eksistensi suatu kawasan yang digunakan untuk menentukan arah daerah Ho- Ling (Kaling) dengan sebutan $\mathrm{Mi}-\mathrm{Li}-\mathrm{Ku}$. Diduga sebutan Mi-Li-Ku ini adalah Maluku. Dalam terminilogi bahasa Cina, $M i-L i-K u$ artinya kepulauan rempah-rempah (Amal, 2007: 4; Tjandrasamita 2001: 19- 20; Djafaar, 2006: 44).

Adapun pengaruh bahasa yang masih digunakan oleh orang-orang Ternate adalah sebutan "Ci”" "kakak perempuan",

“Ko" kakak laki-laki” . Kini kedua sebutan tersebut berkembang menjadi sapaan pada seorang perempuan dewasa dan seorang lakilaki dewasa.

"Ence" sebutan untuk orang tua (lk) berprofesi sebagai penjual

"Encim" sebutan untuk orang tua (pr) berprofesi sebagai penjual

"kong" sebutan untuk kakek

Selain itu, ada sebutan untuk nama-nama kampung yang dipercaya terpengaruh dari kebudayaan (bahasa) Cina yakni Kampung Cina, Kampung Bastiong dan Kampung Santiong.

\section{Pengaruh pada Bangunan (Arsitektur)}

a. Kedaton (istana) Kesultanan Ternate

Dari segi arsitek bangunan, masih terdapat rumah ibadah dan rumah orang Cina yang bergaya Cina sampai saat ini. Rumah ibadah orang Cina di Ternate dikenal dengan nama Tapikong (Rumah Peribadatan Kong $\mathrm{Hu} \mathrm{Chu)}$ 
(Djafaar, 2005: 111). Sementara untuk pengaruh lokalitas, arsitek gaya Cina yang bisa diamati adalah Kedaton Sultan Ternate. Berdasarkan tradisi oral, Kedaton Sultan Ternate dibangun oleh seorang arsitek asal Cina bernama Tiong. Konon nama Tiong kemudian dijadikan sebagai salah satu kampong yang bernama Bastiong. Dalam istilah orang Ternate, seorang arsitek bangunan disebut "Bas", sehingga "Tiong” selalu dipanggil Bastiong. Catatan sejarah menunjukkan, Kedaton Sultan Ternate di bangun pada tahun 1813, pada masa pemerintahan Sultan Mohammad Ali yang berkuasa dari tahun 1807 hingga 1822 (Djuana, 2011:94). Sama halnya dengan mesjid, kedaton juga masuk dalam kategori BCB (Prasasti Peresmian).

Kedaton kesultanan Ternate yang menjadi ikon kebudayaan Maluku utara umumnya dan Ternate khususnya, mempunyai bentuk khas, yakni harimau yang sedang tidur, hal ini dikarenakan ketika dibangun istana kedaton, arsiteknya berasal dari Cina. Bangsa Cina sendiri mempunyai kepercayaan pada hewanhewan tertentu di antaranya harimau, naga dan kucing. Hewan Naga juga menjadi mitos di kota Ternate terutama dalam lingkungan adat kesultanan Ternate yang hingga saat ini masih terdengar.

b. Rumah ibadah

Rumah ibadah etnis Cina atau yang disebut klenteng pertama kali dibangun berada berdekatan dengan perkampungan Arab. Nama klenteng ini dalam bahasa Cina dinamakan sebagai Thian Hou Kiong; Thian berarti istana, hou berarti permai dan kiong artinya langit.

Klenteng Kong $\mathrm{Hu} \mathrm{Cu}$ yang dibangun untuk menghormati dewi laut oleh pelaut dan pedagang Tionghoa sejak permulaan abad ke-17, bernama Thian Ho Kiong (Permaisuri dari Tuhan yang Agung, yang bagi penduduk lokal lebih akrab dengan nama Tapikong, sebagaimana nama jalan di depan Klenteng. Nama ini berasal dari Toa Pe Kong (Toa peartinya besar atau orang tua-tua yg besar, sedangkan Kong adalah istana, juga kebanyakan disebut Dewa Bumi. Di halaman dan ruang dalam Klenteng inilah satu-satunya tempat komunitas Tionghoa merayakan 
imlek, sementara di hari-hari libur biasa halamannya digunakan untuk senam dan latihan Wushu. Klenteng dua lantai ini terdiri atas ruang utama dengan sisi selatan untuk Dewa Bumi, sisi tengah untuk Dewi Laut (Ibu Suri Agung) dan sisi utara untuk panglima perang (Kuan Kong). Sementara ruang belakang untuk Nabi Konghucu dan lantai atas untuk Dewi Kuan Ing. Sebuah rumah di belakang klenteng sudah dibeli untuk digunakan sebagai sekolah minggu, Sekolah tentang agama untuk anakanak. Saat ini, Komunitas Tionghoa sedang berupaya untuk membangun sebuah gapura di dekat jalan raya sebagai penanda masuknya kampung Cina.

Sejak keberadaan etnis Cina di Ternate beberapa tahun lalu, klenteng ini terkenal sebagai pusat ritual Etnis Cina di antaranya barongsai dan karnaval kereta kuda. Namun beberapa tahun belakangan tradisi ini tidak lagi nampak. Rumah ibadah (klenteng) inipun saat ini hanya pada hari hari tertentu dipenuhi warga Tionghoa untuk beribadah. Konflik horizontal beberapa tahun yang lalu juga berdampak pada penghancuran beberapa artefak budaya Cina, di antaranya prasasti-prasasti dan dibakarnya kereta.

c. Perkuburan

Perkuburan Cina yang ada di Ternate, menjadi bukti sejarah masuknya Etnis Cina ke Ternate beberapa abad yang lalu. Setelah hancurnya prasasti-prasasti akibat konflik, perkuburan inilah yang menjadi simbol purbakala bahwa etnis ini telah mendiami pulau Ternate sejak abad ke17SM.

d. Tradisi Barongsai dan Pawai Kereta

Tradisi barongsai dan pawai kereta atau hela kereta dahulunya dilaksanakan setiap tahun tepatnya pada perayaan imlek atau tahun barunya etnik Tionghoa. Dijelaskan bahwa Tradisi ini begitu dikenal oleh masyarakat bukan hanya dari 
warga Cina atau Tionghoa sendiri melainkan juga oleh masyarakat Ternate. Tradisi ini dilaksanakan di pusat kota dan menjadi sajian hiburan yang sangat dinikmati masyarakat. Pertunjukan barongsai hingga puncaknya pawai kereta yang dipenuhi buah-buahan sangat menarik perhatian masyarakat. Warga tumpah ruah di jalan menyaksikan kedua tradisi tersebut. Namun kedua tradisi ini saat ini tidak lagi diadakan. Saat ini perayaan imlek hanya dilaksanakan secara sederhana, hanya terbatas pada ibadah di klenteng dan ziarah ke makam nenek moyang.

\subsection{Pengaruh Kebudayaan lain (Jawa) terhadap Sistem Kebudayaan Masyarakat Ternate}

Di wilayah Ternate, selain bangsa Cina dan Arab sebagai warga pendatang yang telah menjadi bagian dari masyarakat Ternate yakni etnis Jawa. Orang-orang Jawa diduga telah mengadakan kontak dengan orang Ternate, ketika Ternate menjadi bandar utama niaga rempah - rempah jauh sebelum bangsa Portugis, Spanyol, VOC dan Hindia Belanda menanamkan hegemoni di Maluku khususnya Ternate. Salah satu fakta sejarah yang bisa dijadikan acuan adalah ketika Kesultanan Ternate di bawah kendali Sultan Zainal Abidin Syah pada abad ke-16, Ternate pernah terlibat dalam hubungan kerjasama yang dikenal dengan alianasi tiga negara yakni : Ace, Demak dan Ternate (Nachrawy, 2001: 169; Surjo, 2005: 149). Pakta kerjasama tiga negara tersebut sebagai upaya untuk membendung akses perang salib yang mulai meluas ke timur, sekaligus membebaskan buta huruf masyarakat di Indonesia dan Malaisya (Surjo, 2005: 149).

Hubungan kesultanan Ternate dengan suku Jawa dimulai dengan hubungan antara kesultan Ternate dan kerajaan Demak yakni berawal ketika Raja Zainal Abdin memperdalam pengetahuan Islam pada Sunan Giri di Jawa. Dalam hubungan ini, Zainal Abidin kemudian meletakkan dasar-dasar politik Islam dan mengubah sistem politik kerajaan menjadi kesultanan. Zainal Abdin adalah penguasa pertama Ternate yang memakai gelar sultan (Tjandrasasmita, 2001: 19; 
Djafaar, 2006: 45). Adapun pengaruh budaya Jawa terhadap pribadi Sultan Zainal Abdin bisa dilihat dari aspek bahasa (lingustik). Hal ini bisa dilihat dari julukan Sultan Bualawa yang diberikan oleh Sunan Giri kepada Sultan Zainal Abdin Sjah. Dalam terminologi bahasa Jawa, "bualawa" artinya "cengkeh". Hal ini disebabkan karena Sultan Zainal Abdin selalu mempersembahkan buah Cengkeh untuk Sunan Giri (Tjandrasasmita, 2001: 19; Djafaar, 2006: 45). Kondisi ini mungkin tergambar dari pencitraan Ternate sebagai penghasil dan pusat perniagaan rempah-rempah khususnya cengkeh ketika itu. Sebagai konsekuensinya, bualawa sekarang dipakai oleh orang Ternate untuk menyebut cengkeh. Padahal dalam bahasa Ternate, cengkeh disebut gaumedi (Andi Atjo, 2009: 21). Selain pengaruh Jawa dalam bentuk bahasa, ada juga pengaruh lain dalam bentuk arsitek bangunan.

\section{a. Pengaruh Arsitek}

Arsitek bangunan inilah yang menjadi salah sumber daya arkeologi di Ternate. Fakta ini bisa terlihat dari bangunan Mesjid Sultan Ternate yang mirip dengan Mesjid Sultan Demak (Djafar, 2005: 114-115). Bahkan salah satu Imam dari Mesjid Sultan Ternate disebut Imam Jawa, yang bisa disimbolkan sebagai duta orang Jawa di Ternate. Sampai sekarang sebutan Imam Jawa masih digunakan dalam struktur empat Imam Utama di Kesultanan Ternate. Adapun emapt Imam Utama tersebut adalah Imam Jiko, Imam Sangaji, Imam Jawa, dan Imam Moti (Abdullatif Do'a, 2005: 100-101).) Mesjid Sultan Ternate sekarang menjadi benda cagar budaya (BCB) (Prasasti Peresmian)

\section{b. Kesenian}

Pengaruh budaya Jawa yang tak kalah penting terhadap Kesultanan Ternate adalah “musik gamelan" yang biasa dipakai untuk mengantar Sultan Pergi ke Mesjid untuk melaksanakan shalat (Shalat pada malam Qunut, malam Lailatul Qadar, Shalat Idul Fitri dan Idul Adha).

\section{PENUTUP}

\subsection{Kesimpulan}


Dari paparan tersebut di atas, dapat terlihat bahwa budaya Cina pada masa lalu sangat familiar dengan masyarakat Ternate. Bahkan hingga saat ini masyarakat kalangan tua masih mengingat beberapa ritual budaya Cina yang sangat digemari warga saat lalu. Di antara beberapa ritual yang pernah dilakukan, diantaranya pertunjukan barongsai dan kereta kuda. Kedua ritual ini sangat mampu menarik perhatian bukan hanya dari masyarakat lokal namun juga dari berbagai wisatawan dan warga luar Ternate. Mengingat di wilayah lain di Indonesia pertunjukan barongsai sangat dinikmati, maka ada baiknya ritual tersebut dapat dilakukan kembali, demikian juga dengan tradisi hela kereta.

Selain tradisi-tradisi budaya tersebut, terdapat hal lain lagi yang dapat dipertahankan dan dilestarikan yakni bangunan arsitek bercorak budaya Cina antara lain kedaton kesultanan Ternate yang menjadi ikon budaya Ternate serta tempat ibadah (klenteng). Mengingat artefak lainnya seperti prasasti-prasasti dan kereta telah dihancurkan pada saat konflik beberapa tahun lalu.

\subsection{Saran}

Etnis cina yang telah berabad-abad mendiami wilayah Maluku utara dan Ternate khususnya, telah menjadi bagian dari keragaman etnis dan budaya di wilayah ini. Tidak bias dipungkiri juga etnis Cinalah yang mendominasi pergerakan ekonomi di wilayah ini, maka sudah selayaknyalah mereka diberi ruang baik oleh pemerintah daerah, maupun masyarakat umum. Ruang yang diberi dapat saja berupa menghidupkan kembali tradisi-tradisi mereka yang telah hilang.

Sebagai benda yang bersifat monumental atau klasifikasi benda yang tidak bergerak, Mesjid dan Kedaton Sultan Ternate serta alat musik gamelan merupakan warisan budaya yang perlu dilestarikan keberadaannya karena memiliki nilai penting bagi sejarah, ilmu pengetahuan, pendidikan, agama, dan/atau kebudayaan. Adapun pengaruh beberapa kata dalam bahasa Jawa dan Cina terhadap bentuk pengucapan masyarakat di Ternate, memperkuat adanya pengaruh arsitek bangunan Jawa dan Cina di Ternate. 


\section{DAFTAR PUSTAKA}

Amal, M. Adnan. 2007. Kepulauan Rempah-rempah ; Perjalanan Sejarah Maluku Utara 1250-1950. Makassar: Nala Cipta Litera.

Andi Atjo, Rusli. 2009. Orang Ternate dan Kebudayaannya. Jakarta: Cikoro Trirasuandar.

Abdullatif Do'a, Busranto. "Sistem Kemasyarakatan Tradisional Ternate dalam Perspektif Budaya Modern" dalam Mudaffar Sjah, et al., Moloku Kie Raha dalam Perspektif Budaya dan Sejarah Masuknya Islam. Ternate. HPMT Press.

., 2008. "Prosesi "Jou Kolano Uci Sabea" dan Pelaksanaan Sholat Id di Mesjid Kesultanan Ternate. Diakses dari http://ternate.wordpress.com, pada tanggal 20 Februari 2014, pkl. 02.12 WIT.

Djafaar, Irza Arnyta. 2005. "Pengaruh Kebudayaan Cina Terhadap Masyarakat Moloku Kie Raha" dalam Mudaffar Sjah, et. al. Moloku Kie Raha dalam Perspektif Budaya dan Sejarah Masuknya Islam. Ternate: HPMT Press. Djuana, FX. W. Atma. 2011. Genta Nostra Senhora Del Rorasio. Jakarta: Perguruan Tinggi 17 Agustus 1945.

Djubianto, Tony. 2011. Sumber Daya Arkeologis sebagai Salah Satu Alternatif Pengembangan Kepariwisataan. Bandung. Fakultas Ilmu Budaya Unpad.

Hasan, Abdul Hamid. 2001. Aroma Sejarah dan Budaya Ternate. Jakarta. Antara Pustaka Utama.

Kartodirdjo, Sartono. 1992. Pendekatan Ilmu Sosial dalam Metodologi Sejarah. Jakarta: Gramedia Pustaka Utam

Madjid, Bakhtiar.2009. Revitalisasi Nilai-nilai Sastra lisan dalam Budaya Ternate. (Tesis) Program Pascasarjana, Jurusan kajian Budaya Universitas Udayana.

Nachrawy, Herry RD. 2001. "Ternate Membentuk Wawasan Kebangsaan Terpadu" dalam Yusuf Abdulrahman, et. al. Ternate Bandar Jalur Sutera. Ternate: Lintas.

Suryo, Djoko.2005. "Bulan Sabit di Bawah Rembunan Cengkeh" dalam Mudaffar Sjah, et al., Moloku Kie Raha dalam Perspektif Budaya dan Sejarah Masuknya Islam. Ternate. HPMT Press.

Tjandrasasmita, Uka. 2001. "Struktur Masyarakat Kota Pelabuhan Ternate (Abad ke-14 - Abad ke-17)" dalam Yusuf Abdulrahman, et. al. Ternate Bandar 
Jalur Sutera. Ternate: Lintas. Yatim, Badri. 2000. Sejarah Peradaban Islam; Dirasah Islamiyah II. Jakarta: Raja Grafindo Persada.

http://kutikata.blogspot.co.id/2010/05/jejak-dina-di-maluku.html 


\title{
Penelusuran naskah Kuno Ternate dan Tidore \\ (Tinjauan Filologi)
}

\section{RAHMA DJUMATI, S.S., M.A \\ Pengajar pada Fakultas Sastra dan Budaya Universitas khairun}

\begin{abstract}
Identification of Ancient Manuscript in North Maluku: A Philology Perspective.The aim of this research is to protect the ancient manuscripts in North Maluku. This research applied the philology approach.

The result of research shows that there are six ancient manuscript stored in Ternate sultanate and Tidoresultanate. Ternate sultanate and Tidoresultanate save a lot of ancient manuscript with the apprehensive condition physically, or damaged category because there is not care. Ternate sultanate saved four manuscripts, namely (1) Mushaf Al-quran. The age of that reached 421 years and used letter of Arabic;(2) Ancient manuscript of sultan hand writing. The age of this manuscript reached half century. The content is about letter written by the Sultan of Ternate to Sultan of Aceh. This manuscript is written on 1522; (3) Mushafalquran. This manuscript is 800 years ago and contains about verses of AlQuran; (4) Ancient manuscript of Netherland hand writing. The content is a letter and used Arabic letter or writing. While in Tidore sultanate, there are two manuscripts. (1) Al-Quran is 500 years old. The condition of manuscript is damaged. Content of this manuscript is about verses of Al-Quran and Arabic letter; (2) Ancient manuscript of tembaga book. Content of this manuscript is history of sultans journey in time of ZainalAbidin.
\end{abstract}

Keywords: Identification, Ancient Manuscript, Philology

\section{PENDAHULUAN}

Terkadang sering kita mendengar tentang ungkapan, "warisan budaya". Ungkapan ini menggambarkan sesuatu yang mencakup teks klasik atau teks kuno yang secara turun-temurun diwariskan oleh nenek moyang kepada masyarakat saat ini. Tujuannya agar warisan yang ditinggalkan dapat diketahui isinya, sehingga pantas untuk dihormati. Sebagai masyarakat penerima warisan budaya yang ditinggalkan, mereka mempunyai tanggung jawab untuk menjaga, menghormati, sekaligus merawat karena teks klasik yang ditinggalkan banyak terkandung nilai-nilai yang patuh untuk diteladani. Selain itu dalam teks kuno 
terdapat informasi yang berguna bagi para ilmuwan lainnya, seperti khususnya di bidang sejarah, lingustik, antropologi, dan sastra.

Warisan budaya terdiri atas beberapa diantaranya arkeologi, prasasti, naskah kuno dan peninggalan masa silam lainnya. Peninggalan warisan budaya tersebut tidak dapat diabaikan begitu saja karena didalamnya terkandung makna dan pesan yang baik kepada masyarakat sebagai penerima warisan. Untuk itu peninggalan tersebut patut dijaga dan dilestarikan bersama.

- Terdapat beberapa faktor yang menyebabkan naskah kuno perlu diselamatkan. dalam naskah kuno terdapat pesan yang baik, buah pikiran, buah perasaan, dan informasi mengenai berbagai segi kehidupan yang bernilai positif yang pernah ada. Selain itu kondisi naskah kuno saat ini mengalami kerusakan, karena proses penyalinan yang berulang-ulang. Penggunaan bahan berupa kertas dan tinta yang mengalami kerusakan karena faktor usia/waktu maupun faktor kesengajaan dari penyalinan (Baroroh, Dkk, 2: 1994.)

Naskah kuno yang berada di Nusantara menggunakan tulisan dengan aksara non-latin dan bahasa daerah oleh sebab itu, maka untuk mengetahui tentang isi naskah tersebut dibutuhkan ahli bahasa daerah untuk mengetahui isi teks dan pendekatan filologi untuk melihat isi dan kandungan naskah-naskah kunonya. Filologi adalah ilmu yang berhubungan dengan studi teks, yaitu studi yang dilakukan dalam rangka mengungkapkan hasil budaya yang tersimpan didalam. Filologi adalah ilmu yang berbicara tentang seluk beluk naskah kuno.

Munculnya filologi karena beberapa faktor diantaranya (1) munculnya informasi tentang masa lampau di dalam sejumlah karya tulisan; (2) anggapan adanya nilai-nilai yang terkandung dalam peninggalan tulisan masa lampau yang dipandang masih relevan dengan kehidupan masa sekarang; (3) kondisi fisik dan substansi materi informasi akibat rentang waktu yang panjang; (4) faktor sosial budaya yang melatarbelakangi penciptaan karya-karya tulisan masa lampau yang tidak ada lagi atau tidak sama dengan latar sosial budaya pembaca masa kini; (5) keperluan untuk mendapatkan hasil pemahaman yang akurat (Baroroh, 3: 1994.)

Indonesia adalah negara yang kaya akan budaya peninggalan masa lampau, sehingga banyak tulisan tangan yang dijumpai bertebaran hampir di setiap daerah dalam bentuk, jumlah, jenis dan bervariasi yang berbeda-beda. 
Naskah kuno dikenal dengan sebutan naskah nusantara. Oleh sebab itu, maka naskah kuno tersebut perlu dilindungi agar warisan budaya Indonesia dapat diselamatkan. Apalagi saat ini banyak diincar oleh negara-negara asing, dan meskipun sudah ada Undang-Undang Nomor 11 tahun 2010 yang mengatur tentang larangan penjualan benda cagar budaya, termasuk di dalamnya naskahnaskah kuno. Dengan demikian maka kegiatan penelitian naskah adalah sebagai upaya untuk menelusuri naskah kuno nusantara. Kegiatan ini dilakukan untuk mengumpulan naskah kuno, dan sebagai salah satu bentuk rasa empati terhadap naskah-naskah kuno yang hampir punah dan bahkan terancam diambil oleh negara-negara asing.

Maluku Utara adalah salah satu Provinsi bagian Timur wilayah Indonesia yang juga banyak ditemukan naskah kuno. Maluku Utara dikenal dengan sebutan Moluku Kue Raha adalah salah satu wilayah timur yang dikenal dengan penghasil rempah-rempah, pala dan cengke. Sebagai wilayah penghasil rempah inilah yang membuat Maluku Kue Raha dikenal di negara-negara Eropa, Cina, dan Arab sekitar pada abad abad pertengahan (Leirissa: 2001). Kehadiran Negara-negara tersebut mempunyai misi dan tujuannya masing-masing. Sebut saja Arab, pada waktu menginjak kakinya ditanah Maluku, mereka membawa misi yakni menyiarkan agama Islam. Begitupun juga dengan negara Eropa dan Asia. Secara otomatis maka banyak pengaruh budaya yang berpengaruh di masyarakat. Selain itu tinggalan dalam bentuk naskah-naskah kuno juga ditinggalkan oleh negara tersebut. Banyak ditemukan peninggalan berbentuk arkeologi, prasati-prasasti dan naskah tulisan kuno/naskah yang juga ditinggalan. Penelitian ini lebih difokuskan ada penelusuran naskah-naskah kuno yang ada di Maluku Utara dengan menggunakan pendekatan filologi.

Filologi selama ini dikenal sebagai ilmu yang berhubungan dengan karya masa lampau yang berupa tulisan tangan. Studi terhadap karya tulis masa lampau dilakukan karna adanya anggapan bahwa dalam peninggalan tulisan terkandung nilai-nilai yang masih relevan dengan kehidupan masa kini. Gejala demikian terbaca pada munculnya variasi bacaan dalam karya tulis masa lampau. Berbagai penelitian pun dilakukan untuk mengkaji peninggalan-peninggalan naskah kuno. Studi filologi merupakan studi yang sangat signifikan dalam mengkaji warisan 
budaya (naskah kuno) yang tersebar dipelbagai belahan dunia, dan sangat disayangkan jika tidak diteliti dan dikaji. Masalah yang diangkat dalam penelitian ini adalah menelusuri naskah-naskah kuno yang ada di Maluku Utara dengan tinjauan filologi.

\section{TINJAUAN PUSTAKA}

\section{Pengertian Filologi}

Kata filologi berasal dari bahasa Yunani philologia yang berupa gabungan kata dari philos yang berarti 'teman' dan logos yang berrti 'pembicaraan' atau 'ilmu'. Dalam bahasa Yunani philologia berarti 'senag berbicara' yang kemudian berkembang menjadi 'senang belajar', 'senang kepada ilmu', 'senang kepada tulisan-tulisan' dan kemudian 'senang kepada tulisan-tulisan yang bernilai tinggi' seperti 'karya-karya sastra'.

Sebagai istilah, kata filologi mulai dipakai pada abad ke-3 SM oleh sekelompok ahli dari Iskandariyah, yaitu untuk menyebut keahlian yang diperlukan untuk mengkaji peninggalan tulisan yang berasal dari kurun waktu beratus-ratus tahun sebelumnya. Ahli dari Iskandariyah yang pertama kali melontarkan istilah filologi bernama Eratosthenes. Objek penelitian filologi adalah tulisan tangan yang menyimpan berbagai ungkapan pikiran dan perasaan sebagai hasil budaya bangsa masa lampau. Semua bahan tulisan tangan itu disebut naskah (handschrift dengan singkatan hs untuk tunggal, hss untuk jamak; manuscript dengan singkatan $m s$ untuk tunggal, $m s s$ untuk jamak). Filologi selama ini dikenal sebagai ilmu yang berhubungan dengan karya masa lampau yang berupa tulisan. Studi terhadap karya tulis masa lampau dilakukan karna adanya anggapan bahwa dalam peninggalan tulisan terkandung nilai-nilai yang masih relevan dengan kehidupan masa kini.

Karya-karya tulis masa lampau merupakan peninggalan yang mampu menginformasikan buah pikiran, buah perasaan, dan informasi mengenai berbagai segi kehidupan yang pernah ada. Karya-karya dengan kandungan informasi mengenai masa lampau itu tercipta dari latar sosial budaya yang tidak ada lagi atau yang tidak sama dengan latar sosial budaya masyarakat membaca masa kini. 
Dalam pada itu, peninggalan tulisan yang berasal dari kurun waktu beberapa puluh atau ratus tahun yang lalu pada saat ini dalam kondisi yang sudah mengalami kerusakan, atau berwujud sebagai hasil dari suatu proses penyalinan yang telah berjalan dalam kurun waktu yang lama. Disamping itu, sebagai produk masa lampau, bahan yang berupa kertas dan tinta serta bentuk tulisan dalam berjalan waktu, semenjak diciptakan sampai pada saat ini, telah mengalami kerusakan atau perubahan, baik karena faktor waktu maupun karena faktor kesengajaan dari penyalinan. Gejala demikian terbaca pada munculnya variasi bacaan dalam karya tulis masa lampau.

Lahirnya filologi dilatarbelakangi oleh sejumlah faktor berikut 1) munculnya informasi tentang masa lampau di dalam sejumlah karya tulisan; 2) anggapan adanya nilai-nilai yang terkandung dalam peninggalan tulisan masa lampau yang dipandang masi relevan dengan kehidupan masa sekarang; 3) kondisi fisik dan substansi materi informasi akibat rentang waktu yang berpanjang; 4) faktor sosial budaya yang melatarbelakangi penciptaan karya-karya tulisan masa lampau yang tidak ada lagi atau tidak sama dengan latar sosial budaya pembacanya masa kini; 5) keperluan untuk mendapatkan hasil pemahaman yang akurat.

Filologi dipakai untuk menyebut ilmu yang berhubungan dengan studi teks yaitu studi yang dilakukan dalam rangka mengungkapkan hasil budaya yang tersimpan didalamnya. Pengertian demikian antara lain dapat dijumpai pada filologi di Negara Belanda. Sejalan dengan pengertian ini, di Prancis filologi mendapat pengertian sebagai studi suatu bahasa melalui dokumen tertulis dan studi mengenai teks lama beserta penurunan (transmisi)nya.

Studi Filologi di Indonesia, sampai kira-kira permulaan abad ke-20 ini, masih mengikuti konsep filologi dalam pengertian studi teks dengan tujuan melacak bentuk mula teks. Mulai akhir abad ke-20 studi filologi di Indonesia berkembang dengan mempertimbangkan kondisi teks dan naskah yang ada yang disadari tidak sama dengan kondisi teks dan naskah yang melahirkan disiplin filologi serta kehidupan pernaskahan yang ada dalam masyarakat pada waktu itu. 


\section{Objek Kajian Filologi}

Filologi berusaha mengungkapkan hasil budaya suatu bangsa melalui kajian bahasa Pada peninggalan dalam bentuk tulisan. Lahirnya ilmu filologi sebagai istilah bagi suatu bentuk studi, filologi diperlukan karena munculnya variasi-variasi dalam teks yang tersimpan dalam naskah. Gejala tersebut memperlihatkan bahwa dalam penyalinan naskah, teks senantiasa mengalami perubahan sehingga lahirlah wujud teks yang bervariasi. Dengan demikian adanya variasi-variasi untuk suatu informasi masa lampau yang terkandung dalam naskah itulah yang melahirkan kerja filologi. Dampak dikatakan bahwa kerja filologi didasarkan pada prinsip bahwa teks berupa dalam penurunannya. Jadi, filologi bekerja karena adanya sejumlah variasi.

Sejarah lahirnya filologi sebagai istilah, dapat diketahuai bahwa filologi mempunyai sasaran kerja yang berupa naskah. Ilmu yang berkaitan dengan naskah dan pernaskaan disebut kodikologi. Karena kodikologi adalah ilmu tentang kodeks (kata lain untuk naskah). Objek kajian filologi adalah teks, yaitu informasi yang terkandung dalam naskah yang sering disebut juga muatan naskah atau tekstologi. Tujuan kerja filologi terbagi menjadi dua yakni tujuan umum dan tujuan khusus. Tujuan umum, yaitu 1) mengungkapkan produk masa lampau melalui peninggalan tulisan; 2) Mengungkapkan fungsi peninggalan tulisan pada masyarakat penerimanya, baik pada masa lampau maupun pada masa kini; 3) Mengungkapkan nilai-nilai budaya masa lampau. Tujuan khusus adalah 1) Mengungkapkan bentuk mula teks yang tersimpan dalam peninggalan tulisan masa lampau; 2) Mengungkapkan sejarah perkembangan teks; 3) Mengungkapkan sambutan masyarakat terhadap suatu teks sepanjang penerimaanya; 4) menyajikan teks dalam bentuk yang terbaca oleh masyarakat masa kini, yaitu dalam bentuk suntingan.

\section{Pengaruh Bahasa pada Teks Kuno}

Bahasa yang mempengaruhi bahasa-bahasa naskah nusantara yaitu bahasa Sansekerta, Tamil, Arab, Persi, dan bahasa daerah yang serumpun dengan bahasa naskah. Pada naskah yang semula berupa teks lisan nampak adanya pengaruh 
bahasa barat. Karena pengaruh bahasa Tamil, Persi, dan Barat terhadap bahasa naskah sangat sedikit, maka untuk telaah teks atau pemahaman teks dipandang tidak diperlukan pendalaman bahasa-bahasa tersebut. Lain halnya dengan bahasa Sansekerta dan bahasa Arab. Kedua bahasa ini besar pengarunya terhadap bahasa naskah di Nusantara, sehingga untuk pemahaman teks, kedua bahasa ini perlu didalami.

Adapun pengaruh bahasa-bahasa tersebut adalah, (1) Bahasa Sansekerta Terutama untuk pengkajian naskah-naskah Jawa. Khususnya Jawa Kuno, sangat dituntut pengetahuan bahasa Sansekarta; (2) Bahasa Arab Pengetahuan bahasa Arab diperlukan untuk pengkajian naskah-naskah karena pengaruh Islam, khususnya yang berisi ajaran Islam dan tasawuf atau suluk. Dalam naskah yang demikian itu, banyak terlihat kata-kata, frase, kalimat, ungkapan, dan nukilannukilan dalam bahasa Arab bahkan kadang-kadang bagian teks tertentu, misal pendahuluan, disusun dalam bahasa Arab. Contoh naskah-naskah yang bersifat seperti tersebut di atas dalam sastra melayu antara lain adalah naskah-naskah karya Hamzah Fansuri, Syamsuddin Assamatrani, Nurddin Arraniri, Absirathal Mustaqim, dan Daqa'iqul Hurul. Dalam sastra Jawa antara lain ialah naskahnaskahh yang berjudul suluk, yakni Suluk Sukarsa, Suluk wujil.

Disisi lain terdapat ilmu dan faktor lain yang mempengaruhi naskah kuno diantaranya, (1) Paleografi adalah Ilmu yang meneliti tentang tulisan kuno diatas batu, logam, atau bahan lainnya. Paleografi mempunyai dua tujuan: pertama menyebarkan tulisan kuno kerena beberapa tulisan kuno sangat sulit dibaca; kedua menempatkan berbagai peninggalan tertulis dalam rangka perkembangan umum tulisanya dan atas dasar itu menentukan waktu dan tempat terjadinya tulisan tertentu; (2) Ilmu Sastra tentang cerita pahlawan Islam. Untuk menangani teksteks sastrawi, filologi memerlukan metode-metode pendekatan yang sesuai dengan sifat objeknya ialah metode pendekatan ilmu sastra; (3) munculnya agama Hindu, Buddha, dan Islam. Penjelajahan terhadap naskah-naskah Nusantara lewat katalog dan karya-karya ilmiah memberikan kesan bahwa naskah-naskah itu diwarnai oleh pengaruh oleh agama Hindu, Budha dan Islam; (4) Sejarah Kebudayaan. Dalam khazanah sastra Nusantara disamping diwarnai oleh pengaruh agama Hindu, Budha, dan Islam, juga memperlihatkan adanya pengaruh 
sastra klasik India, Arab, dan Persia. Pengaruh karya klasik India seperti Ramayana dan Mahabrata muncul dalam sastra lama nusantara misalnya dalam sastra jawa kuno. Ramayana dan Mahabhrata yang kemudian sebagian besar disadur ke dalam bahasa Jawa kuna, Jawa tengah, dan jawa baru. Kecuali itu, muncul pula kreasi baru yang diilhami oleh karya-karya klasik India atau karyakarya Jawa Kuno saduran karya klasik India; (5) Antropologi; karya karya-karya pujangga linguis yang sekarang tersimpan diperpustakaan Surakarta dan Yogyakarta tampak dikeramatkan seperti benda-benda pusaka; (6) Folklore merupakan ilmu yang relative baru karena semula dipandang sebagai bagian antropologi. Sebagai nama kolektif yang memperlihatkan jangkauan yang sangat luas, hampir menyentuh setiap aspek kehidupan tradisional. Folkor telah ada sejak pertengahan abad ke-19. Unsur-unsur budaya yang dirangkumnya secara garis besar dapat digolongkan menjadi dua, yaitu golongan unsur budaya yang materinya bersifat lisan dan golongan unsur budaya yang berupa upacara-upacara.

Termasuk golongan pertama adalah mitologi, linguis, cerita asal usul (dunia, nama, tempat, binatang, tanaman, dsb.), cerita pelupur lara, dongeng, mantra, tahayul, teka teki, pribahasa, tradisional. Termasuk golongan kedua adalah upacara-upacara yang mengeringi kelahiran, perkawinan, kematian. Dengan demikaian maka yang erat kaitannya dengan filologi adalah pada golongan mitologi. Golongan ini mencakup unsur-unsur budaya yang biasa disebut sastra lisan, terutama sastra lisan yang termasuk tulisan rakyat.

\section{METODE PENELITIAN}

Objek dalam penelitian ini adalah naskah kuno di Maluku Utara yakni yang berada didua lokasi penelitian yaitu di Kesultanan Ternate dan Kesultanan Tidore. Penelitian ini untuk menelusuri naskah-naskah kuno yang berada di dua lokasi penelitian tersebut.

Data dalam penelitian ini adalah naskah kuno yang berada di Kesultanan Ternate dan Kesultanan Tidore, yang dikumpulkan dengan teknik wawancara dan catat tentang hal-hal yang terkait dengan naskah. Teknik ini dilakukan secara 
berulang-ulang untuk mendapatkan data yang akurat. Tujuannya untuk mendapatkan dokumen yang berisi data. Teknik catat adalah pencatatan dari hasil pengamatan terkait naskah-naskah yang ditemukan. Setelah pencatatan data kemudian dikumpulkan dan diklasifikasi berdasarkan pada data yang ditemukan.

Sumber data dalam penelitian ini bersumber pada informan di lokasi penelitian yang mengetahui tentang seluk-beluk naskah-naskah kuno yang berada di Kesultanan Ternate dan Kesultanan Tidore.

Metode dokumentasi adalah salah satu teknik yang digunakan untuk mencari data mengenai hal-hal atau variabel yang berupa cetakan. Menurut Margono (2000: 18) metode dokumentasi adalah cara pengumpulan data melalui peninggalan tertulis seperti arsip-arsip termasuk juga buku-buku tentang pendapat, teori, dalil atau hukum-hukum dan lain-lain yang berhubungan dengan penelitian. Metode ini dipilih karena penulis ingin mendapatkan data tertulis mengenai persiapan peneliti dalam memahami objek penelitiannnya.

Metode analisis data suatu penelitian sangatlah penting guna mendapatkan hasil dari penelitian yang akan dilakukan. Metode yang dipakai untuk menganalisis data dalam penelitian ini adalah metode deskriptif kualitatif yaitu suatu metode dimana data-data yang diperoleh akan dipaparkan atau digambarkan bentuk kalimat (Arikunto, 1992: 207). Dalam penelitian ini bentuk data yang didapat akan diuraikan penjelasan atau kata-kata. Langka-langkah yang dilakukan dalam penelitian ini adalah:

Langkah-langkah yang dilakukan dalam analisis ini adalah:

a. Identifikasi

Untuk mengetahui data-data dalam penelitian ini, mengidentifikasi objek penelitian yaitu dengan cara mengidentifikasi atau memaparkan gambaran umum lokasi dimana naskah ditemukan.

b. Klasifikasi

Selanjutnya telaah memaparkan gambaran umum data yang didapatkan kemudian dikelompokan berdasarkan naskah yang ditemukan.

c. Interpretasi 
Dalam penelitian ini penulis akan menginterpretasi atau mendeskripsikan tentang isi naskah kuno yang ditemukan dari hasil penelitian.

\section{PEMBAHASA}

Dalam sejarah perkembangannnya, awal kemunculan ilmu filologi berawal pada sebuah kebudayaan Yunani kuno yang merupakan salah satu dasar pemikiran yang sangat besar pengaruhnya dalam kehidupan masyarakat barat pada umumnya. Semenjak kecil masyarakat barat dibiasakan dengan nama-nama dewa seperti Apollo, Pallas Athena, Zeus, Hera dan lain-lain. Memang para dewa dan pahlawan dalam legenda Yunani kuno itu merupakan sumber kehidupan bagi pikiran dan imaginasi orang barat, seperti halnya di Indonesia cerita wayang bagi masyarakat yang bertradisi Jawa. Para penulis Barat acap kali mengutip mitologi Yunani Kuno apalagi mereka memerlukan perumpamaan yang bisa lebih menjelaskan jalan pikiran mereka. Karena itu jelas sekali bahwa mereka yang ingin mengetahui secara lebih mendalam aspek-aspek tertentu dari masyarakat Barat, akan mendapat menfaat apabila mengetahui dasar-dasar kebudayaan Yunani kuno. Ilmu filologi pun juga berakar pada kebudayaan Yunani kuno.

Dalam sejarahnya, ilmu filologi tumbuh dan berkembang di kawasan kerajaan Yunani, yaitu di kota Iskandariyah di benua Afrika pantai utara. Dari kota ini filologi berkembang dan meluas di Eropa Daratan dan seterusnya ke bagian dunia yang lain. Awal kegiatan filologi di kota Iskandaria dilakukan oleh bangsa Yunani pada abad ke-3 S.M. bangsa ini berhasil membaca naskah-naskah Yunani lama, yang kira-kira mulai ditulis pada abad ke -8 S.M. dalam huruf Yunani kuno. Huruf ini berasal dari huruf bangsa Funasia. Naskah-naskah itu ditulis pada daun papirus dan merekam tradisi lisan. Mulai abad ke-8 s.d. ke- 3 S.M naskah itu berkali-kali disalin, maka wajarlah kalau mengalami perubahan dari bentuk aslinya.

Sesudah Iskandariyah jatuh ke dalam kekuasaan Romawi, kegiatan filologi berpindah ke Eropa Selatan, berpusat di kota Roma dan melanjutkan tradisi filologi Yunani atau meneruskan kegiatan mazhab Iskandariyah. Naskah Yunani lama tetap merupakan bahan telaah utama dan bahasa Yunani tetap digunakan. 
Pada abad ke-1 perkembangan tradisi Yunani berupa pembuatan resensi terhadap naskah-naskah tertentu, dan perkembangan ini berkelanjutan hingga pecahnya kerajaan Romawi pada abad ke-4 menjadi kerajaan Romawi Barat dan Romawi Timur. Peristiwa ini mempengaruhi perkembangan filologi selanjutnya. Filologi di Romawi Barat diarahkan kepada penggarapan naskah-naskah dalam bahasa Latin yang sejak abad ke-3 S.M. telah digarap secara filologi. Naskah-naskah latin itu berupa puisi dan prosa, antara lain tulisan Cocero dan Varro. Kegiatan ini mungkin mengikuti kegiatan filologi pada abad ke-3 S.M. di Iskandariyah dan isi naskah-naskah itu banyak mewarnai dunia pendidikan di Eropa pada abad-abad selanjutnya. Tradisi Latin inilah yang dikembangkan di kerajaan Romawi Barat dan bahasa Latin menjadi bahasa ilmu pengetahuan.

Sejak terjadiny Kristenisasi di Benua Eropa, kegiatan filologi di Romawi Barat dilakukan juga untuk telaah naskah-naskah keagamaan yang dilakukan oleh para pendeta. Sejak abad ke-4 teks sudah ditulis dalam bentuk buku yang disebut codex dan menggunakan bahan kulit binatang, terutama kulit domba, dikenal dengan nama perkamen (Belanda perkament dan Inggris perchment). Dalam bentuk codex, naskah dapat memakai halaman. Hingga menjadi mudah dibaca, dan bahan perkamen lebih bertahan lama dari pada bahan papirus.

\section{Pengaruh Islam: Naskah Kuno di Ternate}

Awal abad ke-I Masehi Selat Malaka dan kedua pulau yaitu Sumatera dan Semenanjung Malaysia sudah menjadi tumpuan perdagangan dan bisnis antarbangsa, diantaranya dari negeri-negeri Arab, negeri anak benua di India, dan Negeri Cina. Sebelum bandar-bandar niaga yang besar berbentuk di sekitar Selat Melaka, Sriwijaya sejak abad ke-7 menjadi pusat perdagangan, pelayaran dan pusat agama Budha di Nusantara. Dan melalui suatu proses yang sangat panjang untuk membangun hubungan dengan negara-negara asing melalui lingua franca yang dikenal dengan bahasa Melayu. Dari hubungan tersebut, terbentuklah pusatpusat perdagangan di sekitar Selat Melaka seperti Pasai pada abad ke-14, Malaka abad ke 15, Aceh abad ke-16, dan karena bahasa Melayu juga dikenal dengan bahasa dan tulisan Jawi. Tulisan Jawi telah mengakar di seluruh melayu nusantara 
dan berkembang dengan pesat serta dapat diterima oleh mayoritas penduduk setelah proses islamisasi terjadi.

Tulisan Arab-Melayu atau Arab-Jawi (Aceh: Jawoe) adalah bahasa Melayu Aksara Arab termasuk Indonesia di dalamnya. Teks ditulis dengan mempergunakan aksara Arab disebut Arab-Melayu atau Arab-Jawi, bukan ArabIndonesia karena istilah yang demikian lebih terkenal dan lebih luas di Kepulauan Melayu-Nusantara dibanding Indonesia.

Penulisan bahasa Melayu dengan abjad Arab, sudah dimulai sejak Islam dianut orang yang tersebar di Nusantara. Sehingga tulisan Arab-Melayu menjadi tulisan resmi masyarakat dan kerajaan-kerajaan Islam di kala itu. Dalam jangka waktu berabad-abad tulisan tersebut telah mewariskan banyak literature dan kaligrafi yang indah-indah pada situs-situs sejarah umum generasi saat ini.

Banyak teori dari berbagai sarjana yang memberi pendapat mengenai proses dan asal-usul islamisasi di Kepualauan Melayu-Nusantara. Para intelektual Aceh memiliki kesamaan dan perbedaan pendapat bahwa Islam masuk di Aceh sejak tahun $800 \mathrm{M}(173 \mathrm{H})$. Seorang pengembara dari I Tsing (I Ching) dalam pernyataannnya bahwa Islam hadir abad ke-7 sampai ke-8 Masehi yang telah merabah ke dunia Melayu, dalam pengembaranya pada abad awal Hijriah orangorang muslim sudah pernah mengunjungi Negeri Melayu. Dalam tulisannya pada tahun 671 M, dia mengunjungi Sriwijaya (San'fotdi) melaporkan bahwa ia pernah bertemu saudagar-saudagar muslim di Barus berasal dari Negara Arab dan Parsi. Perbedaan-perbedaan tersebut didasarkan pada sumber kajian yang berbeda, baik melalui artefak (arkeologis) maupun melalui catatan-catatan naskah kuno (filologis dan historis), namun keduanya berdasarkan tulisan beraksara Jawi. Kelompok yang pertama berdasarkan pada penemuan batu nisan yang dikenal dengan Kerajaan Pasai terletak di Minye Tujuh, Aceh Utara (Pasee), termaktub di batu nisan antara tahun 1290 sampai $1380 \mathrm{M}$.

Kelompok kedua (pengkaji Nusantara) menyimpulkan bahwa Islam sudah hadir di Nusantara jauh sebelum batu nisan di wilayah Pasai. Kelompok ini menyimpulkan bahwa melalui kajian manuskrip yang tersedia, baik naskah sejarah ataupun keagamaan seperti Bustan al-Salatin, Hikayat Aceh, Hikayat Raja-Raja Pasai, Dhur al-Manzum dan sebagainya yang ditulis dalam aksara 
Arab-Jawi. Hal ini menjadi bukti yang sangat valit bahwa sejak abad ke-13 M kerajaan Islam pertama di Kepulauan Melayu Nusantara telah muncul, yang berarti bahwa islamisasi secara resmi sudah berjalan. Dan dalam abad berikutnya islamisasi bergulir semakin luas ke tempat-tempat lain hingga mencakup seluruh Kepulauan Melayu Nusantara. Dengan demikian maka tumbuh pulalah jaringan timbal balik antara kedua kawasan tersebut, bukan antara wilayah sentral dengan peripheral, tetapi menjadi equal, baik jaringan dagang, jalur ibadah haji, kerjasama, dan jaringan ulama dalam bentuk hubungan murid dan guru. Munculnya hubungan tersebut didominasi oleh para intelektual dan pedagang sehingga lebih memudahkan dalam proses islamisasi yang diterima dengan tanpa kekerasan, sehingga seluruh khazanah adat budaya dan perilaku kehiduapan bertransformasi ke dalam corak Islam termasuk tulisan dan aksara.

Sebagimana yang sudah disinggung di atas bahwa Islam mulai berperan pada abad ke-13 M, peranan tersebut meliputi semua sisi kehidupan masyarakat dan mempengaruhi sisi-sisi budaya, adat istiadat dan keilmuan. Tradisi tulis menulis dan itelektual juga dipengaruhi oleh islamisai dari Arab, namun tidak keseluruhan 'karakter' Arab sebagai sumber Islam dapat menyerap dalam masyarakat Melayu (Nusantara). Pengaruh-pengaruh Arab tersebut juga ditemukan di Ternate Propinsi Maluku Utara. Terdapat penulisan naskah-naskah kuno dengan huruf arab yang ditemukan di Maluku Utara. Selain itu temuan arkeologi yang ditemukan pada batu-batu nisan dan bangunan-bangunan tua lainnya menggunakan bahasa arab. Maluku Utara tidak memiliki aksara maka naskah-naskah kuno yang ditemukan banyak menggunakan huruf Arab atau tulisan Arab. Naskah kuno yang ada di Maluku Utara dibawa oleh para missionaris yang datang dengan misi untuk menyiarkan agama Islam. Kedatangan mereka banyak membawa pengaruh-pengaruh di antaranya tradisi dan naskah tulisan tangan atau naskah kuno dengan tulisan Arab yang ditemukan di Keraton Kesultanan Ternate dan Kesultanan Tidore.

Naskah Kuno di Maluku Utara

Naskah Kuno: Mushaf di Kesultanan Ternate 
Salah satu naskah kuno yang ditemukan tersimpan di Kesultanan Ternate. Naskah kuno ini, disebut mushaf Alquran adalah naskah tulisan tangan yang tersimpan di Kesultanan Ternate. Menurut Ali (wawancara, 06/07: 2016) penjaga naskah kuno Kesultanan Ternata, menyampaikan bahwa naskah tersebut merupakan naskah tertua yang tersimpan di Kesultanan Ternate. diperkuat juga dengan keterangan yang dimuat dalam sebuah surat yang ditulis oleh katua Yayasan Festival Mesjid Istiqlal Jakarta kepada Sultan Ternate yang menyatakan bahwa usia naskah tersebut sudah mencapai 421 tahun. Sebagimana terlihat pada gambar naskah Mushaf berikut.

Ukuran bidang teks naskah kecil, hanya berukuran 22 x $11 \mathrm{~cm}$. Jumlah baris terdiri dari 13 per halaman, menggunakan kertas Eropa namun cap kertas dalam naskah ini tidak dapat terdeteksi dengan baik karena naskah sudah tua dan kategori korup atau rusak. Sisi kanan naskah berukuran 31 x 20 dan sisi kiri 5 x $10 \mathrm{~cm}$. Tinta yang digunakan untuk menulis berwarna hitam dan merah. Isi teks berwarna hitam tetapi dalam penulisan nama surat mushaf menggunakan tinta berwarna merah. Pemilihan warna yang dipakai tergantung pada penulis naskah awal. Menggunakan tanda bulat pada akhir tulisan ayat, tanda juz, tanda tajwid. Dan hadis-hadis keutamaan dalam membaca surah tertentu di awal pada setiap surat. Naskahnya masih memiliki iluminasi yang masih indah dan menggunakan pola tulisan yang sangat khas di bagian awal sampai akhir naskah. Iluminasi yang dikerjakan oleh penulis naskah mushaf memiliki keterampilan dan jiwa seni yang tinggi. Selain itu, ditepi halaman mushaf terdapat catatan yang disebut $q$ ira'at yang lengkap sedangkan dibagian akhir terdapat catatan yang disebut wakaf.

Secara visual naskah masih dapat dibaca dengan baik walaupun kondisi fisik naskahnya tidak begitu baik atau korup. Kondisi naskah saat ini, di bagian tepi sudah dimakan rayap, jilidnya sudah agak rusak, cover depan tidak ada. Namun naskah tersebut masih tersimpan di Ternate dan pada tempatnya yang berbeda-beda. Mushaf ini ada empat buah diantaranya dua tersimpan di Kesultanan Ternate tepatnya di kamar puji sultan atau ruangan khusus sultan yang diletakkan di atas mahkota sultan, dan kalau ada yang ingin melihatnya harus seizin sultan. Sedangkan yang lainnya masih tersimpan di Mesjid Sultan Ternate. 


\section{a. Naskah Kuno: Tulisan Tangan Sultan Ternate}

Naskah ini adalah tulisan tangan Sultan Ternate. Masih tersimpan dengan baik di Kesultanan Ternate. Tulisan Sultan Ternate ini adalah salah satu naskah kuno tertua kedua setelah tulisan tangan yang di tulis oleh Abu Hayat pada tahun 1522. Pihak kesultanan menyebut sebagai naskah Melayu Ternate. Tinta yang dipakai untuk menulis adalah tinta cair (tinta colo-colo), aksara yang dipakai adalah aksara Arab atau lebih dikenal oleh masyarakat Maluku Utara sebagai Arab gundul. Bahannya dari dari daun lontar dan hanya terdiri dari satu lembar. Menurut keterangan Ali (wawancara, 06/06: 2016), penjaga naskah bahwa isi daripada naskah ini adalah surat Sultan Ternate kepada Sultan Aceh. Namun sampai saat ini naskah ini tidak dapat diterjemahkan karena membutuhkan ahli dalam mengartikannya. Walaupun dapat dibaca oleh para pembaca yang memahami tentang penulisan Arab gundul.

\section{b. Naskah Kuno: Mushaf Berusia 800 Tahun}

Usia naskah sudah mencapai 800 tahun, merupakan salah satu naskah kuno tertua yang berada dikawasan Asia Tenggara. Saat ini naskah tersebut tersimpan di kesultanan Ternate. Bahan yang dipakai terbuat dari kulit kayu atau disebut dluwang. Dluwang atau kertas (dalam kamus Poerwadarminta) adalah kertas tetapi kertas yang dimaksud adalah kulit kayu. Dluwang atau dlancang dapat diartikan menjadi dua yakni, 1) kulit kayu yang dipakai baju para prajurit; dan 2) benda tipis yang lajim ditulisi, dibuat sebagai buku dan sebagainya (Pujiastuti, 1939: 38). Pernyataan ini benar, karena bahan baku dluwang adalah kulit kayu. bahan yang dipakai untuk menulis adalah disebut pudak dan tinta cair. Pudak atau biasa disebut ketaka atau cindaga adalah bunga pohon pandan (jenis pohon yang mirip dengan pohon nanas).

Pudak (bunga pohon pandan hutan) tersusun menurut lapisan, bunganya terbungkus oleh pelepah yang berbentuk lonjong dan salah satu ujungnya runcing. Pudak baru bisa terlihat jika pelepahnya mekar. Helai daun pudak panjang dan akan terlihat jika pelepahnya mekar. Helai daun pudak panjang dan berwarna putih. Inilah yang sering dipakai oleh para kawi sebagai bahan tulis dalam 
menulis syair ataupun lagu-lagu tradissional. Mushaf tersebut diatas, isinya ayat suci alquran 30 juz dan 114 surat. Mushaf ini juga dilapisi semacam kotak yang berbahan kayu. Mushaf Alquran ini dibawa pada masa Sultan Babullah pada abad ke-5.

\section{c. Naskah Kuno: Tulisan Tangan Orang Belanda}

Naskah yang sudah mencapai 50 tahun ini tersimpan di Kesultanan Ternate. Isi naskah tentang surat dan menggunakan aksara Arab. Naskah ditulis oleh bangsa kolonial Belanda yang ditujukan kepada Sultan Ternate. Naskah ini hanya satu lembar. Bahan yang digunakan untuk menulis adalah dengan menggunakan tinta hitam (tinta colo-colo) dan kertasnya berwarna kuning sebagaimana yang terlihat dalam naskah tersebut di atas.

\section{Naskah Kuno yang Tersimpan di Kesultanan Tidore}

\section{a. Naskah Kuno Berbentuk Al-quran}

Naskah kuno Al-quran tersimpan di kedaton Kesultanan Tidore. Secara fisik naskah ini sudah hancur dan sebagian isi teksnya sudah tidak bisa terbaca karena rusak/korup. Berdasarkan hasil wawancara (07: 17: 2016) bahwa usia naskah kuno tersebut tidak dapat diketahui dan bahan yang dipakai pun tidak diketahui oleh penjaga, karena orang yang mengetahui tentang naskah tersebut sedang tidak berada di tempat. Namun berdasarkan kajian filologi, bahwa secara fisik umur naskah sudah mencapai 500 tahun lebih. Bahan baku naskah dari kulit kayu atau dluwang. Jumlah naskah sangat tebal atau sekitar 800 lembar dan tidak terlihat kolofon dalam naskah tersebut karena naskah sudah korup.

\section{b. Naskah Kuno Buku Tembaga}

Masyarakat Tidore menyebutnya sebagai buku Tembaga sama sebutannya seperti buku Tembaga yang berada di Kesultanan Ternate, namun yang berbeda adalah kondisi buku Tembaga di Kesultanan Tidore sudah rusak karena dimakan zaman sebagaimana terlihat pada foto tersebut di atas. Buku tembaga ini ditulis 
sekitar pada tahun 1905. Bahan yang dipakai dari kulit kayu (dluwang), dan pena yang dipakai dalam menulis adalah dari pudak dan menggunakan tinta berwarna hitam yang dicampur dengan bahan pengawet (asam cuka), tujuannnya agar tidak mudah luntur dan menggunakan huruf arab. Isi naskah adalah tentang kisah para Sultan Tidore pada masa Sultan Zainal Abidin. Berikut gambar naskah yang kondisinya sudah rusak atau korup tampak dari dalam dan tampak dari luar/cover.

Naskah tersebut tersimpan di Keraton Kesultanan Tidore. Naskah aslinya setebal 800 ratus halaman, dan karena tidak terawat maka banyak lembaran yang sobek ,hilang dan bahkan rusak dimakan rayap. Saat ini ketebalan naskah tinggal 400 ratus lebar. Kolofon dalam naskah ini tidak terlihat dengan jelas disebabkan karena kondisi naskah sudah tua dan rusak atau korup.

\section{PENUTUP}

Penelitian ini menggunakan pendekatan filologi. Filologi adalah ilmu yang berbicara tentang seluk beluk naskah kuno yang ada di Nusantara. Penelitian ini difokuskan pada penelusuran naskah kuno yang tersimpan di Kesultanan Ternate dan Tidore. Kesultanan Ternate dan Tidore banyak menyimpan naskah-naskah kuno yang secara fisik kondisi naskah sangat memprihatinkan karena tidak terrawat sehingga naskah tersebut berada pada kategori rusak atau korup. Ditemukan bahwa di Kesultanan Ternate terdapat empat naskah yang tersimpan diantaranya, (1) Mushaf Al-quran. Usianya naskah sudah mencapai 421 tahun dan menggunakan aksara arab atau arab gundul; (2) Naskah tulisan tangan Sultan Ternate tentang surat yang ditujukan kepada Sultan Aceh. Naskah ini hanya satu lembar. Naskah ini ditulis oleh Abu Hayat pada tahun 1522; (3) Mushaf alquran yang usianya 800 tahun. Isi mushaf ini adalah ayat-ayat suci Al-quran; (4) Naskah kuno berbentuk surat yang ditulis oleh orang Belanda dan menggunakan aksara arab juga. Sementara di Kesultanan Tidore ditemukan dua jenis naskah kuno diantaranya, 1) Al-quran berusia 500 tahun, kondisi fisik naskahnya sudah lapuk atau korup. Isi tentang ayat-ayat suci Al-quran dan menggunakan aksara arab atau disebut arab gundul; (2) Naskah kuno buku tembaga. Isinya tentang 
kisah perjalanan para sultan Tidore pada masa Sultan Zainal Abidin. Keenam naskah kuno tersebut adalah kekayaan budaya Maluku Utara yang patuh untuk dijaga. Isi dan bahan yang digunakan dari kedua tempat ini berbeda-beda sebagaimana yang telah diuraikan di atas.

\section{Daftar Pustaka}

Abdullah, ImranTeuku. 1991. Hikayat Meukuta Alam. Jakarta: Intermasa

Baried Baroroh, Istanti Kun, dkk. 1994. Pengantar Teori Filologi. Yogyakarta:

Badan Penelitian dan Publikasi Fakultas (BPPF) Seksi Filologi, Fakultas Sastra dan Budaya Universitas Gadjah Mada.

Behreand, T.E. Pudjiastuti, Titik. 1997. Katalog Induk Naskah-Naskah Nusantara Jilid 3-B Fakultas Sastra Universitas Indonesia. Jakarta Pt: Yayasan Obor Indonesia.

Masinambow, Haenen Pual. 2002. Bahasa Indonesia dan Bahasa Daerah. Yayasan Obor Indonesia: Jakarta.

Pudjiastuti, Titik, 2006. Naskah dan Studi Naskah Sebuah Antologi. Bogor: AKADEMIA

Robson, O.S. 1994. Prinsip-prinsip Filologi Indonesia. Jakarta: RUL

Saktimulya, Ratna Sri (Tim Proyek). 2005. Katalog Naskah-Naskah Perputakaan Pura Pakualaman. Jakarta. Pt: Yayasan Obor Indonesia, The Toyota Foundation.

Zachrun Kun. 2008. Sambutan Hikayat Amir Hamzah (dalam Sejarah Melayu Hikayat Umar Umayah, dan Serat Menak. Yogyakarta: Seksi Penerbitan Fakultas Ilmu Budaya Universitas Gadja Mada. 


\title{
Sikap Pejabat Senior Universitas Khairun Dan Universitas Muhammadiyah Maluku Utara Terhadap Bahasa Inggris, Upaya Mendorong Kampus Bertaraf International Di Timur Indonesia
}

\author{
Sunaidin ode Mulae, S.S.,M.Hum ${ }^{1}$. Halida Nuria,S.S., M.Si ${ }^{2}$ \\ Pengajar pada Fakultas Sastra dan Budaya,Universitas Khairun
}

\begin{abstract}
This research aims to see the influence of attitudes and motivation of senior officials at Universitas Khairun and Universitas Muhammadiyah Maluku Utara towards English. This research uses descriptive-quantitative methode because the variables measured using numbers to determine attitudes. This research uses Likert scale in measuring attitude about senior officer phenomenon to English in academic world. With the Likert scale type, then the variables to be measured are described into performance indicators. Indicator achievement was used as a starting point to arrange the items of the instrument in the form of questions or statements. This study uses data collection techniques with questionnaires. Data analysis techniques are doing quantitatively-descriptive because of the quantitative data, the data analysis technique using statistical methods to determine the attitude. The results found in this study are attitude of senior officials at the Universitas Khairun and Universitas Muhammadiyah Maluku Utara towards English shows the frequency at the number Strongly Agree 0.12\%, Agree $0.49 \%$, Neutral $0.03 \%$, disagree $0.31 \%$, Strongly disagree $0.06 \%$. The percentage scores show that the attitude of senior officials at Universitas Khairun and Universitas Muhammadiyah Maluku Utara towards English is in enough category or conducive to English. Based on the analysis of the program WINKS SDA 7 also showed an average of 2.50 with a standard deviation of 0.74 and keofisien 0.300 . These scores if converted to the attitude criteria of language then the attitude of senior officials at the Universitas Khairun and Universitas Muhammadiyah Maluku Utara are on the average conducive with a percentage of $0.5 \%$. The analysis of WINKS SDA 7 program is consistent with manual calculation using the excel program that is the average of overall answer items by senior officials 2,61 with standard deviation of 0.35 , and the variability of 292.9 variation, so it can be assured that senior officials are in a position of conducive or enough.
\end{abstract}

Key words: The Attitude, Senior Officials, Universitas Khairun,Universitas Muhammadiyah Maluku Utara

\footnotetext{
${ }^{1}$ Dosen program studi Sastra Inggris \& Usaha Perjalanan Wisata, Fakultas Sastra dan Budaya Unkhair.

${ }^{2}$ Dosen Proram studi Sastra Inggris \& Usaha Perjalanan Wisata, Fakultas Sastra dan Budaya Unkhair.
} 


\section{PENDAHULUAN}

Belajar bahasa Inggris merupakan salah satu cara untuk meningkatkan sumber daya manusia masa kini dan mendorong pembangunan manusia Indonesia dalam menghadapi arus globalisasi masa depan, karena bahasa Inggris merupakan bahasa dunia yang digunakan oleh banyak negara. Bahasa Inggris juga menjadi alat komunikasi lintas budaya dunia sehingga penting untuk ditularkan ke masyarakat terutama kepada pemangku kepentingan, agar bahasa Inggris dapat dimasyarakatkan di lingkungan dimana mereka bekerja. Pemasyarakatan bahasa Inggris di lingkungan kerja menjadi penting untuk mengantisipasi era globalisasi dalam menghadapi arus Perdagangan Bebas ASEAN (AFTA) dan Masyarakat Ekonomi ASEAN (MEA) tahun 2016.

Penguasaan bahasa Inggris di kalangan pejabat senior menjadi penting untuk diterapkan sebagai salah satu kompetensi untuk menjadi bahan pertimbangan prestasi, karena bahasa kedua setelah bahasa Indonesia di dunia kerja adalah bahasa Inggris. Namun, di sisi lain, jangan sampai pemasyarakatan bahasa Inggris berubah menjadi linguistic imperialism (imperialisme linguistik). Untuk menyelesaikan persoalan itu, Suwarno (dalam jurnal wacana, 2006) mengusulkan jalan tengah berupa kebijakan trilogi bahasa, dengan mengembangkan kemampuan dalam tiga bahasa, yakni bahasa daerah sebagai bahasa pertama, bahasa Indonesia sebagai bahasa kedua, dan bahasa Inggris sebagai bahasa ketiga. Dengan begitu, bahasa Inggris dimasyarakatkan dengan tetap menjaga bahasa nasional serta identitas kultural bahasa Indonesia dan bahasa lokal.

Pengembangan trilogi bahasa tersebut dilakukan di berbagai sektor yakni keluarga, masyarakat, institusi kerja, lembaga pendidikan dan media massa. Agar melihat sejauhmana konsep pemasyarakatan dapat diterima oleh warga masyarakat, perlu dilakukan pemetaan sikap masyarakat pekerja terhadap penggunaan bahasa Inggris, karena penggunaan bahasa Inggris bagi pekerja akan banyak melahirkan kebijakan dan inovasi baru di dunia kerja. Maka, perlunya dicapai konsensus dengan para pejabat senior di lingkungan kerja yang menjadi role mode di masyarakat pekerja dan memiliki perpaduan berbagai sifat yang memungkinkannya mempengaruhi orang lain dalam membuat suatu kebijakan (Mar'at dalam Jurnal wacana, 2006). Sehingga, peran pemimpin merupakan salah satu kunci terwujudnya transformasi sosial pada lingkungan masyarakat pekerja.

Memetakan sikap masyarakat pekerja atau pejabat senior terhadap bahasa Inggris di kalangan penentu kebijakan tentunya untuk mendapatkan gambaran yang lebih komprehensif dalam penempatan pejabat di institusi kerja masingmasing. Agar perolehan bahasa kedua dan bahasa asing itu digunakan, maka perlu dilihat pengaruh beberapa faktor sosial dan psikologi, di antaranya faktor sikap positif terhadap diri sendiri, sikap positif terhadap bahasa target, dan sikap positif terhadap kelompok pengguna bahasa target.

Kajian Suwarno, Kartini dan Darnoko (dalam Jurnal Wacana, 2006) menunjukan korelasi yang signifikan antara sikap terhadap bahasa Inggris dan penguasaan bahasa Inggris dalam dunia kerja sangat mendorong kemajuan kepribadian pejabat dalam membuat kebijakan. Pandangan peneliti yang dikemukakan tersebut memberikan alasan bahwa penguatan bahasa Inggris pada pejabat senior di dunia kerja sangat diperlukan. Banyak faktor yang membuat 
bahasa Inggris tidak diminati atau digunakan di lingkungan tempat bekerja para pejabat senior, diantaranya, (1) tidak ada kebijakan yang lebih baik dalam penggunaan bahasa Inggris; (2) tidak ada regulasi dan instruksi pimpinan bahwa penggunaan bahasa Inggris di lingkungan tempat bekerja menjadi penting untuk para pegawai; (3) terdapat kecenderungan negatif bahwa bahasa Inggris dapat memperlambat lajunya percepatan bahasa nasional dan bahasa lokal; (4) terdapat pandangan keliru bahwa pengetahuan bahasa Inggris di lingkungan kerja tidak terlalu penting.

Berdasarkan fenomena umum tersebut di atas, peneliti mencoba merumuskan penelitiannya pada pejabat senior kampus di provinsi Maluku Utara yakni Universitas Khairun dan Universitas Muhamadiyah Maluku Utara. Peneliti berasumsi bahwa sikap pejabat senior di dua kampus tersebut terhadap bahasa Inggris belum maksimal. Problema ini dapat di temui hampir sebagian besar penempatan pejabat senior di dua institusi itu, tidak membutuhkan pengetahuan bahasa Inggris sebagai prasyarat dalam menentukan posisi jabatan. Padahal, dua kampus tersebut merupakan kampus yang sangat berperan aktif dalam mendorong pembangunan sumber daya manusia di Maluku Utara. Pembangunan sumber daya manusia Maluku Utara membutuhkan kompetensi dasar untuk dapat bersaing dengan sumber daya manusia di daerah atau kampus lain yang mempunyai visi dan misi bertaraf internasional di Indonesia.

Penelitian ini mengangkat permasalahan bagaimanakah sikap pejabat senior Universitas Khairun dan Universitas Muhammadiyah Maluku Utara terhadap bahasa Inggris dalam membuat kebijakan strategis untuk mewujudkan kampus bertaraf internasional di Maluku Utara. Berdasarkan permasalahan tersebut penelitian ini menggunakan konsep Likert dalam mengharuskan subjek yang di survei untuk menentukan sikap terhadap suatu pernyataan dengan memilih salah satu di antara 5 pilihan sikap seperti sangat setuju (SS), setuju (S), tidak setuju (TS), sangat tidak setuju (STS), dan tidak memiliki sikap (Tms). Pilihan dengan cara memberi tanda cek list $[\sqrt{ }] 1,2,3,4$ dan 0 untuk menunjukan sikap terhadap pernyataan.

\section{METODE PENELITIAN}

Penelitian ini menjelaskan dan menganalisis sikap pejabat terhadap bahasa Inggris. Sehingga penelitian ini menggunakan desain penelitian kuantitatif dan kualitatif dengan metode analisi data Statistik deskripsi. Penelitian ini menggunakan skala Likert untuk mengukur sikap pejabat senior secara spesifik yang selanjutnya disebut sebagai variabel penelitian. Dengan skala Likert maka variabel yang akan diukur diuraikan menjadi indikator capaian variabel. Indikator capaian itu dijadikan sebagai titik tolak untuk menyusun item-item instrumen yang dapat berupa pertanyaan atau pernyataan.

Dalam pengumpulan data dikembangkan instrumen penelitian berupa kuesioner dan wawancara. Kuesioner berisikan pertanyaan-pertanyaan untuk menjaring informasi atau data yang diperlukan dalam penelitian yang ditujukan kepada responden yang terkait dalam penelitian ini. Wawancara dilakukan kepada beberapa pejabat senior kampus dan dosen yang dapat mendukung data penelitian 
ini. Wawancara ini dilakukan untuk melengkapi data yang tidak dapat dijaring melalui instrumen penelitian.

Populasi yang digunakan dalam penelitian ini terdiri atas pejabat senior kampus berjumlah 30 orang, yang terbagi pejabat di Universitas Khairun berjumlah 15 orang, dan pejabat senior Universitas Muhammadiyah berjumlah 15 orang. Untuk menentukan sampel maka menggunakan probability sampling yakni pengambian sampel yang memberikan peluang yang sama bagi setiap unsur anggota populasi untuk dipilih menjadi anggota sampel.

Bahwa penelitian ini bertitik tolak dari item-item instrumen dalam bentuk pertanyaan. Maka kategori penelitian adalah penelitian kuantitatif-kualitatif sehingga dalam analisis data menggunakan teknik statistik deskripsi yang digunakan untuk menganalisis data sampel dan hasilnya tidak ingin membuat simpulan yang berlaku untuk populasi dimana sample diambil. Dalam analisis data menggunakan statistik deskriptif tidak ada uji signifikan, tidak ada taraf kesalahan, karena peneliti tidak bermaksud membuat generalisasi, sehingga tidak ada kesalahan generalisasi.

\section{HASIL PENELITIAN DAN PEMBAHASAN}

Sikap pejabat senior Universitas Khairun dan Universitas Muhammadiyah Maluku Utara terhadap bahasa Inggris terungkap melalui jawaban dari responden dengan 40 pernyataan/pertanyaan yang ada pada angket sikap. Berdasarkan data yang telah di analisis diperoleh bahwa tentang sikap pejabat terhadap bahasa Inggris di Universitas Khairun dan Universitas Muhammadiyah Maluku Utara menunjukan pada frekuensi yang hampir sama. 40 buah pernyataan/pertanyaan yang disuguhkan kepada pejabat senior, dalam hal ini pejabat yang masih memegang jabatan seperti Pembantu Rektor, Dekan, Pembantu Dekan, Ketua Program Studi, Sekretaris Prodi, dan Ketua laboratorium fakultas.

Pada 40 pernyataan/pertanyaan tersebut terbagi empat indikator. Indikator -indikator pernyataan/pertanyaan itu adalah indikator sikap suka (S) terhadap bahasa inggris atau sikap positif termuat dalam item nomor 1, 2, 3, 4, 5, 6, 28, 29, 30, 31, dan 32. Kemudian, Indikator sikap sangat suka (SS) terhadap bahasa inggris atau sikap sangat positif dan sikap kesungguhan dalam menggunakan bahasa inggris termuat pada item nomor 10, 11, 12, 13, 14, 15, 16, 20, 21, 34, 36, 37, 38 dan 39. Indikator sikap suka terhadap bahasa inggris atau tidak memiliki sikap (Tms) untuk pernyataan/pertanyaan bahwa bahasa inggris dapat dipersyaratan sebagai penempatan pejabat di kampus, seperti Rektor, Pembantu Rektor, Dekan, Pembantu Dekan, ketua Program Studi dan ketua Laboratorium, sikap ini termuat pada item 22, 23, 24, 25, 26, 27, 33, 35, dan 40. Indikator sikap tidak suka (TS) terhadap bahasa inggris, atau sikap tidak setuju (STS) pejabat di kampus terhadap bahasa inggris, pernyataan ini mengandung negatif termuat item nomor 7, 8, 9, 17, 18 dan 19.

Pda frekuensi sikap pejabat senior terhadap bahasa Inggris di Universitas Khairun dan Universitas Muhammadiyah Maluku Utara terungkap melalui analisis jawaban 40 item peryataan/pertanyaan. Dari 40 pejabat yang di survei tergambar pada Tabel.1, pada dalam tabel.1, tersebut menunjukan bahwa frekeuensi sikap pejabat senior di Universitas Khairun dan Universitas Muhammadiyah Maluku Utara terhadap bahasa inggris sebagai berikut: 
Nilai positif sikap pejabat terhadap bahasa Inggris yang memilih pernyataan/pertanyaan Sangat Setuju (SS) sebanyak 186 poin. Nilai positif sikap pejabat terhadap bahasa Inggris yang memilih pernyataan/pertanyaan Setuju (S) sebanyak 786 poin. Nilai biasa-biasa atau netral $(\mathrm{N})$ atau tidak memiliki sikap (Tms), sikap pejabat terhadap bahasa Inggris sebanyak 41 poin. Nilai negatif sikap pejabat terhadap bahasa Inggris yang memilih pernyataan/pertanyaan tidak setuju (TS) sebanyak 500 poin. Nilai negatif sikap pejabat terhadap bahasa Inggris yang memilih pernyataan/pertanyaan sangat tidak setuju (STS) sebanyak 90 poin.

Pernyataan/pertanyaan sikap pejabat senior di Universitas Kharun dan Universitas Muhammadiyah Maluku Utara terhadap bahasa Inggris dari 40 pejabat yang disurvei semuanya memilih sikap mengarah pada cendurung cukup atau kondusif dalam menggunakan atau mempersyaratkan bahasa Inggris untuk posisi jabatan Rektor, Pembantu Rektor, Dekan, Pembantu Dekan, Ketua Program Studi, Sekretaris Program Studi, Ketua laboratorium maupun kelulusan mahasiswa.

Bahwa keseluruhannya memiliki total skor 1600 poin yang tergabung dari seluruh item pernyataan/pertanyaan positif dan negatif. Sehingga seluruh pejabat senior yang dinilai dalam pengisian angket rata-rata menunjukan cukup dengan proporsi setiap item pernyataan adalah Sangat Setuju 0,12 \%, Setuju 0,49\%, Netral $0,03 \%$, tidak setuju $0,31 \%$, Sangat tidak setuju 0,06 \%. Gambaran frekuensi (f) dan Proporsi (P) atau resonansi jawaban tersebut terdapat pada tabel.1, sebagai berikut:

Tabel 1. Frekuensi Kriteria Sikap Bahasa

Pejabat senior Unkhair dan UMMU terhadap bahasa Inggris

\begin{tabular}{|c|c|c|c|c|c|c|c|c|c|c|c|}
\hline \multirow{2}{*}{ NO. } & \multicolumn{9}{|c|}{ FREKUENSI ( $)$} & \multicolumn{5}{|c|}{ PROPORSI (P) } & \multicolumn{1}{|c|}{ S } \\
\cline { 2 - 13 } & SS & S & N & TS & STS & Jum Res & SS & S & N & TS & STS \\
\hline 1 & 17 & 22 & 1 & 0 & 0 & 40 & 0,43 & 0,55 & 0,03 & 0,00 & 0,00 \\
\hline 2 & 12 & 24 & 2 & 2 & 0 & 40 & 0,30 & 0,60 & 0,05 & 0,05 & 0,00 \\
\hline 3 & 2 & 13 & 1 & 21 & 3 & 40 & 0,05 & 0,33 & 0,03 & 0,53 & 0,08 \\
\hline 4 & 2 & 17 & 1 & 18 & 2 & 40 & 0,05 & 0,43 & 0,03 & 0,45 & 0,05 \\
\hline 5 & 0 & 11 & 1 & 24 & 4 & 40 & 0,00 & 0,28 & 0,03 & 0,60 & 0,10 \\
\hline 6 & 10 & 27 & 1 & 2 & 0 & 40 & 0,25 & 0,68 & 0,03 & 0,05 & 0,00 \\
\hline 7 & 0 & 3 & 1 & 26 & 10 & 40 & 0,00 & 0,08 & 0,03 & 0,65 & 0,25 \\
\hline 8 & 0 & 1 & 2 & 26 & 11 & 40 & 0,00 & 0,03 & 0,05 & 0,65 & 0,28 \\
\hline 9 & 0 & 1 & 2 & 28 & 9 & 40 & 0,00 & 0,03 & 0,05 & 0,70 & 0,23 \\
\hline 10 & 1 & 6 & 2 & 23 & 8 & 40 & 0,03 & 0,15 & 0,05 & 0,58 & 0,20 \\
\hline 11 & 0 & 10 & 0 & 27 & 3 & 40 & 0,00 & 0,25 & 0,00 & 0,68 & 0,08 \\
\hline 12 & 0 & 12 & 2 & 24 & 2 & 40 & 0,00 & 0,30 & 0,05 & 0,60 & 0,05 \\
\hline 13 & 3 & 19 & 0 & 16 & 2 & 40 & 0,08 & 0,48 & 0,00 & 0,40 & 0,05 \\
\hline
\end{tabular}




\begin{tabular}{|c|c|c|c|c|c|c|c|c|c|c|c|}
\hline 14 & 3 & 13 & 1 & 21 & 2 & 40 & 0,08 & 0,33 & 0,03 & 0,53 & 0,05 \\
\hline 15 & 7 & 31 & 0 & 2 & 0 & 40 & 0,18 & 0,78 & 0,00 & 0,05 & 0,00 \\
\hline 16 & 7 & 32 & 0 & 1 & 0 & 40 & 0,18 & 0,80 & 0,00 & 0,03 & 0,00 \\
\hline 17 & 0 & 3 & 2 & 31 & 4 & 40 & 0,00 & 0,08 & 0,05 & 0,78 & 0,10 \\
\hline 18 & 3 & 14 & 1 & 20 & 2 & 40 & 0,08 & 0,35 & 0,03 & 0,50 & 0,05 \\
\hline 19 & 1 & 14 & 2 & 20 & 3 & 40 & 0,03 & 0,35 & 0,05 & 0,50 & 0,08 \\
\hline 20 & 5 & 26 & 3 & 4 & 2 & 40 & 0,13 & 0,65 & 0,08 & 0,10 & 0,05 \\
\hline 21 & 4 & 14 & 2 & 16 & 4 & 40 & 0,1 & 0,35 & 0,05 & 0,40 & 0,10 \\
\hline 22 & 5 & 15 & 0 & 17 & 3 & 40 & 0,13 & 0,38 & 0,00 & 0,43 & 0,08 \\
\hline 23 & 5 & 21 & 0 & 11 & 3 & 40 & 0,13 & 0,53 & 0,00 & 0,28 & 0,08 \\
\hline 24 & 6 & 19 & 0 & 11 & 4 & 40 & 0,15 & 0,48 & 0,00 & 0,28 & 0,10 \\
\hline 25 & 1 & 17 & 0 & 19 & 3 & 40 & 0,03 & 0,43 & 0,00 & 0,48 & 0,08 \\
\hline 26 & 4 & 21 & 3 & 11 & 1 & 40 & 0,1 & 0,53 & 0,08 & 0,28 & 0,03 \\
\hline 27 & 9 & 30 & 1 & 0 & 0 & 40 & 0,23 & 0,75 & 0,03 & 0,00 & 0,00 \\
\hline 28 & 10 & 29 & 0 & 1 & 0 & 40 & 0,25 & 0,73 & 0,00 & 0,03 & 0,00 \\
\hline 29 & 12 & 28 & 0 & 0 & 0 & 40 & 0,3 & 0,7 & 0,00 & 0,00 & 0,00 \\
\hline 30 & 6 & 30 & 0 & 2 & 2 & 40 & 0,15 & 0,75 & 0,00 & 0,05 & 0,05 \\
\hline 31 & 8 & 31 & 1 & 0 & 0 & 40 & 0,2 & 0,78 & 0,03 & 0,00 & 0,00 \\
\hline 32 & 5 & 29 & 2 & 4 & 0 & 40 & 0,13 & 0,73 & 0,05 & 0,10 & 0,00 \\
\hline 33 & 6 & 30 & 1 & 3 & 0 & 40 & 0,15 & 0,75 & 0,03 & 0,08 & 0,00 \\
\hline 34 & 4 & 26 & 0 & 9 & 1 & 40 & 0,1 & 0,65 & 0,00 & 0,23 & 0,03 \\
\hline 35 & 1 & 20 & 1 & 18 & 0 & 40 & 0,03 & 0,5 & 0,03 & 0,45 & 0,00 \\
\hline 36 & 3 & 31 & 1 & 5 & 0 & 40 & 0,08 & 0,78 & 0,03 & 0,13 & 0,00 \\
\hline 37 & 11 & 26 & 1 & 2 & 0 & 40 & 0,28 & 0,65 & 0,03 & 0,05 & 0,00 \\
\hline 38 & 9 & 29 & 1 & 1 & 0 & 40 & 0,23 & 0,73 & 0,03 & 0,03 & 0,00 \\
\hline 39 & 2 & 19 & 1 & 17 & 1 & 40 & 0,05 & 0,48 & 0,03 & 0,43 & 0,03 \\
\hline 40 & 2 & 19 & 1 & 17 & 1 & 40 & 0,05 & 0,48 & 0,03 & 0,43 & 0,03 \\
\hline & 186 & 783 & 41 & 500 & 90 & 1600 & 0,12 & 0,49 & 0,03 & 0,31 & 0,06 \\
\hline
\end{tabular}

Berdasarkan tabel.1, di atas skor yang diperoleh frekuensi sikap pejabat Universitas Khairun dan Universitas Muhammadiya Maluku Utara terhadap bahasa Inggris secara keseluruhan dapat di ukur untuk melihat posisi kriteria sikap pejabat terhadap bahasa inggris menggunakan rumus hitung sebagai berikut. 
Rumus:

$$
\begin{aligned}
& \text { (f) } \frac{\sum \text { Skor } \quad(s)}{\sum \text { Responden }(\mathrm{n})}=\frac{1600}{40}=40 \\
& \text { Ket: } \mathrm{S}=\text { Skor keseluruhan item soal } \\
& \mathrm{N}=\text { Jumlah responden }
\end{aligned}
$$

Analisis nilai frekuensi sikap pejabat di atas menunjukan bahwa sikap pejabat senior di Universitas Khairun dan Universitas Muhammadiyah Maluku Utara pada angka 40, angka ini dapat dipastikan bahwa sikap pejabat senior di dua kampus tersebut mengarah pada posisi cukup atau kondusif dalam menggunakan bahasa Inggris secara aktif di ruang kantor, ruang program studi, lingkungan fakultas maupun menjadi salah satu prasyarat untuk kelulusan mahasiswa. Oleh karena itu, sikap pejabat senior rata-rata setiap item pernyataan/pertanyaan mempunyai jawaban pada level cukup dan kondusif untuk membuat kebijakan di dalam memberlakukan bahasa Inggris menjadi aktif di ruang-ruang kelas maupun lingkungan kampus.

Namun, kalau dilihat berdasarkan jawaban setiap item pernyataan/pertanyaan pada setiap indikator seperti Suka, Sangat Suka, Tidak Suka, Sangat tidak suka terhadap bahasa Inggris oleh Pejabat Senior di Universitas Khairun dan Universitas Muhammadiyah akan menunjukan nilai sikap rerata sangat variatif. Sehingga, kalau dibandingkan dengan kriteria sikap bahasa pada tabel.1, akan berbeda nilainya pada setiap item jawaban yang menuju pada pemaknaan rerata seperti amat kondusif, kondusif, netral, tidak kondusif dan amat tidak kondusif. Untuk mengetahui itu semua maka akan di analisis berdasarkan item indikator pernyataan/ pertanyaan.

Adapun analisis sikap dalam setiap item pernyataan/pertanyaan dalam bentuk nilai pemaknaan rerata untuk sikap pejabat senior di Universitas Khairun dan Universitas Muhammadiyah Maluku Utara dapat ditunjukan dengan indikator- indikator pertanyaan dan pernyataan. Untuk dapat diketahui indikatorindikator tersebut maka dilakukan hitung seperti pada tabel.2, tabel.3, tabel.4 dan tabel.5.

Berikut hasil hitung terhadap indikator-indikator sikap sangat suka atau sikap positif pejabat senior di Universitas Khairun (Unkhair) dan Universitas Muhammadiyah Maluku Utara (UMMU).

Tabel 2. Sikap Sangat Suka/Sikap Positif (SS)

Pejabat Unkhair dan UMMU Terhadap Bahasa Inggris

\begin{tabular}{|c|c|c|c|c|c|c|c|c|c|c|c|c|c}
\hline & \multicolumn{10}{c|}{ Indikator Sikap suka bahasa Inggris atau sikap positif oleh pejabat senior } & \multicolumn{1}{c}{} \\
UNKHAIR dan UMMU \\
No & \multicolumn{10}{|c|}{ item pernyataan suka/positif terhadap bahasa inggris } & $\begin{array}{c}\text { Perse } \\
\mathrm{n} \%\end{array}$ \\
\hline Resp & 1 & 2 & 3 & 4 & 5 & 6 & 28 & 29 & 30 & 31 & 32 & Skor & \\
\hline 1 & 4 & 3 & 1 & 2 & 1 & 4 & 3 & 3 & 3 & 3 & 3 & 30 & 68,1 \\
\hline 2 & 3 & 3 & 3 & 4 & 3 & 3 & 3 & 4 & 3 & 3 & 3 & 35 & 79,5 \\
\hline 3 & 4 & 4 & 4 & 4 & 3 & 4 & 4 & 4 & 3 & 3 & 4 & 41 & 93,1 \\
\hline
\end{tabular}




\begin{tabular}{|c|c|c|c|c|c|c|c|c|c|c|c|c|c|}
\hline 4 & 3 & 3 & 3 & 3 & 3 & 3 & 3 & 3 & 3 & 3 & 3 & 33 & 75 \\
\hline 5 & 3 & 3 & 2 & 2 & 2 & 3 & 3 & 4 & 3 & 3 & 3 & 31 & 70,4 \\
\hline 6 & 3 & 3 & 3 & 2 & 1 & 3 & 4 & 3 & 3 & 3 & 0 & 28 & 63,6 \\
\hline 7 & 3 & 3 & 2 & 3 & 2 & 3 & 3 & 3 & 3 & 3 & 3 & 31 & 70,4 \\
\hline 8 & 3 & 2 & 1 & 1 & 1 & 3 & 3 & 3 & 2 & 3 & 2 & 24 & 54,5 \\
\hline 9 & 4 & 4 & 4 & 3 & 2 & 3 & 4 & 4 & 4 & 3 & 3 & 38 & 86,3 \\
\hline 10 & 4 & 4 & 3 & 2 & 2 & 3 & 3 & 3 & 3 & 3 & 3 & 33 & 75 \\
\hline 11 & 3 & 3 & 2 & 2 & 3 & 3 & 3 & 3 & 3 & 3 & 3 & 31 & 70,4 \\
\hline 12 & 3 & 3 & 2 & 2 & 2 & 3 & 3 & 3 & 3 & 3 & 3 & 30 & 68,1 \\
\hline 13 & 4 & 4 & 2 & 3 & 2 & 3 & 3 & 3 & 3 & 3 & 3 & 33 & 75 \\
\hline 14 & 4 & 3 & 2 & 3 & 2 & 4 & 4 & 4 & 4 & 4 & 3 & 37 & 84,0 \\
\hline 15 & 3 & 3 & 2 & 2 & 2 & 3 & 3 & 3 & 3 & 3 & 2 & 29 & 65,9 \\
\hline 16 & 4 & 4 & 2 & 3 & 2 & 4 & 4 & 4 & 4 & 4 & 3 & 38 & 86,3 \\
\hline 17 & 3 & 3 & 1 & 2 & 2 & 3 & 3 & 3 & 3 & 3 & 3 & 29 & 65,9 \\
\hline 18 & 4 & 4 & 3 & 3 & 3 & 3 & 3 & 3 & 3 & 4 & 3 & 36 & 81,8 \\
\hline 19 & 3 & 3 & 3 & 3 & 3 & 3 & 3 & 3 & 3 & 3 & 3 & 33 & 75 \\
\hline 20 & 3 & 3 & 2 & 2 & 3 & 3 & 3 & 3 & 3 & 3 & 3 & 31 & 70,4 \\
\hline 21 & 4 & 3 & 2 & 3 & 2 & 4 & 3 & 3 & 3 & 3 & 3 & 33 & 75 \\
\hline 22 & 3 & 3 & 2 & 2 & 2 & 3 & 2 & 3 & 3 & 3 & 3 & 29 & 65,9 \\
\hline 23 & 3 & 3 & 2 & 2 & 2 & 2 & 3 & 3 & 3 & 3 & 3 & 29 & 65,9 \\
\hline 24 & 4 & 4 & 1 & 1 & 1 & 4 & 4 & 4 & 4 & 4 & 4 & 35 & 79,5 \\
\hline 25 & 4 & 4 & 1 & 3 & 2 & 4 & 3 & 4 & 4 & 4 & 3 & 36 & 81,8 \\
\hline 26 & 4 & 4 & 3 & 3 & 2 & 4 & 4 & 4 & 3 & 3 & 2 & 36 & 81,8 \\
\hline 27 & 4 & 3 & 3 & 3 & 3 & 3 & 3 & 3 & 3 & 3 & 3 & 34 & 77,2 \\
\hline 28 & 3 & 0 & 2 & 2 & 3 & 2 & 4 & 4 & 4 & 4 & 3 & 31 & 70,4 \\
\hline 29 & 3 & 3 & 2 & 2 & 2 & 3 & 3 & 3 & 3 & 3 & 3 & 30 & 68,1 \\
\hline 30 & 4 & 3 & 3 & 2 & 2 & 3 & 3 & 4 & 1 & 3 & 4 & 32 & 72,7 \\
\hline 31 & 3 & 3 & 3 & 2 & 2 & 3 & 3 & 3 & 3 & 3 & 3 & 31 & 70,4 \\
\hline 32 & 4 & 4 & 3 & 3 & 3 & 4 & 4 & 3 & 3 & 3 & 3 & 37 & 84,0 \\
\hline 33 & 4 & 3 & 1 & 3 & 2 & 4 & 3 & 3 & 3 & 3 & 3 & 32 & 72,7 \\
\hline 34 & 3 & 2 & 2 & 2 & 2 & 3 & 3 & 3 & 3 & 3 & 3 & 29 & 65,9 \\
\hline 35 & 3 & 4 & 2 & 2 & 2 & 3 & 3 & 3 & 3 & 3 & 3 & 31 & 70,4 \\
\hline 36 & 3 & 3 & 2 & 2 & 2 & 3 & 3 & 3 & 2 & 3 & 3 & 29 & 65,9 \\
\hline 37 & 0 & 0 & 0 & 0 & 0 & 0 & 3 & 3 & 1 & 0 & 0 & 7 & 15,9 \\
\hline 38 & 3 & 3 & 2 & 3 & 2 & 3 & 3 & 3 & 3 & 3 & 2 & 30 & 68,1 \\
\hline 39 & 3 & 3 & 3 & 3 & 2 & 3 & 3 & 3 & 3 & 4 & 4 & 34 & 77,2 \\
\hline 40 & 4 & 4 & 3 & 3 & 3 & 3 & 4 & 4 & 3 & 4 & 4 & 39 & 88,6 \\
\hline & & & 2,22 & 2,42 & 2,12 & 3,12 & 3,22 & & & 3,12 & & 31,87 & \\
\hline Rata & 3,35 & 3,1 & 5 & 5 & 5 & 5 & 5 & 3,3 & 3 & 5 & 2,875 & 5 & 72,4 \\
\hline STD & 0,73 & & 0,86 & 0,78 & 0,68 & 0,72 & 0,47 & 0,46 & 0,64 & 0,64 & & & \\
\hline $\mathrm{EV}$ & 5 & 0,900 & 1 & 0 & 6 & 2 & 9 & 4 & 0 & 7 & 0,822 & & \\
\hline & & & & & \multicolumn{8}{|c|}{ Rata-rata keseluruhan item instrumen } & 79,68 \\
\hline & & & & & \multicolumn{8}{|c|}{$\begin{array}{l}\text { Standar Deviasi (Kerapatan/keragaman setiap } \\
\text { orang) }\end{array}$} & 5,27 \\
\hline & & & & & \multicolumn{8}{|c|}{$\begin{array}{l}\text { Keofisien variasi (Melihat kerapatan/semakin } \\
\text { rapat semakin baik) }\end{array}$} & 13,73 \\
\hline
\end{tabular}


Tabel di atas menunjukan bahwa setiap item pertanyaan/pernyataan sikap suka terhadap bahasa Inggris, rata-rata keseluruhan jawaban yang di dapat dari pejabat senior di Universitas Khairun dan Universitas Muhammadiyah Maluku Utara yakni 31,876 atau 72,4 persen atau setiap item menunjukan setuju (S) dan tidak setuju (TS), dengan standar deviasi atau keragaman jawaban setiap pejabat dalam memberikan respon jawaban terhadap bahasa Inggris adalah 5,27 persen yang pada setiap item pernyataan dan pertanyaan menunjukan 0,735 sampai dengan 0,900 skor. Skor ini menunjukan bahwa keragaman respon jawaban dalam menerapkan bahasa Inggris di ruang-ruang kelas maupun ruang kantor cukup rapat dan ketat pada setiap orang. Sedangkan, keofisien atau kerapatan jawaban setiap pejabat dalam melihat bahasa Inggris menunjukan pada angka 13,73 persen.

Pada indikator sikap suka terhadap bahasa inggris oleh pejabat senior di Universitas Khairun dan Universitas Muhammadiyah Maluku Utara menunjukan bahwa amat tidak kondusif atau setuju dan tidak setuju dalam menerapkan bahasa Inggris di ruang-ruang kelas dan ruang kantor. Hanya saja pada keragaman setiap jawaban menunjukan angka 79,68 persen, angka ini memberikan pandangan bahwa pejabat senior amat kondusif memberikan respon terhadap bahasa Inggris untuk dikembangkan di dua kampus.

Kemudian, dapat pula ditemukan jawaban indikator sikap suka/sikap setuju (S) terhadap bahasa inggris bagi pejabat senior di Universitas Khairun dan Universitas Muhammadiyah Maluku Utara, sebagaimana pada tabel.3, dan tabel.4.

Tabel 3. Sikap Suka/Sikap Setuju (S)

Pejabat Senior Unkhair dan UMMU Terhadap Bahasa Inggris

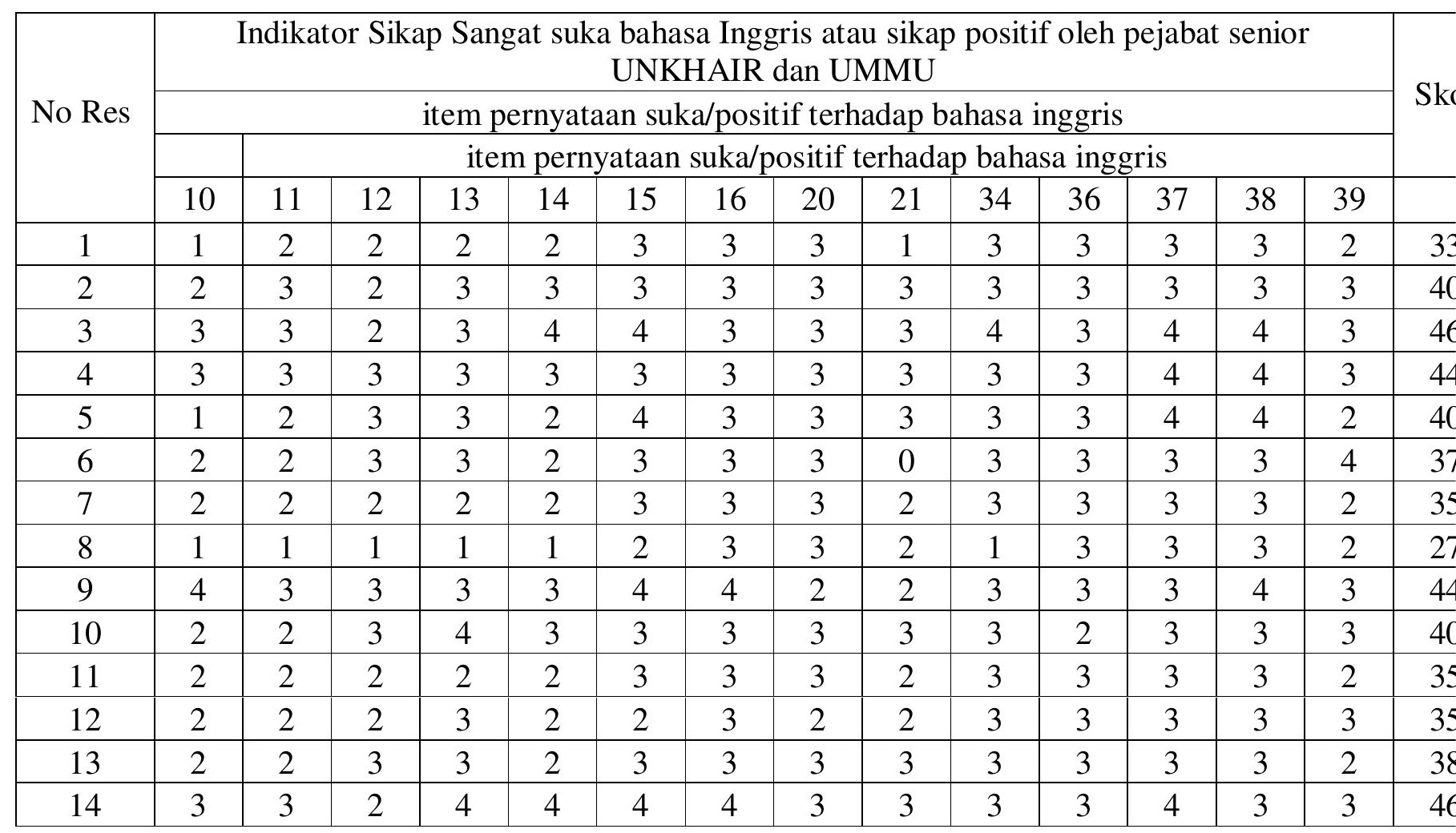




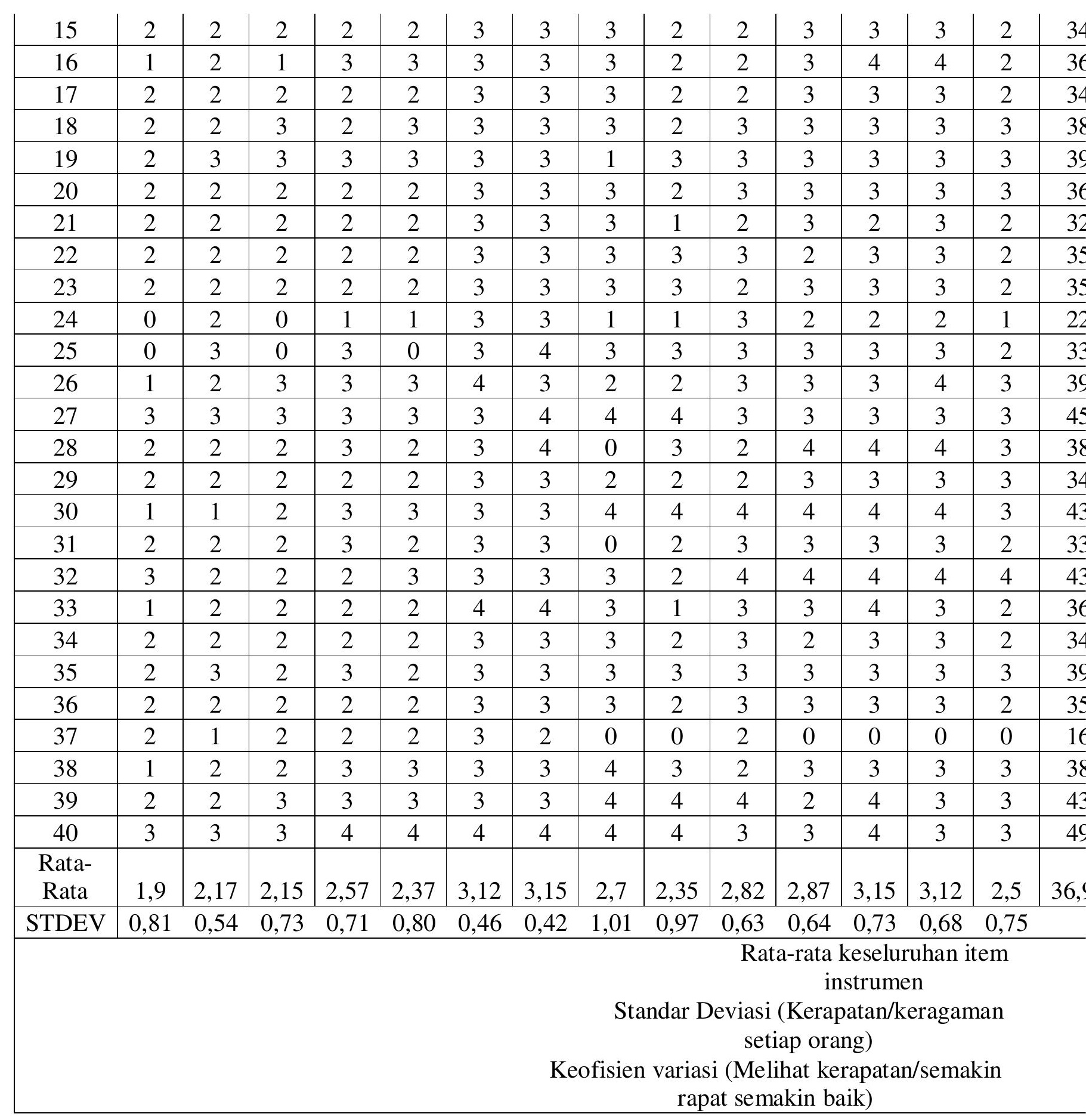

Pada tabel.3, di atas dapat diketahui bahwa rata-rata jawaban pejabat senior di Universitas Khairun dan Universitas Muhammadiyah pada indikator sikap suka terhadap bahasa inggris berada pada rata-rata keseluruhan item yakni 66,0 persen dengan standar deviasi jawaban atau tingkat keseragaman jawaban berada pada angka 6,16, dan keofisien variasi atau kerapatan jawaban para pejabat senior berada pada angka 10,70 .

Data tersebut di atas menunjukan bahwa sikap suka bahasa inggris oleh pejabat senior di Universitas Khairun dan Universitas Muhammadiyah Maluku 
Utara berada pada kategori amat tidak kondusif untuk setiap item yang diberikan. Sehingga, sangat berpeluang tidak peduli terhadap perkembangan bahasa Inggris untuk menjadi branding topik di ruang-ruang kampus. Ini pun sangat jelas terbaca pada tabel.4, bahwa penempatan posisi jabatan di dua kampus tersebut tidak menjadikan bahasa inggris menjadi persyaratan utama. Sebagaimana terdapat pada tabel.4, berikut.

Tabel 4. Sikap Suka Bahasa Inggris untuk persyaratan jabatan Unkhair dan UMMU

\begin{tabular}{|c|c|c|c|c|c|c|c|c|c|c|c|}
\hline \multirow[t]{2}{*}{$\begin{array}{l}\text { No } \\
\text { Resp }\end{array}$} & \multicolumn{9}{|c|}{$\begin{array}{c}\text { Indikator sikap suka bahasa inggris untuk persyaratan jabatan } \\
\text { pejabat } \\
\text { di Universitas Khairun dan Universitas Muhammadiyah } \\
\text { item pernyataan suka (jawaban positif) terhadap bahasa inggris } \\
\text { untuk jabatan }\end{array}$} & \multirow[t]{2}{*}{ Skor } & \multirow[t]{2}{*}{$\begin{array}{c}\text { Persen } \\
\%\end{array}$} \\
\hline & 22 & 23 & 24 & 25 & 26 & 27 & 33 & 35 & 40 & & \\
\hline 1 & 3 & 3 & 3 & 2 & 3 & 3 & 3 & 2 & 2 & 24 & 66,6 \\
\hline 2 & 2 & 3 & 3 & 3 & 3 & 3 & 3 & 3 & 3 & 26 & 72,2 \\
\hline 3 & 4 & 4 & 4 & 2 & 3 & 4 & 3 & 3 & 4 & 31 & 86,1 \\
\hline 4 & 3 & 3 & 3 & 3 & 3 & 3 & 3 & 3 & 3 & 27 & 75 \\
\hline 5 & 2 & 2 & 3 & 1 & 2 & 3 & 3 & 2 & 3 & 21 & 58,3 \\
\hline 6 & 2 & 3 & 3 & 3 & 0 & 3 & 4 & 2 & 2 & 22 & 61,1 \\
\hline 7 & 2 & 3 & 3 & 3 & 2 & 3 & 3 & 2 & 2 & 23 & 63,8 \\
\hline 8 & 1 & 1 & 1 & 2 & 2 & 3 & 3 & 2 & 1 & 16 & 44,4 \\
\hline 9 & 2 & 3 & 2 & 3 & 3 & 4 & 3 & 2 & 3 & 25 & 69,4 \\
\hline 10 & 2 & 3 & 3 & 3 & 3 & 4 & 3 & 3 & 3 & 27 & 75 \\
\hline 11 & 2 & 3 & 3 & 2 & 4 & 3 & 3 & 2 & 2 & 24 & 66,6 \\
\hline 12 & 2 & 2 & 2 & 2 & 3 & 3 & 0 & 3 & 2 & 19 & 52,7 \\
\hline 13 & 2 & 2 & 2 & 2 & 2 & 3 & 3 & 2 & 2 & 20 & 55,5 \\
\hline 14 & 4 & 4 & 4 & 3 & 3 & 3 & 3 & 3 & 3 & 30 & 83,3 \\
\hline 15 & 2 & 3 & 2 & 2 & 2 & 3 & 3 & 2 & 2 & 21 & 58,3 \\
\hline 16 & 3 & 2 & 3 & 2 & 2 & 3 & 3 & 3 & 2 & 23 & 63,8 \\
\hline 17 & 2 & 2 & 3 & 3 & 2 & 3 & 3 & 2 & 2 & 22 & 61,1 \\
\hline 18 & 3 & 3 & 4 & 3 & 3 & 3 & 3 & 2 & 3 & 27 & 75 \\
\hline 19 & 3 & 3 & 3 & 3 & 0 & 3 & 3 & 3 & 3 & 24 & 66,6 \\
\hline 20 & 2 & 2 & 2 & 2 & 2 & 3 & 3 & 3 & 3 & 22 & 61,1 \\
\hline 21 & 1 & 1 & 1 & 1 & 1 & 3 & 2 & 2 & 2 & 14 & 38,8 \\
\hline 22 & 2 & 2 & 2 & 2 & 2 & 3 & 3 & 3 & 3 & 22 & 61,1 \\
\hline 23 & 3 & 3 & 3 & 3 & 3 & 3 & 3 & 2 & 2 & 25 & 69,4 \\
\hline 24 & 4 & 3 & 4 & 2 & 4 & 4 & 3 & 3 & 2 & 29 & 80,5 \\
\hline 25 & 3 & 3 & 3 & 2 & 0 & 3 & 3 & 0 & 3 & 20 & 55,5 \\
\hline 26 & 3 & 3 & 3 & 3 & 3 & 3 & 4 & 2 & 4 & 28 & 77,7 \\
\hline 27 & 4 & 3 & 3 & 3 & 3 & 3 & 3 & 3 & 3 & 28 & 77,7 \\
\hline 28 & 3 & 3 & 3 & 4 & 3 & 4 & 4 & 3 & 2 & 29 & 80,5 \\
\hline 29 & 3 & 3 & 3 & 3 & 3 & 3 & 2 & 3 & 2 & 25 & 69,4 \\
\hline
\end{tabular}




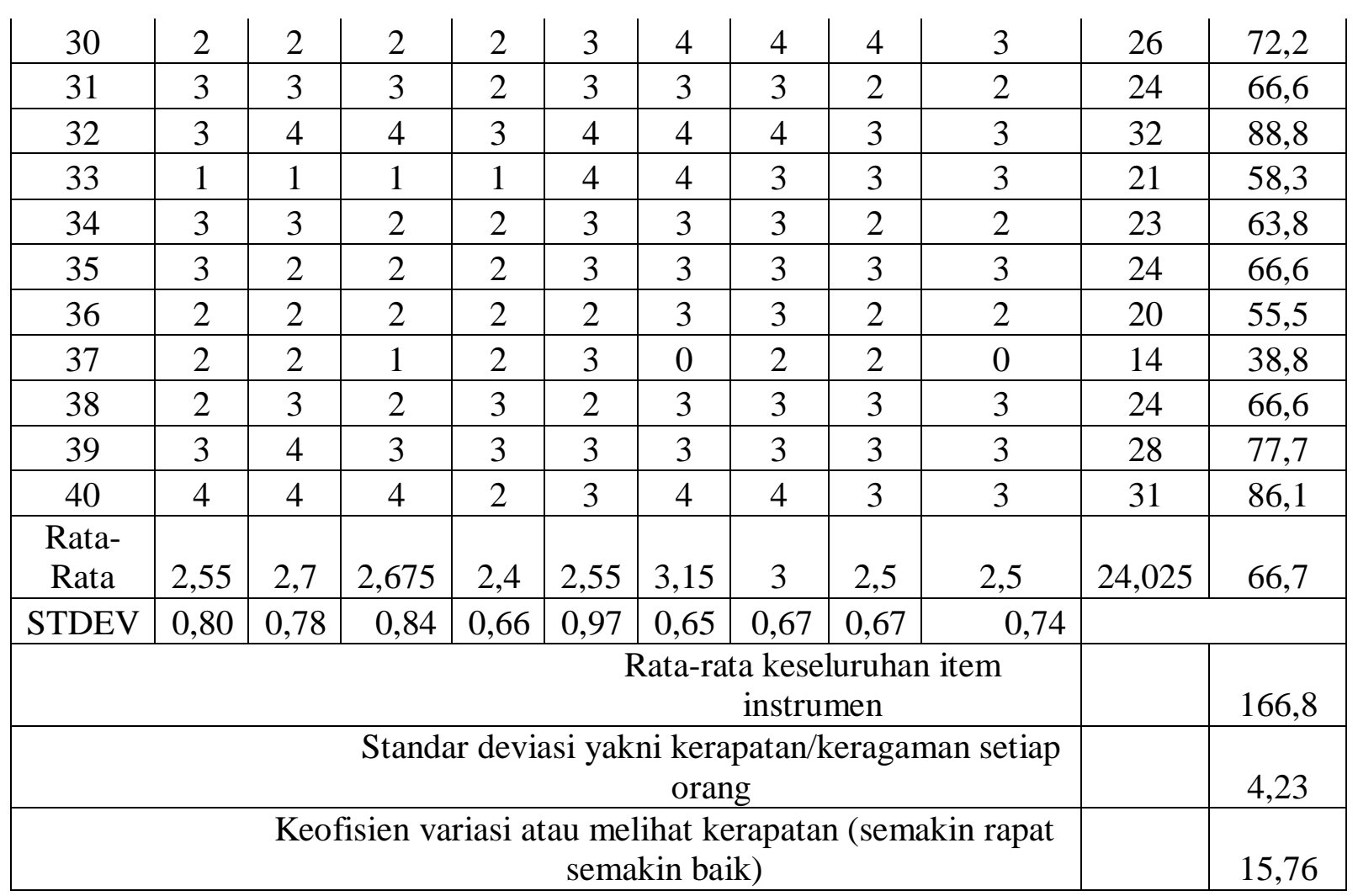

Di dalam tabel 4, di atas rata-rata jawaban pejabat senior baik di Universitas Khairun dan Universitas Muhammadiyah Maluku Utara berada pada angka 2,5 sampai dengan 3, dengan standar deviasi setiap item 0,65 sampai 0,80 atau secara keseluruhan item 166,8 skor. Keofisien variasi jawaban yang diberikan 15, 76 persen. Dalam hal ini sikap pejabat senior hanya respon pada setiap item tidak setuju dan setuju saja terhadap bahasa Inggris. Kemudian, sikap tidak suka/ sikap tidak setuju (TS) dan Sangat Tidak Setuju (STS) oleh pejabat senior terhadap bahasa Inggris terungkap pada data yang dianalisis yakni tergambar di tabel 5, sebagai berikut.

Tabel.5. Sikap tidak suka terhadap bahasa inggris pejabat senior Unkhair dan UMMU

\begin{tabular}{|c|c|c|c|c|c|c|c|}
\hline \multirow[t]{2}{*}{ No. Resp } & \multicolumn{5}{|c|}{$\begin{array}{l}\text { indikator tidak suka terhadap } \\
\text { bahasa Inggris } \\
\text { oleh pejabat senior Univ.Khairun dan } \\
\text { Univ.Muhammadiyah Maluku Utara } \\
\text { Item pernyataan tidak suka (jawaban negatif) } \\
\text { terhadap bahasa inggris }\end{array}$} & \multirow[t]{2}{*}{ Skor } & \multirow[t]{2}{*}{ Persen $\%$} \\
\hline & 8 & 9 & 17 & 18 & 19 & & \\
\hline 1 & 2 & 2 & 2 & 3 & 3 & 12 & 60 \\
\hline 2 & 2 & 2 & 2 & 2 & 2 & 10 & 50 \\
\hline 3 & 1 & 1 & 2 & 1 & 1 & 6 & 30 \\
\hline 4 & 2 & 2 & 2 & 2 & 2 & 10 & 50 \\
\hline
\end{tabular}




\begin{tabular}{|c|c|c|c|c|c|c|c|}
\hline 5 & 2 & 2 & 1 & 0 & 0 & 5 & 25 \\
\hline 6 & 2 & 2 & 2 & 2 & 2 & 10 & 50 \\
\hline 7 & 2 & 2 & 2 & 3 & 3 & 12 & 60 \\
\hline 8 & 2 & 2 & 2 & 4 & 3 & 13 & 65 \\
\hline 9 & 1 & 1 & 1 & 2 & 2 & 7 & 35 \\
\hline 10 & 0 & 2 & 2 & 1 & 2 & 7 & 35 \\
\hline 11 & 2 & 2 & 2 & 3 & 2 & 11 & 55 \\
\hline 12 & 2 & 2 & 2 & 2 & 2 & 10 & 50 \\
\hline 13 & 2 & 2 & 2 & 2 & 2 & 10 & 50 \\
\hline 14 & 1 & 2 & 2 & 2 & 2 & 9 & 45 \\
\hline 15 & 0 & 0 & 2 & 2 & 2 & 6 & 30 \\
\hline 16 & 1 & 1 & 3 & 3 & 2 & 10 & 50 \\
\hline 17 & 2 & 2 & 2 & 3 & 3 & 12 & 60 \\
\hline 18 & 1 & 1 & 2 & 2 & 2 & 8 & 40 \\
\hline 19 & 1 & 2 & 3 & 2 & 1 & 9 & 45 \\
\hline 20 & 2 & 2 & 2 & 2 & 3 & 11 & 55 \\
\hline 21 & 2 & 2 & 2 & 3 & 3 & 12 & 60 \\
\hline 22 & 2 & 2 & 2 & 2 & 2 & 10 & 50 \\
\hline 23 & 2 & 2 & 3 & 2 & 3 & 12 & 60 \\
\hline 24 & 1 & 0 & 0 & 3 & 0 & 4 & 20 \\
\hline 25 & 1 & 1 & 2 & 3 & 3 & 10 & 50 \\
\hline 26 & 1 & 1 & 1 & 3 & 3 & 9 & 45 \\
\hline 27 & 3 & 3 & 0 & 4 & 3 & 13 & 65 \\
\hline 28 & 2 & 2 & 2 & 3 & 3 & 12 & 60 \\
\hline 29 & 2 & 2 & 2 & 2 & 2 & 10 & 50 \\
\hline 30 & 1 & 1 & 2 & 4 & 4 & 12 & 60 \\
\hline 31 & 2 & 2 & 2 & 2 & 2 & 10 & 50 \\
\hline 32 & 2 & 1 & 2 & 3 & 3 & 11 & 55 \\
\hline 33 & 1 & 1 & 1 & 3 & 3 & 9 & 45 \\
\hline 34 & 2 & 2 & 2 & 2 & 2 & 10 & 50 \\
\hline 35 & 2 & 2 & 2 & 2 & 2 & 10 & 50 \\
\hline 36 & 2 & 2 & 2 & 3 & 2 & 11 & 55 \\
\hline 37 & 2 & 2 & 2 & 2 & 1 & 9 & 45 \\
\hline 38 & 2 & 2 & 2 & 2 & 2 & 10 & 50 \\
\hline 39 & 2 & 2 & 2 & 2 & 2 & 10 & 50 \\
\hline 40 & 2 & 2 & 2 & 3 & 3 & 12 & 60 \\
\hline Rata-Rata & 1,65 & 1,7 & 1,875 & 2,4 & 2,225 & 9,85 & 49,25 \\
\hline STDEV & 0,62 & 0,60 & 0,60 & 0,81 & 0,83 & 2,10 & \\
\hline \multicolumn{7}{|c|}{ Rata-rata keseluruhan item instrumen } & 123,125 \\
\hline \multicolumn{7}{|c|}{ Standar Deviasi } & 2,080 \\
\hline \multicolumn{7}{|c|}{ Koefesian variasi } & 23,67 \\
\hline
\end{tabular}


Pada tabel 5, menunjukan bahwa rata-rata keseluruhan item jawaban pejabat senior kurang suka terhadap bahasa inggris berada pada angka 1,65 sampai 2,225, dengan standar deviasi 2,080, serta keofesien variasi 23,67. Angkaangka tersebut menunjukan bahwa sikap pejabat senior pada kriteria tidak suka terhadap bahasa Inggris berada pada kelas amat tidak kondusif.

Analisis tersebut di atas semua menggunakan metode manual dengan program execel dan pada penelitian ini juga menggunakan metode analisis menggunakan program WINKS SDA 7 dengan hasil menunjukan bahwa rata-rata 2,50, dengan standar deviasi 0,74, serta keofisien 0,300. Angka-angka ini kalau dikonversikan pada kriteria sikap bahasa maka sikap pejabat senior di Universitas Khairun dan Universitas Muhammadiyah Maluku Utara berada pada rata-rata kondusif dengan persentase $0,5 \%$. Berikut hasil hitung program WINKS SDA 7.

\begin{tabular}{|lr|}
\hline & Descriptive Statistics \\
$\mathrm{N} \quad=40$ & Missing or Deleted $=0$ \\
Mean $=2,50$ & St. Dev $(\mathrm{n}-1)=0,75107$ \\
Median $=3,00$ & St. Dev $(\mathrm{n})=0,74162$ \\
Minimum $=0,00$ & S.E.M. $=0,11875$ \\
Maximum $=4,00$ & Variance $=0,5641$ \\
Sum $=100,00$ & Coef. Var. $=0,30043$ \\
Skewness $=-, 764$ & Kurtosis $=2,065$ \\
\hline
\end{tabular}

Analisis program WINKS SDA 7 di atas selaras dengan perhitungan manual menggunakan program excel dengan rata-rata keseluruhan item jawaban 2,50, dengan standar deviasi 0,74 dan keofisien variasi 0,300. Data tersebut sangat mendukung bahwa sikap pejabat senior di Universitas Khairun dan Universitas Muhammadiyah Maluku Utara berada pada rata-rata tidak kondusif atau cukup dalam rumusan kriteria sikap bahasa terhadap bahasa Inggris.

\section{KESIMPULAN DAN REKOMENDASI}

\section{Kesimpulan}

Sikap pejabat senior di Universitas Khairun dan Universitas Muhammadiyah Maluku Utara terhadap bahasa Inggris menunjukan frekuensi pada angka Sangat Setuju 0,12 \%, Setuju 0,49\%, Netral 0,03\%, tidak setuju 0,31 $\%$, Sangat tidak setuju 0,06\%. Angka-angka persen tersebut menunjukan bahwa sikap pejabat senior di Universitas Khairun dan Universitas Muhammadiyah Maluku Utara terhadap bahasa inggris berada pada kategori kondusif atau kriteria cukup pada sikap bahasa.

Berdasarkan analisis program WINKS SDA 7 menunjukan bahwa rata-rata 2,50, dengan standar deviasi 0,74, serta keofisien variasi 0,300. Angka-angka ini kalau dikonversikan pada kriteria sikap bahasa maka sikap pejabat senior di 
Universitas Khairun dan Universitas Muhammadiyah Maluku Utara berada pada rata-rata kondusif dengan persentase 0,5\%. Analisis program WINKS SDA 7 selaras dengan perhitungan manual menggunakan program excel yakni rata-rata keseluruhan item jawaban 2,61, dengan standar deviasi 0,35, dan keofisien variasi 292,9, sehingga dapat dipastikan sikap pejabat senior berada pada posisi cukup dan kondusif di Universitas Khairun dan Universitas Muhammadiyah Maluku Utara.

\section{Rekomendasi}

Kalau Universitas Khairun dan Universitas Muhammadiyah Maluku Utara ingin menuju ke kampus berskala internasional maka bahasa Inggris harus menjadi branding akademik dalam kegiatan kemahasiswa maupun pejabat di kampus. Oleh karena itu, harus ada branding kampus berskala internasional dengan membuat peraturan akademik secara ketat untuk pentingnya bahasa inggris dipelajari dan dipraktekan pada ruang-ruang diskusi maupun perkuliahan serta prasyarat kelulusan maupun promosi jabatan di kampus.

\section{DAFTAR PUSTAKA}

Arasuli, 2004. Sikap Pejabat Sikap Pejabat Senior di Kalangan Pemerintah dan Bisnis di Kota Bengkulu terhadap Bahasa Inggris dalam menghadapi era globalisasi dan otonomi daerah. Jurnal: Wacana Universitas Bengkulu, tahun 2006, volume 9, nomor 1, hlm 17-29.

Azwar.1995. Sikap Manusia: Teori dan Pengukurannya. Yogyakarta: Liberty.

Asrul, 2008. The Predictability of Student's English Acheivement From Their Attitude Toward English Learning and Leraning Motivation. Thesis: Islamic University of Malang.

Gardner, R.C. 1985. Social Psychology and Second Language Learning. The Role of Attittudes and Motivation. USA: British Library Cataloguing in Publication Data.

Kalfira, Devi., dkk. 2013. Sikap bahasa siswa terhadap bahasa Indonesia: Studi kasus di SMA Negeri 1 Singaraja. e-Journal: Program Pascasarjana Universitas Pendidikan Ganesha Program Studi Pendidikan Bahasa dan Sastra Indonesia, volume 2 tahun 2013.

Mahsun. 2005. Metode Penelitian Bahasa. Jakarta: Rajawali Pers.

Muhammad.2011. Metode Penelitian Bahasa. Jogjakarta: AR-Ruzz Media

Pantow, B.S. Johanna \& dkk. 2008. Pendidikan Bahasa Inggris. Jakarta. Penerbit: Universitas Terbuka.

Pangaribun, Tagor.2008.Paradigma Bahasa.Yogyakarta: Graha Ilmu.

Sudaryanto.1993. Metode dan Aneka Teknik Analisis Bahasa. Pengantar Penelitian Wahana Kebudayaan Secara Linguistis. Yogyakarta: Duta Wacana University Press

Saraswati, Widya. 2002. Mengembangkan Kompetensi di Era Globalisasi. Sinar Harapan, 4 Mei.

Suwarno, Bambang, Dendi Kartini, dan Darnoko. 1999. Korelasi antara sikap terhadap bahasa Inggris dengan prestasi belajar bahasa Inggris pada siswa SMU Muhammadiyah 4 Bengkulu tahun ajaran 1997/1998. Jurnal: 
Penelitian Penelitian Lembaga Universitas Bengkulu, V/133, Desember 1998, hal 60-62.

Sugiyono. 2008. Metode Penelitian Kuantitatif, Kualitatif dan R \& D. Bandung. Penerbit: Alfabeta Penerbit.

Sugioyono.2010.Memahami Penelitian Kualitatif. Bandung: Alfabeta,cv.

Iwa Sobara, I., dkk. 2013. Sikap bahasa Mahasiswa laki-laki dan Perempuan di Jurusan Sastra Jerman Universitas Negeri Malang. Jurnal: Bahasa dan Seni Universitas Negeri Malang. Tahun 41. nomor 1. hlm. 93-105.

Wishon, E. G \& et.al. 1980. Let's Write English Revised Edition. USA: Litton Education Publishing, Inc. 
